Stealing in by the Window: Ojibway-Government Relations in the Quetico

$$
\text { by }
$$

\title{
Carol Hodgson
}

\author{
A thesis submitted to the Faculty of \\ Graduate Studies and Research in partial fulfilment \\ of the requirements for the degree of \\ Master of Arts \\ in Canadian Studies
}

\author{
Carleton University \\ OTTAWA, Ontario \\ August 7, 2003 \\ 2003, Carol Hodgson
}




\author{
National Library \\ of Canada \\ Acquisitions and \\ Bibliographic Services \\ 395 Wellington Street \\ Ottawa ON K1A ON4 \\ Canada
}

Bibliothèque nationale

du Canada

Acquisisitons et services bibliographiques

395 , rue Wellington Ottawa ON K1A 0N4 Canada
Your file Votre référence ISBN: 0-612-89047-3 Our file Notre référence ISBN: 0-612-89047-3
The author has granted a nonexclusive licence allowing the National Library of Canada to reproduce, loan, distribute or sell copies of this thesis in microform, paper or electronic formats.

The author retains ownership of the copyright in this thesis. Neither the thesis nor substantial extracts from it may be printed or otherwise reproduced without the author's permission.
L'auteur a accordé une licence non exclusive permettant à la Bibliothèque nationale du Canada de reproduire, prêter, distribuer ou vendre des copies de cette thèse sous la forme de microfiche/film, de reproduction sur papier ou sur format électronique.

L'auteur conserve la propriété du droit d'auteur qui protège cette thèse. $\mathrm{Ni}$ la thèse ni des extraits substantiels de celle-ci ne doivent être imprimés ou aturement reproduits sans son autorisation.
In compliance with the Canadian Privacy Act some supporting forms may have been removed from this dissertation.

While these forms may be included in the document page count, their removal does not represent any loss of content from the dissertation.
Conformément à la loi canadienne sur la protection de la vie privée, quelques formulaires secondaires ont été enlevés de ce manuscrit.

Bien que ces formulaires aient inclus dans la pagination, il n'y aura aucun contenu manquant. 
The reason why we stop you is because we think you do not tell us why you want to go that way, and what you want to do with those paths. You say that all the white men we have seen belong to one party, and yet they go by three different roads, why is that? Do they want to see the Indian's land? Remember, if the white man comes to the Indian's house, he must walk through the door, and not steal in by the window.

Unnamed Ojibway chief in Henry Youle Hind, Narrative of the Red River Exploring Expedition of 1857. 


\begin{abstract}
This thesis is a study of the political strategies used by the government of Canada, the government of Ontario and the Ojibway of Treaty \#3 in negotiations over the regulation, use and occupation of the Quetico region of north-western Ontario. Postcolonial theory is used to identify and question the development of a colonial discourse and Ojibway forms of resistance. The interactions of two levels of government with distinct and sometimes contrary land values have complicated this process. Resistance by Ojibway leaders is clearly evident throughout the period, although strategic approaches have varied. The strategies of all parties are compared using frame analysis, as developed by Erving Goffman and David Snow. The thesis concludes that suppression has played a vital role in the development of this colonial discourse, and that successful strategies of resistance have often targeted the values underlying colonialism to create space in which to negotiate for change.
\end{abstract}




\section{CONTENTS}

LIST OF ABBREVIATIONS $\ldots \ldots \ldots \ldots \ldots \ldots \ldots \ldots \ldots \ldots \ldots$ vi

MAP OF THE QUETICO REGION ................... vii

\section{Chapter}

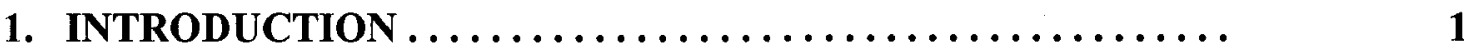

Colonialism/Postcolonialism

Introduction to frame analysis

Frame alignment - bridging, amplification, extension and transformation

Historical sources

Aboriginal history

Studies of Aboriginal politics and resistance

History of government policy

Some notes on terminology

2. CONTESTED LAND: THE POLITICAL HISTORY OF THE

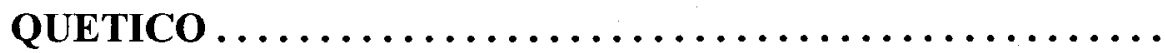

"A rich Country": The treaty-making era

Colonialism bears down: 1873-1909

The changing meaning of "wilderness": 1909-1930

Survival strategies: $1930-1970$

Resurgence: 1971-present 


\section{Chapter}

3. "WE HAVE SUCH LITTLE VOICE: OJIBWAY POLITICAL STRATEGIES $\ldots \ldots \ldots \ldots \ldots \ldots \ldots \ldots \ldots \ldots \ldots \ldots \ldots$

"We do not want the white man"

Communications break down

"Sold down the river"

"Free and unfettered access"

\section{4. "AN ORDERLY WHITE PRESENCE": GOVERNMENT}

STRATEGIES ...........................

The development of Indian policy in Canada

Indian policy in the Quetico

A "powerful Indian community"

"Simply moral and no more"

"The Indians would not be interfered with"

Federal inaction

A "really exclusive marketable commodity"

Federal initiatives in the Quetico 1948-1970

"Buried under English words"

The 1991 Ontario apology

Negotiating self-governance 


\section{Chapter}

5. COnCLUSIONS $\ldots \ldots \ldots \ldots \ldots \ldots \ldots \ldots \ldots \ldots \ldots \ldots$

Sites of resistance

Ojibway leadership and direct confrontation

Expressing the value of Ojibway culture

Contesting political representivity

Suppression and the colonial discourse

Continuity and change

SOURCES CONSULTED 


\section{LIST OF ABBREVIATIONS}

$\begin{array}{ll}\text { AFN } & \text { Assembly of First Nations } \\ \text { AWL } & \text { Algonquin Wildlands League } \\ \text { FNGA } & \text { First Nations Governance Act } \\ \text { HBC } & \text { Hudson's Bay Company } \\ \text { INAC } & \text { Indian and Northern Affairs Canada } \\ \text { LLCFN } & \text { Lac La Croix First Nation } \\ \text { MP } & \text { Member of Parliament } \\ \text { MLA } & \text { Member of Legislative Assembly } \\ \text { NAC } & \text { National Archives of Canada } \\ \text { QPP } & \text { Quetico Provincial Park } \\ \text { TARR } & \text { Treaty and Aboriginal Rights Research }\end{array}$




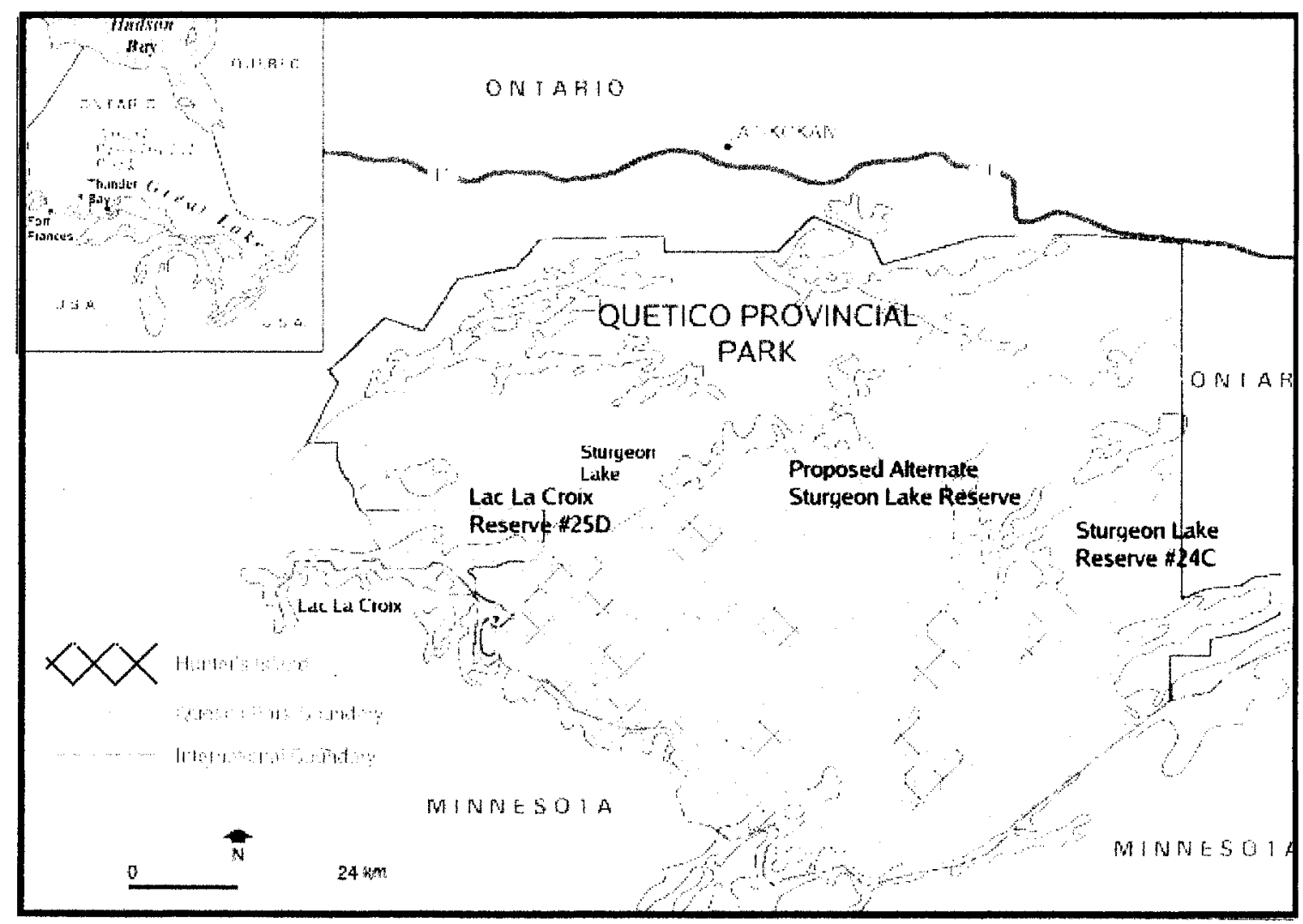

Figure 1. Map of the Quetico Region. The fourteen Ojibway registered traplines are located in the northern part of the park, outside of Hunter's Island. The area of Hunter's Island was also excluded from timber licensing when licenses were granted in the Quetico region.

Base map from:

Quetico Foundation, www.queticofoundation.org/maps/park map.gif, 2003

Additional data from:

Pierrette Désy and Frédéric Castel, Native Reserves in Eastern Canada to 1900 ed. R. Louis Gentilcore (Toronto: University of Toronto Press, 1993); Gerald Killan, Protected Places: a History of Ontario's Provincial Parks System (Toronto: Dundurn Press, 1993), 94; Quetico Provincial Park Master Plan. Toronto: Ministry of Natural Resources, 1977; Fort Frances Agency, Sturgeon Lake Band, October 27, 1894, RG 10 Vol 7537 File 27, 124-9. 


\section{CHAPTER ONE}

\section{INTRODUCTION}

In this study, I will present an analysis of the political strategies used in land negotiations between the federal and provincial governments and the Ojibway of the Quetico region of northwestern Ontario. This case study is an example of power relations between First Nations and governments in Canada, situated within the postcolonial discourse. It will address the relationship between language and power in First Nations-government relations and identify sites of resistance to colonialism.

The Quetico is a region of forests, lakes and swamps that begins approximately 200 kilometres west of Thunder Bay, Ontario. It is part of the traditional territory of a group of Ojibway now known as the Ojibway of Treaty \#3. The Ojibway of the Quetico region include members of the Lac La Croix First Nation and the former Sturgeon Lake Band, whose reserve is now subsumed by Quetico Provincial Park. In addition, the territory has been used by the members of the Rainy River First Nation, the Lac des Mille Lacs First Nation and the Seine River First Nation. ${ }^{1}$ Altogether there are twenty-eight First Nations represented by the Treaty \#3 Grand Council, including twenty-six in Ontario and two in Manitoba. ${ }^{2}$

\footnotetext{
Looking at Figure 2, Lac La Croix can be seen in the south-east corner.The Rainy River flows west from Lac La Croix to Rainy Lake, where the reserves of Couchiching and Stanjikoming are identified. Sturgeon Lake is slightly north-east of Lac La Croix, as seen in Figure 1.

2 See map next page for a complete list of First Nation names.
} 


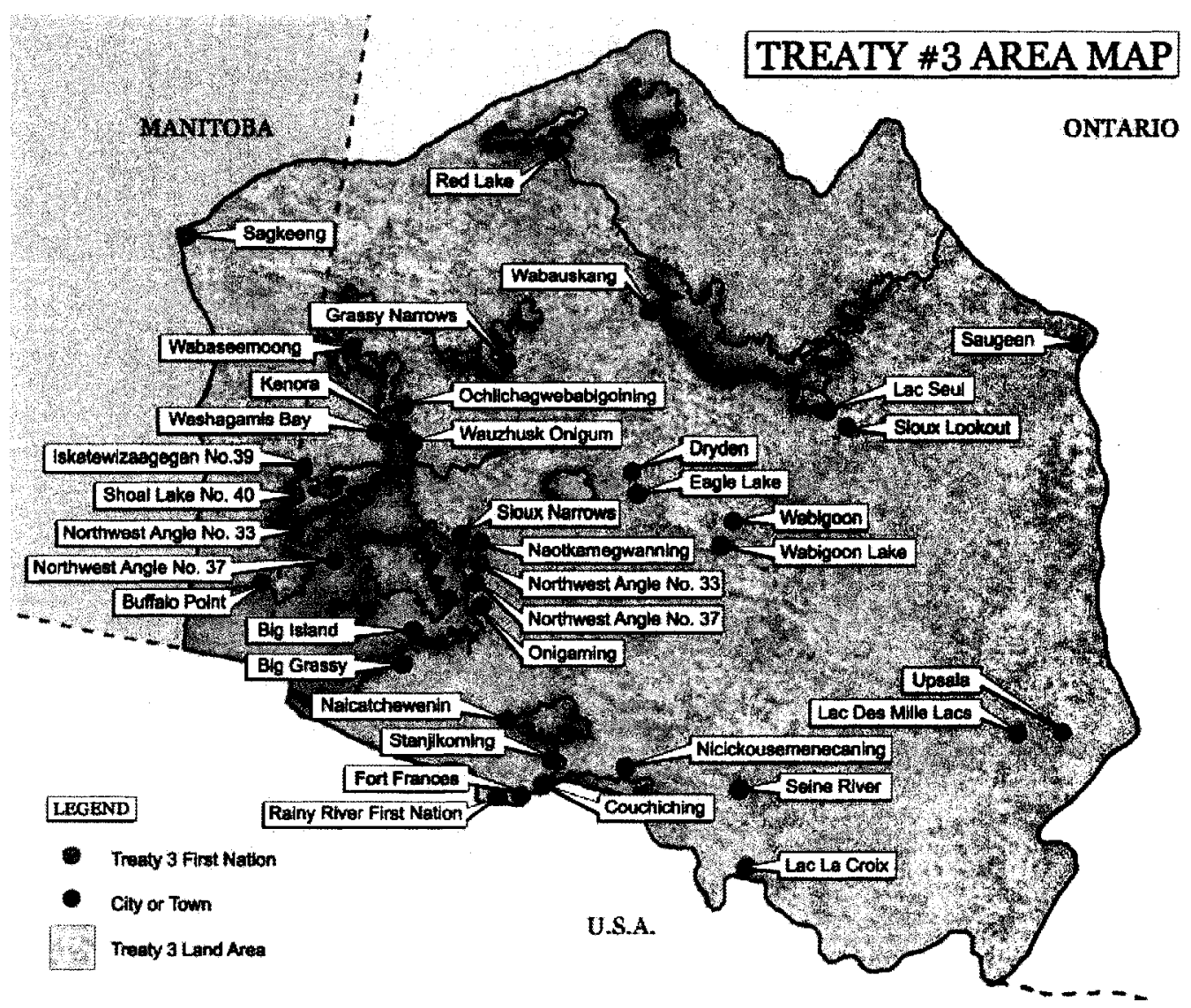

Figure 2. Reprinted from Grand Council Treaty \#3, accessed June 14, 2003; available from http://www.treaty3.ca/pages/map.html.

The area as a whole is sometimes called the Northwest Angle, and there are also several points on the Lake of the Woods that are known by this name, including one on the American side of the border. The grand council structure pre-dates the treaty, which was signed in 1873 . Although the treaty was negotiated with the federal government, the Ontario government, in particular the Ministry of Lands and Forests, has also played a major role in the politics of the region.

I suggest that the Ojibway have needed to develop carefully framed statements of their needs to address these two different government audiences, and I will outline 
changes and continuities in their strategic approaches and those of both levels of government. I will explore the various forms which anti-colonial resistance has taken over a period of one hundred and fifty years, and I will demonstrate that such resistance has played a role in determining the history and present form of the Quetico. I will also discuss the evolution of the colonial discourse as it has manifested in this place and time.

I will first set out a political history of the Quetico, emphasizing the interactions and negotiations between the Ojibway and government representatives. I will then use this as a background against which to discuss a selection of political speeches and written texts in detail. Ojibway texts will be presented and analyzed in Chapter Three, followed by a discussion of government texts in Chapter Four. These chapters will follow the chronology laid out in Chapter Two and will examine the narrative strategies used by Ojibway and government speakers in different historical contexts. Keeping in mind that Ojibway negotiations over land and governance predate colonialism and are not a product of it, I will present the Ojibway texts first. I cannot enter into a discussion of the nature of that pre-colonial discourse, since all available texts are of course products of the colonial discourse. My analysis compares examples of leadership strategies from the treaty period on.

\section{Colonialism/Postcolonialism}

Critical analysis of the colonial discourse emerged as a significant field of study in the 1970's. In this context, the term 'discourse' refers to patterns of meaning created through language, and 'colonial discourse' refers to the ways discursive practices create and maintain assymetrical relations between the colonizers and the colonized. In general, 
critics have found that colonial discourses perpetuate the assumptions that rule over indigenous peoples is just and that subservience to colonial authority is acceptable and appropriate. $^{3}$

Postcolonial theory developed in tandem with the colonial critique.

Postcolonialists use tools such as discourse analysis to explore resistance to colonialism and to foreground alternative values and ideas. The work of the Kenyan writer Ngugi wa Thiong'o has exerted a major influence on the development of postcolonial theory. In both fiction and essays, Ngugi explored questions of anti-colonial resistance, the threat of neo-colonialism, and the need for "decolonizing the mind."4 Arguing that indigenous languages and cultures are attacked and devalued by colonialism, he called for the use of indigenous languages as a means of contesting the colonial discourse. Ngugi argued that contemporary indigenous peoples could use language to keep alive a spirit of resistance and foreground the importance of indigenous cultures. ${ }^{5}$

Many critics of the colonial discourse argue that narrative strategies are fundamental to the success of the colonial enterprise. Colonial discourses present social and economic relations in such a way that some actions are perceived as possible while others are not. However, the Italian political theorist Antonio Gramsci (1891-1937) argued that state control is always fragile and contested, requiring constant reinforcement to ensure compliance. This reinforcement takes both practical and symbolic forms. On the practical level, governance requires the monopolization of force, for example, to prevent armed insurrection. On the symbolic level, state authority is maintained through

\footnotetext{
John McLeod Beginning Postcolonialism (Manchester: Manchester University Press, 2000), 18

4 Ngugi wa Thiong'o, Decolonizing the Mind: The Politics of Language in African Literature (London: James Currey, 1986).

5 McLeod, 127
} 
the development of symbolism, from the creation of a national history to the erection of government buildings and monuments. Governance and authority interact to maintain the state. ${ }^{6}$

Symbols of state power promote the idea that the existence of the state has a natural or inevitable quality; they naturalize the state and its governance practices. Colonial discourses use symbolism to naturalize incursion and colonization. To accomplish this, they must suppress images of indigenous cultures, resistance to colonialism and the often violent response of the state. This can be done either by straightforwardly eliminating references to indigenous peoples, or by creating an ideology that suggests that colonization was natural and perhaps even beneficial to indigenous peoples. ${ }^{7}$ Conversely, by questioning or denaturalizing the symbolic authority of the state as developed in the colonial discourse, the fragile nature of the state can be exposed, opening the door to the consideration of alternative models of governance.

Studies of resistance have drawn on this concept to analyze the specific situations in which resistance has been possible, and to study the strategies employed to exploit the vulnerabilities of state power. James R. Scott's Weapons of the Weak, a detailed study of "everyday forms of peasant resistance" in Malaysia, has been highly influential in this field. It identified many subtle, indirect forms of resistance, such as sloppiness and footdragging in agricultural work. Scott made the case that these forms emerge when the

\footnotetext{
${ }^{6}$ Thomas Blom Hansen and Finn Stepputat, States of Imagination: Ethnographic Explorations of the Postcolonial State (Durham: Duke University Press, 2001), 7-9.

${ }^{7}$ This is discussed in much greater detail in James (Sákéj) Youngblood Henderson, "Postcolonial Ghost Dancing: Diagnosing European Colonialism," in Reclaiming Indigenous Voice and Vision, ed. Marie Battiste (Vancouver: University of British Columbia Press, 2002), passim 57-76.
} 
resisters have minimal power and resources, making overt resistance highly risky. ${ }^{8}$ Scott also argued that resistance cannot be isolated from self-interest, using historical examples from widely recognized resistance movements such as the Russian Revolution to argue that there are many cases in which self-interest is in fact the starting point of resistance. ${ }^{9}$ It is often through the individual recognition of injustice that the assumptions of colonialism are called into question.

Following upon the work of these writers, literary theorists examining texts produced by colonized peoples began to read them "against the grain," attempting to denaturalize colonial texts and to locate elements of resistance to colonial images and values. ${ }^{10}$ These studies are at the core of the rapidly expanding field of postcolonial theory, which is now used in many disciplines, including anthropology, history and geography. In Canadian Studies, a postcolonial stance can expand our understanding of colonialism and its continuing impacts, providing, among other things, a context for discussing contemporary Aboriginal-government relations. For example, a recent collection of essays, Race, Space and the Law: Unmapping a White Settler Society, ${ }^{\prime \prime}$ examines the ways in which political and social constructions of space have perpetuated racism and colonial values in Canada. Another example, Reclaiming Indigenous Voice and Vision ${ }^{2}$, is a collection of essays produced by delegates to the United Nations Working Group on Indigenous Populations gathered to discuss the potential for cultural restoration in Indigenous communities around the world.

\footnotetext{
${ }^{8}$ James R. Scott, Weapons of the Weak: Everyday Forms of Peasant Resistance (New Haven: Yale University Press, 1985), 299.

9 Ibid., 295-97.

10 Ibid., 24

1 Ed. Sherene Razack (Toronto: Between the Lines, 2002).

${ }^{12}$ Ed. Marie Battiste ( Vancouver: University of British Columbia Press, 2000).
} 
The application of postcolonial theory to a text exposes the relationship between language and power in colonial discourse. Exploring the ways in which the structures and values of a given state have been naturalized opens the door to the consideration of other competing concepts that have been suppressed. Postcolonial analysis is therefore clearly applicable to political narratives, since political texts are in many senses creative constructions, explicitly and consciously developed to convince an audience of the legitimacy of a political idea.

In addition, postcolonial critique offers guidelines for the close examination of vocabulary and syntax. The Empire Writes Back ${ }^{13}$ provides a useful example of this approach to postcolonial studies. Although its authors have been criticized for minimizing differences between colonial experiences and attempting to create "a grand theory of postcolonialism,"14 their analytical techniques are valuable tools for postcolonial discourse analysis. Their discussion of the use of irony to undermine the colonial discourse and the insertion of indigenous language into English texts are particularly useful in this study.

In Canada, as in many other countries with a history of colonialism, it is questionable when, or indeed if, 'the colonial period' has actually ended. In the limited sense of colonialism as the governance and invasive settlement of one country by another, Canada today cannot be described as colonial. At the same time, colonialism as practiced by a capitalist society is based upon the extraction of resources and the attempt to govern indigenous peoples, and in this sense Canada continues to be very much a

13 Bill Ashcroft, Gareth Griffiths, and Helen Tiffin The Empire Writes Back: Theory and Practice in Post-colonial Literatures ( London: Routledge, 1989).

14 Vijay Mishra and Bob Hodge "What is Post(-)colonialism?" in Colonial Discourse and Post-Colonial Theory, ed. Patrick Williams and Laura Chrisman (London: Harvester, 1993) quoted in McLeod, 28. 
colonial society. The term 'internal colonialism' applies to cases in which the asymmetrical arrangement of political and economic relations necessary for colonialism occurs within, rather than across, national borders. ${ }^{15}$ Internal colonialism is therefore the most accurate description of the relationship between Aboriginal people and governments in Canada today, and the colonial discourse necessary to perpetuate it continues.

\section{Introduction to frame analysis}

Throughout this study, I will use frame analysis as the basic tool to examine the strategies embedded in the political texts under consideration. Developed by the American sociologist Erving Goffman and published in book form in 1974, frame analysis is grounded in the assumption that meaning is culturally produced and regulated through the use of frameworks of interpretation. These frameworks use several mechanisms to confer meaning on an activity or object; these are location, perception, identification and labelling. ${ }^{16}$ At the most basic level, frames allow us to decide which aspects of our experience to include in our "story line" and which to suppress as unimportant or unreal. It is the ability to disattend, to selectively ignore aspects of our experience, which makes the production of a meaningful story line possible. ${ }^{17}$ If these marginalized experiences are brought into focus, they can induce a re-alignment of the framework, or possibly a breakdown and transformation of the frame. This is the process through which ideational change occurs.

15 McLeod, 32-33.

16 Erving Goffman, Frame Analysis: An Essay on the Organization of Experience (Cambridge, MA: Harvard University Press, 1974), 21.

17 Ibid., 202. 
Frame alignment - bridging, amplification, extension and transformation

Goffman documents numerous examples of frame adjustments and frame breaks induced through political action, theatre, advertising and humour. In 1986, David A. Snow headed a research project that used frame analysis to analyze social movements, focusing on the techniques used by leaders to attract supporters to their campaigns. ${ }^{18}$ Snow and his colleagues employed Goffman's theory to analyze frame alignment, which they divided into four major categories:

(1) frame bridging, in which the goal of a leader or movement is linked to an existing value or belief;

(2) frame amplification, in which beliefs or values are highlighted and clarified;

(3) frame extension, which differs from frame bridging in that it draws on goals or beliefs marginal to the leader or movement to make links to the values of the audience or constituency;

(4) frame transformation, in which values and beliefs are presented in an unfamiliar context .

These four strategies can complement each other, and often a single text may employ several different approaches. Snow et al. break down these four categories into smaller sections, differentiating for example between the amplification of values and beliefs. They also allude to a key differentiation made by Goffman, which is the distinction people draw between activities that are perceived to be natural, or purely

18 David A. Snow et al., "Frame alignment processes, micro-mobilization, and movement participation." American Sociological Review 51 (1986). 
physical, and those that are perceived to be social, or guided by intelligence (although not necessarily consciously. $)^{19}$ Snow et al. use this distinction in a modified way, in that they suggest that one of the primary tasks of many political campaigns is to re-frame an activity as socially-constructed in order to make change appear possible. This clarifies the relationship between the examination of frame alignment strategies and postcolonial analysis, since the denaturalizing of the colonial discourse is a necessary first step in the presentation of alternative worldviews. Frame analysis is itself a denaturalizing activity. Because frame theory focuses on understanding the process of creating change, it tends to foreground resistance and support a postcolonial approach to reading history.

\section{Historical sources}

In addition to the theoretical studies discussed above, I have consulted a wide variety of historical sources in the course of this research. The following literature review is organized into three sections: Aboriginal history, studies of Aboriginal politics and resistance and the history of government land use, especially parks. Some sources overlap categories, while others do not fit easily into any of them. The reviews presented here clearly omit many possible sources of information on these three substantial subjects, and represent only the sources I found most useful to this particular study.

\section{$\underline{\text { Aboriginal history }}$}

According to many historical accounts, the Ojibway migrated west from the Great Lakes in the eighteenth century as a consequence of the many conflicts induced by the fur

19 Goffman, 22. 
trade. The Ojibway were a powerful nation in this period and greatly expanded their territory. The Treaty \#3 area, including the Quetico, was part of this new territory. In his 1885 History of the Ojibwa $a^{20}$ William Warren, himself an Ojibway from Minnesota with connections to a prominent Canadian Métis family from Sault Ste Marie, the Cadots, described the migrations and battles of the Ojibway in detail, including a major expansion of Ojibway territory into north-western Ontario in the seventeenth and eighteenth centuries.

For general introductions to Canadian Aboriginal history I have relied on two main sources, Canada's First Nations, by historian Olive Dickason, and First Nations in Canada, edited by sociologist Rick Ponting. ${ }^{21}$ The most recent and specific resources focusing on the Ojibway of Treaty \#3 are the numerous studies by Leo Waisberg, Tim Holzkamm, and Joan Lovisek, many of which are reports on Treaty and Aboriginal Rights Research (TARR) prepared for the Treaty \#3 Grand Council in the last decade. While these studies have a mandate to support political processes such as self-governance negotiations, they offer information from a wide variety of sources, including national and provincial archives, the Hudson's Bay Company Archives and oral history gathered through interviews. They are both valuable historical sources and important indicators of contemporary Ojibway strategic approaches to government negotiation and public relations.

\footnotetext{
${ }^{20}$ Warren, William W. History of the Ojibway Nation. Saint Paul, MN: Minnesota Historical Society 1885; reprint, Minneapolis: Ross \& Haines Inc, 1957.

${ }^{21}$ Olive Patricia Dickason, Canada's First Nations: A History of Canada's Founding Peoples from Earliest Times. $3^{\text {rd }}$ ed. (Toronto: Oxford University Press, 2002); and J. Rick Ponting, First Nations in Canada: Perspectives on Opportunity, Empowerment, and Self-Determination (Toronto: McGraw-Hill Ryerson, 1997).
} 
Aboriginal Resource Use in Canada ${ }^{22}$ is a recent collection of essays that includes a number of chapters focused on the Ojibway. Most significant for this paper is David McNab's contribution on the history of the creation of Quetico Provincial Park and the loss of the Sturgeon Lake reserve. He examines the 1913 federal-provincial negotiations over the Treaty \#3 reserves, which the Ojibway were not invited to attend. Through this example, $\mathrm{McNab}$ explores the major role that federal-provincial politics have played in the Ojibway's loss of control over their territory.

Studies of Aboriginal politics and resistance

Recent ethnohistorical studies of the Ojibway, although not focused on the Quetico area, nevertheless offer some important analysis of nineteenth and twentiethcentury Ojibway political structures and practices. Of these, Janet Chute's 1998 study of the nineteenth-century Ojibway political leader Shingwaukonse is particularly relevant to this study, since it focuses specifically on an analysis of changing political strategies. Shingwaukonse was a chief at Garden River, near Sault Ste. Marie, from the 1820 's until his death in 1854. Chute argues that self-interest is and has long been contained through a system of checks and balances in Ojibway societies. The political changes she explores in her study are not changes in the structure of Ojibway leadership, but rather the developments of new strategies for survival. She concludes that, in the nineteenth century, Ojibway leaders at Garden River moved from a strategy of petitioning for assistance from the colonial government to an emphasis on the survival of Ojibway political and cultural institutions, including the preservation of a land base.

${ }_{22}$ Kerry Abel and Jean Friesen, eds., Aboriginal Resource Use in Canada: Historical and Legal Aspects (Winnipeg: University of Manitoba Press, 1991). 
Chute draws heavily on the work of fellow anthropologist Mary Black-Rogers. BlackRogers researched the concept of "starving" as recorded by Hudson's Bay Company fur traders, and suggested a set of related narrative strategies were being used by the Ojibway to negotiate fur prices. Her 1986 article, "Varieties of 'Starving': Semantics and Survival in the Subarctic Fur Trade, $1750-1850^{\text {"23 }}$ outlined Ojibway traditional practices of avoiding competition, including giving the impression of weakness to avoid appearing to challenge the opponent.

Noel Dyck offers a useful model for the analysis of contemporary Aboriginalgovernment relations in his 1991 book, What is the Indian 'Problem': Tutelage and Resistance in Canadian Indian Administration. He describes "the articulation of tutelage, resistance and co-operation," emphasizing the influence of government strategies on the growth of Aboriginal organizations. ${ }^{24}$ Dyck discusses the development and forms of coercive tutelage in federal policy and explores the relationship between federal and Aboriginal political strategies. He defines tutelage, as applied to Canadian Indian policy, as a concept that proceeds from a premise of settler superiority and establishes the triple goal of restraint, protection and "disciplined instruction." ${ }^{25}$ He differentiates it from the normal student-teacher relationship by emphasizing that it is neither a temporary life stage nor is it based upon a mutual agreement, explicit or implicit. He uses the term "coercive tutelage" to express this distinct form, and sums up the goal of federal Indian administration as being "to save Indians from themselves." 26

\footnotetext{
23 Mary Black-Rogers in Ethnohistory, Vol 33:4 (1986).

24 Noel Dyck, What is the Indian "Problem": Tutelage and Resistance in Canadian Indian Administration (St. John's: Institute of Social and Economic Research, Memorial University, 1991), 28.

5 Ibid., 24.

26 Ibid., 25.
} 
This book also offers useful studies of particular forms of resistance and illustrates some means of identifying covert or passive resistance on the part of Aboriginal leaders and communities. For example, Dyck argues that even when Aboriginal communities have been compelled to adopt a secret ballot election process to elect band councils, they have often exercised covert resistance by electing representatives unlikely to challenge other community leaders. He also suggests that appeals to what he calls 'cultural conservatism' are emerging as a common strategy of Aboriginal leaders. This includes campaigns to preserve Aboriginal languages, in addition to the struggle for land and self-government, in keeping with Ngugi's project of decolonizing the mind, with its emphasis on the relationship between language and resistance. Dyck emphasizes in particular the use of "the politics of embarassment"27 as an effective strategy, using the media to draw attention to human rights violations and other injustices.

Dyck is also the editor of Indigenous Peoples and the Nation-State, an earlier book containing essays on a variety of issues in contemporary Aboriginal politics. Among these, Sally Weaver's chapter on political representivity stands out for its analysis of the problems facing Aboriginal leadership. Weaver emphasizes the vulnerability of a political authority derived from government recognition, which can be withdrawn whenever the individual or group effectively opposes government decisions. She also discusses the tension between the various roles Aboriginal political representatives must play: representing the views of their people to the government and the settler public; creating a "social microcosm" that accurately represents the community in terms of age,

27 Ibid., 117. 
gender and experience; and responding to community needs through the provision of services. ${ }^{28}$ Perhaps because this study's historical dimension is limited to the latter part of the twentieth-century, it does little to address the fundamental dissonance between Aboriginal models of governance and European-derived models of political representation. The problem of representivity, however, is an important one for this study.

\section{History of government policy}

I have also consulted several sources on the evolution of government policy and the changes in settler concepts of land values. Some of these are concerned with federal policy and some with Ontario, and I have emphasized sources related to parklands. Most span a century or more and therefore offer valuable analysis of changes in policy through time.

Historian H.V. Nelles has produced an authoritative history of the development of resource extraction industries in Ontario, including a large section on the lumber trade and some discussion of the major companies operating in the Quetico area. ${ }^{29}$ He explores the economics of forestry and mining in Ontario, and the resulting ties between industry and government, beginning in the nineteenth century. His analysis of the importance of timber dues to provincial revenues, and the evidence of corruption associated with the licensing system, is particularly useful and well-supported.

28 Sally Weaver, "Political representivity and indigenous minorities in Canada andAustralia." In Indigenous Peoples and the Nation-State, ed. Noel Dyck (St. John's: Memorial University of Newfoundland, 1986), 115.

29 H.V. Nelles, The Politics of Development: Forests, Mines and Hydro-Electric Power in Ontario, $1849-$ 1941 (Toronto: MacMillan of Canada Ltd, 1974). 
Gerald Killan has written an official history of the Ontario parks system, which provides context for the many decisions made with regard to the Quetico from 1913 to the present. ${ }^{30}$ While the Aboriginal presence in Ontario parks is not his primary focus, he does discuss some of the many impacts of park development on Aboriginal communities, especially with regard to Algonquin Park, Temagami and the Quetico. His book introduces all the major figures in the Ontario Parks Department from its beginnings and provides background and an analysis of policy decisions.

In addition, numerous historians and legal scholars have documented and commented on the 1888 St. Catherine's Milling case, which resulted in a restrictive definition of aboriginal rights and the involvement of the Ontario government in subsequent land negotiations with Aboriginal people. One of the most useful commentaries is "Challenging Assumptions: The Impact of Precedent in Aboriginal Rights Litigation" ${ }^{131}$ by Catherine Bell and Michael Asch. Bell and Asch explore the impact of the St. Catherine's Milling decision, not only for Treaty \#3 but throughout Canada, due to its interpretation of Aboriginal rights. This article was published as part of a collection entitled Aboriginal and Treaty Rights in Canada, which includes several other essays valuable to this study, such as J. Edward Chamberlin's contribution entitled "Culture and Anarchy in Indian Country." In this chapter, Chamberlin explores the ideals and fears that underlay the development of Canadian Indian policy, in particular in the nineteenth century. S. Barry Cottam has also written a very useful article on the implications of the St. Catherine's Milling decision for the triangle of Aboriginal-

${ }^{30}$ Gerald Killan, Protected Places: a History of Ontario's Provincial Parks System (Dundurn Press: Toronto, 1993).

${ }^{31}$ In Aboriginal and Treaty Rights in Canada: Essays on Law, Equality and Respect for Difference, ed. Michael Asch (Vancouver: University of British Columbia Press, 1997). 
provincial-federal relations, entitled, "The Twentieth-Century Legacy of the St.

Catharine's Case: Thoughts on Aboriginal Title in the Common Law." ${ }^{32}$

A Narrow Vision ${ }^{33}$, Brian Titley's history of the influential Indian Affairs civil servant Duncan Campbell Scott, explains much of the early history of Indian policy in Canada, detailing the changing roles of Indian agents, the early development of Aboriginal political organizations, and outlining the context in which federal policy decisions of the late nineteenth and early twentieth centuries took place. While his predictable emphasis on the role of the federal government overshadows the very powerful political influence of Ontario, I have balanced this against the work of Nelles, Killan and Cottam, discussed above. Given the important role Scott played personally in decisions affecting the Ojibway of the Quetico region, Titley's study provides important historical context.

\section{Some notes on terminology}

Throughout this study, I use the term 'Aboriginal' to refer collectively to First Nations, Métis and Inuit in Canada, and I use the term 'settler' to refer to the Canadian culture that has emerged from colonial settlement of the country, as distinct from a strictly 'white' society. Although I have distinguished between what might be considered classical colonialism and internal colonialism, for the sake of brevity and to emphasize the continuity of the colonial government I generally use the terms 'colonial' and 'the

${ }_{32}$ Barry S. Cottam, "The Twentieth-Century Legacy of the St. Catherine's Case: Thoughts on Aboriginal Title in the Common Law." In Co-Existence? Studies in Ontario First Nations Relations, ed. Bruce W. Hodgins, Shawn Heard and John S. Milloy (Peterborough: Frost Centre for Canadian Heritage and Development Studies, 1992).

33 Brian Titley A Narrow Vision: Duncan Campbell Scott and the Administration of Indian Affairs in Canada (Vancouver: University of British Columbia Press, 1986). 
colonial discourse.' Whenever possible, I refer to specific First Nations, to the Treaty \#3 Grand Council, or to the Ojibway. When I refer to 'the Ojibway of the Quetico region,' I am including not only the people of Lac La Croix and Sturgeon Lake, but also the people of Rainy River, Seine River and Lac de Mille Lacs who have used some part of the Quetico. I use the term 'indigenous' when discussing colonialism in general around the world, as distinct from the specifically Canadian experience. 


\section{CHAPTER TWO}

\section{CONTESTED LAND: THE POLITICAL HISTORY OF THE QUETICO}

In this chapter, I examine the development of Ojibway strategies to protect their economy and culture from French, British and American exploitation. Early contact with Europeans was primarily fur-trade related. Beginning in the mid-nineteenth century, however, colonial expansion became a serious threat to the Ojibway way of life. Negotiations over the regulation and uses of the Quetico region have taken place sporadically from that time until the present. The recent history of the Quetico region is dominated by these negotiations and their consequences. Contemporary issues in the Quetico, including park management and restrictions on Ojibway self-governance and land use, can only be fully understood in the context of this history.

Negotiations always require the judicious presentation and framing of arguments. When the two parties come from different cultures, the lack of common history and values only makes this task more difficult. In early negotiations between the Ojibway and colonial government representatives, this was further exacerbated by the lack of a common language and the use of government employees as translators. ${ }^{1}$ The history presented in this chapter will lay the groundwork for an analysis of the framing strategies used by the Ojibway and government representatives, both of which have evolved through time. With this purpose in mind, the history in this chapter emphasizes periods

\footnotetext{
'Dickason, 257.
} 
of direct interchange between Ojibway leaders and government. It therefore only skims over many other aspects of the history of the Quetico, such as the development of the logging industry, the impacts of reserves and residential schools, and inter-governmental discussions over the future of the Quetico.

\section{"A rich country": The treaty-making era}

As early as 1857 , the Ojibway began to refer to their land rights to assert their authority over the territory. At this time, canoe routes through the Quetico were part of the primary route being developed to link Ontario to the West. In 1868, Ontario decided to build a road from the Lake of the Woods to Fort Garry, despite the fact that it had no jurisdiction over this area. The road would eventually stretch from Fort William (Thunder Bay) to Winnipeg, and became known as the Dawson Road, named for Simon Dawson, the engineer who oversaw its construction. The Dawson Road became increasingly important as the Dominion government sought to expand its influence westward and to attract settlers to the prairies. It combined sections of corduroy road with water routes, and was quickly succeeded by the railway, which opened in 1882 . The section that crossed the Quetico was part of the water route, passing through both Sturgeon Lake and Lac La Croix.

In 1857, at Garden Island, located west of the Quetico on Rainy Lake, a group of fifty-three Ojibway men confronted the Red River Expedition Party. This was a group of scientists and engineers, including Simon Dawson, sent by the government of Canada West to sketch a route to the prairies and propose possible locations for settlement along 
the way. ${ }^{2}$ The Ojibway sternly warned the expedition not to stray from the existing road. They insisted that the Canadians sit down to discuss the matter with them. The chief described the territory as a home, saying "Remember, if the white man comes to the Indian's house, he must walk through the door, and not steal in by the window." ${ }^{3}$

In this period, there were still concerns about possible American expansion north of the forty-ninth parallel into Rupert's Land, the vast territory under the control of the Hudson's Bay Company. In addition, the Red River Métis were increasingly asserting their independence from the trading limits imposed by the Hudson's Bay Company, a foretaste of the rebellion to come. For all these reasons, the Dawson Road held great strategic importance to the Dominion.

In an 1870 memorandum, Simon Dawson referred to the Ojibway of this area as "that powerful Indian Community." ${ }^{4} \mathrm{He}$ also estimated that 3000-3500 Ojibway lived solely on the British side of the border, not including those people who fished or trapped partly in the United States, whom he considered ineligible for treaty negotiations. ${ }^{5} \mathrm{He}$ cautioned the government that "those Indians hold a very critical position on the line of route [for the proposed road] and that, if disposed to hostility, they might give a vast amount of trouble." ${ }^{6}$ Furthermore, he quoted "an officer of high rank and great experience" as saying that a hostile reception by the Ojibway would have made the

\footnotetext{
${ }^{2}$ The Ojibway of the Treaty \#3 area traditionally hunted and fished, but they also harvested wild rice and cultivated gardens of corn, squash and potatoes, hence the name "Garden Island." Hind had picked some of the corn growing on the island as a sample for his collection, which the Ojibway objected to strenuously. The Ojibway gardens are frequently mentioned in early government reports, and appear to have been an important food source. Despite this, the Ojibway were not considered to truly practice agriculture, one of the signs of civilization, because they were nomadic.

${ }^{3}$ Unnamed chief in Henry Youle Hind, Narrative of the Red River Exploring Expedition of 1857 and of the Assinniboine and Saskatchewan Exploring Expedition of 1858, 2 Vols (London: Longman, Green, Longman and Roberts, 1860; reprint New York: Greenwood Press, 1969), Vol I: 99.

${ }^{4}$ Simon Dawson to Hector Langevin Dec 19, 1870, ADS, NAC CO 42/698

${ }^{5}$ Ibid., pp.126 - 129

${ }^{6}$ Ibid., p.144
} 
Dawson Road "impracticable" despite the fact that the Expedition Party took with it "a thousand armed men." 7 The relationship between the Dominion and the Ojibway at the beginning of treaty negotiations was therefore more balanced than later histories have sometimes professed.

The Ojibway of the Quetico and Rainy River region were also well-connected to other Ojibway groups, and thus received information about Aboriginal-settler relations in other places. In his report on the 1857 meeting with the Ojibway, Dawson noted their opposition to land cession treaties such as those underway in the United States, as well their fear of being cheated by government. ${ }^{8}$ In her study of Shingwaukonse, Janet Chute records several meetings with "western Ojibwa allies" to discuss the Garden River chief's plan to create an Ojibwa homeland in the Sault Ste Marie area, beginning as early as $1846 .^{9}$ She suggests that the delegates, including representatives from Rainy Lake and Lake of the Woods, "proved impatient by the spring of 1846 for the Canadian government to grant leave for their move to the projected Ojibwa settlement."10 By 1859 , therefore, they would certainly have been aware of the Robinson treaties and the impacts of industrial activity around Lake Superior. ${ }^{11}$

In 1869, the Hudson's Bay Company (HBC) lands, including the Quetico, were transferred to the newly-created Dominion of Canada. The Quetico was included in the portion called Keewatin. This land transfer also provided a focus for Métis aspirations of a separate nation; they had been in conflict with the HBC since the early nineteenth

\footnotetext{
${ }^{7}$ Ibid.

8 "By Telegraph - British North America" Globe and Mail (Toronto), Aug 8, 1859, p.2

${ }^{9}$ Chute, 109,118 and 122.

${ }^{10}$ Ibid., p.109

${ }^{11}$ The two Robinson treaties, the Robinson-Huron Treaty and the Robinson-Superior Treaty, were negotiated in 1850 and covered the area north of the Great Lakes as far as the height of land. They set the patterns for subsequent treaty negotiations, such as the allocation of reserves and the retention of hunting and fishing rights. Mining activities north of Lake Superior had already begun at this time.
} 
century, but the findings of the Red River Expedition Party had been used to argue against the creation of a separate Red River colony, leaving the area under HBC control. The construction of the Dawson Road in 1868 made control over the area by the new Canadian government feasible, and John A. Macdonald had committed to taking over the HBC lands as part of the Confederation negotiations. Louis Riel led the Métis in the establishment of a provisional government in Manitoba on December 27, 1869, less than four weeks after the official transfer of control from the HBC to the Dominion. When the provisional government court-martialled and executed the Orangeman Thomas Scott on March 4, 1870, for refusing to keep the peace, French-English conflicts were inflamed, threatening chaos. Prime Minister Macdonald quickly organized the creation of Manitoba as a new province, established May 12, 1870.

The 1870 Red River crisis created great anxiety in Ottawa, as Quebec rose to the defense of the Métis, and the Americans watched the proceedings carefully, still hoping for an opportunity to annex the territory themselves. Furthermore, the legality of the act establishing the new province was questionable, because Aboriginal land rights had not yet been extinguished. Treaties \#1 and \#2 were negotiated in Manitoba in 1871, and involved western Ojibway and Swampy Cree together with smaller bands. These treaties were characterized by their stingy terms, and were subsequently re-negotiated in 1875 . Olive Dickason has noted that the poor terms of these treaties did not reflect a lack of negotiating skills on the part of the chiefs, but rather the government's 'take-it-or-leave-it' approach, which meant that in the final analysis the Indians had little choice. ${ }^{12}$

\footnotetext{
${ }^{12}$ Dickason, 257.
} 
The Dominion also made its first attempt to negotiate Treaty \#3, also known as the Northwest Angle Treaty, in July 1871. The Indian Commissioner was Wemyss Simpson, who had negotiated Treaties \#1 and 2. Simon Dawson was also appointed to the Commission to negotiate Treaty \#3. The commissioners sought primarily to secure passage for immigrants moving west along the new Dawson Road, and secondarily to allow for the possibility of settlement in the Northwest Angle area itself. The Dominion recognized that the poor soil made most of the area unfit for agriculture, and already was beginning to dissuade settlement in northern Ontario. ${ }^{13}$ The Ojibway were willing to negotiate passage through their territory, but rejected the concept of surrendering their land and moving onto reserves. ${ }^{14}$

Negotiations thus failed in 1871 and again in 1872 . The second attempt ended with Indian Commissioner Simpson reporting in a terse telegram to Secretary of State Joseph Howe that "Rainy Lake Indians refuse to come into treaty arrangement at present." ${ }^{15}$ In a letter dated July 17 th, Simpson complained that the commissioners had "done everything in [their] power to negotiate a treaty" but that "the Indians could not be induced to go into the discussion of the provisions made in the various articles of the treaty." 16 In short, the Ojibway refused to negotiate without beginning with a broader discussion, one that included questions of redress for past uses of their land, mineral rights, and comparisons with treaties recently signed by Ojibway in the United States.

\footnotetext{
${ }^{13}$ With the exception of a known belt of fertile land in the Fort Frances area.

${ }^{14}$ The concept of Indian reserves had been introduced in the 1763 Royal Proclamation, defined as land reserved by the British (later the Canadian) government for exclusive use by Aboriginal people. ${ }^{15}$ Simpson to Joseph Howe July 24, 1872, TD, NAC RG 10 Vol 1868 file 577. The position of Secretary of State included the title of Superintendent-general of Indian Affairs until 1873.

${ }^{16}$ Simpson, Dawson and Pither to Joseph Howe, July 17, 1872, ALS, NAC RG 10 Vol 1868 File 577
} 
After fourteen days, during which the council met daily, the commissioners gave up and left. Newspaper reports of the meetings between the two groups record that Chief Blackstone of Lac La Croix emerged as a significant political leader, although, in keeping with the prejudices of the day the reporter believed that he gained this role by:

imposing upon the whites, by lying to his brethren, by indirectly intimating to the one that he might cause trouble on the road, and to the other that he was in the confidence of the greater chiefs among the white people, and above all by irrepressible impudence. ${ }^{17}$

In addition, Chief Blackstone apparently attempted to organize a deputation of chiefs to travel to Ottawa to meet directly with the Superintendent-General, presumably out of dissatisfaction with the commissioners. Robert Pither, a government employee and former Hudson's Bay trader who would subsequently become the first Indian agent for Treaty \#3, "interfered by telling the other chiefs such a meeting was impossible." ${ }^{18}$ Blackstone persevered, however, and traveled to Thunder Bay, but was thwarted when Governor Simpson told the captains of all the steamers to refuse him passage "on account of the Indian Department."19 Although it is unlikely that Simpson had in fact secured such an order from the Department, his claim was successful, and Chief Blackstone was unable to obtain passage across Lake Superior.

Chief Blackstone was far from alone in his distrust of the commissioners, however. The same reporter also noted that at one meeting, at which the young men were demonstrating their disrespect through behaviour the reporter described as "impudent, noisy, and generally objectionable," one man "followed the Commissioner along the stage, mocking him," while another "stalked into the dining room of the Fort to help

\footnotetext{
${ }^{17}$ Clippings sent to William Spragge by Burton Marshall in a package dated Aug 29, 1872.

${ }^{18}$ Same clipping as above.

${ }^{19}$ Same clipping as above.
} 
himself to a glass of ice-water."20 These actions were dismissed by the reporter as youthful disrespect, but they may have represented a much more serious criticism of the commission than he realized. At the very least, they demonstrate the confidence of the Ojibway and their dissatisfaction with the commissioners and the treaty process. The reporter also indicated that they had good relations with the Ojibway at Vermilion and Leech Lake, two American reserves, and were familiar with conditions on the U.S. side. In addition, Chief Blackstone had brought up the issue of mineral rights, threatening to disrupt any mining actions on Aboriginal land. From the reported meetings between Western Ojibway leaders and Shingwaukonse, he may have been familiar with the resistance of the Ojibway at Garden River, who had forcibly shut down a mine on their territory. Certainly, the commissioners would have been aware of this and other similar incidents. The 1872 negotiations thus ended in chaos.

In 1873 Lieutenant-Governor Alexander Morris replaced Wemyss Simpson as Indian Commissioner. The new negotiating team also included two Indian agents, Robert Pither and J.A.N. Provencher, a translator named McPherson, a government interpreter, and an assistant. ${ }^{21}$ The Ojibway sent twenty-four representatives, of whom three acted as primary spokesmen. Chief Blackstone represented the eastern region, including Lac La Croix, his home village; Mawedopenais from Long Sault spoke for the Rainy River district; and Powassin from Northwest Angle represented the Lake of the Woods. They also brought with them a recorder, probably a traditional mishinaway, whose duty was to commit the events to memory, and a French note-taker, Joseph Nolin. The meetings opened on October 2, 1873 at the Northwest Angle on the Lake of the Woods.

\footnotetext{
${ }^{20}$ Another clipping from the same collection, also n.d.

${ }^{21}$ Of these men, McPherson was subsequently fired for drunkenness and Provencher for corruption, while Pither seems to have been strongly disliked and mistrusted by the Ojibway.
} 
Chief Mawedopenais opened with a complaint that the Ojibway had previously been "robbed" by Europeans, and were determined to get a fair deal this time. ${ }^{22}$ The chiefs argued that the travel over the Dawson Road and the presence of prospectors were indications that their territory was "a rich country." ${ }^{12}$ They brought up concerns about mineral rights, asked questions about how the terms of the treaty would be honoured, and demanded the inclusion of Métis in the treaty payments. They requested assurances that they would continue to have access to their hunting and fishing territories and asked for more supplies, larger cash payments and free passes on the forthcoming railways.

From the commissioners' point of view, the Ojibway were hard bargainers. Since the government needed a treaty, however, negotiators persisted, eventually granting somewhat more generous terms than Treaties \#1 and 2. These included not only more money, supplies and reserve land, but also rights for the $\mathrm{Métis}^{24}$ and hunting and fishing rights throughout much of the territory. Twice the chiefs refused to sign the treaty; the final negotiations took fourteen days.

The resulting treaty allowed for reserve lands to be established in locations selected by the Ojibway. While the government intended these to be primarily agricultural settlements, the treaty also acknowledged the ongoing reality of hunting and fishing and allowed reserves to be selected for these purposes. Whatever the intentions of the commissioners, it would soon become apparent that the government was unwilling to honour these promises. Furthermore, although the Ojibway specifically requested that a Métis named Charles Nolin be named as their Indian Agent, the Crown instead selected

\footnotetext{
${ }^{22}$ Quoted in Alexander Morris The Treaties of Canada with the Indians (Toronto: Belfords, Clarke, 1880; reprint, Toronto: Prospero, Canadian Collection, 2000), 62.

${ }^{23}$ Ibid.

${ }^{24}$ Although the concept of Métis rights was later revoked by federal legislation, the Rainy River Métis retained their status by electing to be considered as Indians under the law.
} 
Robert Pither, the same man who had interfered with Chief Blackstone's planned trip to Ottawa in 1872 . For the Ojibway, he would prove to be an unhappy choice.

\section{Colonialism bears down: 1873-1909}

While the initial treaty required Aboriginal consent to any sale or lease of reserve lands, this right was rapidly eliminated not just for the Indians of Treaty \#3 but across the country. First in 1879, then again in 1884 and 1894, the power to allot reserve lands and to lease "undeveloped" reserve lands was removed because the bands were resisting such initiatives. In 1898, ongoing opposition to land development on the part of the band councils led to this right being permanently removed and placed in the hands of the Superintendent General, a position held by the Minister of the Interior. Between 1896 and 1909 the department sold 293, 606 hectares of reserve lands, at a profit of $\$ 2,156,353$ for the federal government. ${ }^{25}$

While this loss of rights certainly had an impact on the Ojibway, an even greater problem was posed by the fact that Ontario had opposed Treaty \#3 ever since the territory was initially placed under the jurisdiction of Manitoba. In 1878, a Board of Arbitration ruled that this territory should be considered part of Ontario, but Prime Minister Macdonald refused to accept the ruling. In the 1882 election campaign he argued that the lands in question, conveyed through treaties, now belonged to the Dominion. As a result, the Northwest Angle had "not one stick of timber, one acre of land, or one lump of lead, iron or gold that [did] not belong to the Dominion." 26 Staunch in his opposition to the Ontario Liberal government led by Oliver Mowat, he began to

\footnotetext{
${ }^{25}$ Dickason, 303.

${ }^{26}$ Quoted in Cottam, 120.
} 
give away timber limits in the Northwest Angle area to demonstrate his control over the land.$^{27}$

Premier Mowat and his government were not about to accept this denial of what they considered their land rights, and in 1881 they took the federal government to court in the St. Catherine's Milling case, arguing that the BNA Act granted sole control of Crown Lands to the provinces, and that the federal government had no right to sell timber licenses. ${ }^{28}$ In 1885 , Ontario won, and the court declared Treaty \#3 invalid. The federal government appealed to the Ontario Court of Appeal, the Supreme Court of Canada, and finally, in 1888, to the Privy Council in London. Ontario won at every level. While Indian treaties were not ultimately invalidated, the power of the federal government to enforce them was severely curtailed, since the provinces were given almost exclusive control over Crown lands. In 1894, the federal government took the further step of offering to include Ontario in any future treaty negotiations.

For the Ojibway of Sturgeon Lake, this agreement between Ontario and the federal government, which lay completely outside the original terms of the treaty, was to prove an insurmountable obstacle to the retention of their land rights. This was evident almost immediately. In October of 1894, the Deputy Superintendent-General of Indian Affairs received a request from the Sturgeon Lake Band for an exchange of land. ${ }^{29}$ The band had noted that the presence of stagnant water made their present reserve unhealthy, in addition to which it did not have adequate access to their major food sources. They asked the Indian agent if they might exchange Reserve $24 \mathrm{C}$ for a parcel of land of

\footnotetext{
${ }^{27}$ Ibid., 120 and 125 n. 12 .

${ }^{28}$ The arguments made by Ontario and the Dominion are discussed in more detail in Chapter Four. ${ }^{29}$ Ebeneezer McColl, Inspector of Indian Agencies, Manitoba to Hayter Reed, Deputy SuperintendentGeneral of Indian Affairs Oct 30, 1894, ALS, NAC RG10 Vol 7537, File 27, 124-9
} 
equivalent size, 5762 acres, on some small lakes slightly north-west, at a site known as the Deux-Rivières Portage. The bureaucracy of Indian Affairs required that they make their request to the Indian Agent, who in turn passed on the request to his superior, the Inspector of Indian Agencies, Manitoba Superintendency. He then noted his strong approval of the request and passed it on to the Deputy Superintendent-General, Hayter Reed. Had the request been made in 1893, it might well have been accepted, for Reed noted that "the Department is very anxious to comply with the request of the Indians and would therefore strongly urge that the exchange asked for be granted." 30

Unfortunately for the Ojibway, however, Superintendent-General Thomas Daly did not approve the request, but asked that it first be sent to Aubrey White, Assistant Commissioner of Crown Lands, Ontario, since the land was in "the 'Disputed Territory."'31 On February $4^{\text {th }} 1895$, White responded, saying that he wished to delay the decision until he received a report on the reserves in the area. This was clearly an excuse, however, for he went on to suggest that "perhaps it would be as well to let the matter rest until the whole question has been settled as between the two Governments." ${ }^{32}$ Furthermore, White noted that the land in question was surrounded by timber berths that had already been sold by his department, and that it contained a Hudson's Bay post. There is no further correspondence on this topic between Ontario and the Dominion until 1913. The Inspector of Indian Agencies wrote again in June, passing on a request from his agent that he be able to give a response to the Ojibway during his annual visit to Sturgeon Lake to make the annuities payments. Reed repeated White's excuses about the report, the Hudson's Bay post and the timber berths, and then quoted his suggestion that

\footnotetext{
${ }^{30}$ Hayter Reed to Aubrey White, January 15, 1895, TDS, NAC RG 10 Vol 7537 File 27, 124-9

${ }^{31}$ W.A. Austin to Hayter Reed January 11, 1895, TDS, NAC RG 10 Vol 7537 File 27, 124-9

${ }^{32}$ Ibid.
} 
the request be dropped. The issues of shortage of food and unhealthy water, complaints that had been corroborated by both the agent and the inspector, went unaddressed. ${ }^{33}$

Conditions at Sturgeon Lake seem to have deteriorated particularly sharply through this period, which saw the advent of commercial logging and hydro-electric developments as well as the introduction of the reserve system. In 1894 the agent reported "protracted sickness" resulting in "destitution. ${ }^{134}$ Considering the situation in the Quetico, this was likely an accurate perception, although the use of such language has been deservedly critiqued as reflecting a Eurocentric perception of Aboriginal life. Viewed from the perspective of Europeans, the lack of material goods was commonly referred to as an indicator of poverty. Similarly, the materials used to produce Aboriginal homes, clothing and foods seemed to many European observers to indicate a desperate lack of European-style resources. ${ }^{35}$ In the late nineteenth century, however, rapid economic and ecological changes did leave many Aboriginal people unable to successfully pursue their traditional ways of life. In combination with the continuing impact of European diseases, this resulted in much poverty and suffering among the Ojibway.

The agent also noted that "[t]he American side is now settling and they [the Ojibway of Treaty \#3] are rapidly being hemmed in on their Reserves on all sides" ${ }^{\prime 36}$ and in an earlier letter explained that new dam projects were destroying wild rice crops by

\footnotetext{
${ }^{33}$ Hayter Reed to Ebeneezer McColl, June 12, 1895, TDS, NAC RG 10 Vol 7537 File 27, 124-9

${ }^{34}$ T.C. Comish to Inspector of Indian Agencies, Sept 9, 1894, ALS, NAC RG 10 C-V-23 Outgoing Correspondence

${ }^{35}$ Mary Black-Rogers "Varieties of 'Starving': Semantics and Survival in the Subarctic Fur Trade 17501850." Ethnohistory Vol 33:4 (1986): 352-383 passim.

${ }^{36}$ T.C. Comish to Inspector of Indian Agencies Sept 4, 1894, ALS, NAC RG10-C-VI Outgoing Correspondence
} 
raising the water levels in the lakes. ${ }^{37}$ In addition, fires were "raging all over the country"38 and presumably drove away game, although the agent was concerned more with the loss of timber. While the agent believed that "the young men on these Reserves have abandoned the Hunt," ${ }^{139}$ this is extremely unlikely, especially considering subsequent developments. There may have been less evidence of hunting and trapping, however, since settlement, logging and fire would all have acted to reduce the number of game animals in the area.

Also in 1894 , the agent noted the "exceptionally rough and rowdy element" among the white settlers, due to the shortage of work. While the Sturgeon Lake band had in the past found some work on the railroad and in the mines on the American side, this now became extremely scarce. ${ }^{40}$ Finally, as another result of dam activity, the Ojibway gardens were largely destroyed by flooding in that same year. ${ }^{41}$ The collective result was that game was scarce, the wild rice crop and the gardens were both damaged, and there was virtually no paid employment available for Aboriginal people.

It was under these circumstances that the Sturgeon Lake Band had applied for a transfer of reserve land, a request Aubrey White seems to have refused without any serious consideration.

\footnotetext{
${ }^{37}$ T.C. Comish to Inspector of Indian Agencies July 2, 1894, ALS, NAC RG10-C-VI Outgoing Correspondence

${ }^{38}$ T.C. Comish to Inspector of Indian Agencies Sept 4, 1894, ALS, NAC RG10-C-VI Outgoing Correspondence

${ }^{39}$ T.C. Comish to Inspector of Indian Agencies June 12 1894, ALS, NAC RG10-C-VI Outgoing Correspondence

${ }^{40}$ In comparison, ten years earlier, the agent reported that "all the men" of the Sturgeon Lake reserve were away pursuing these two activities. "Special Report" from John McIntyre to Ebeneezer McColl Oct 6, 1884, ADS, NAC RG10-C-VI Outgoing Correspondence

${ }^{41}$ T.C. Comish to Inspector of Indian Agencies June [no date specified] 1894, ALS, NAC RG10-C-VI Outgoing Correspondence
} 
While the creation of an Indian reserve was considered impossible because of the proximity of timber berths, Aubrey White had no trouble overseeing the sale of timber limits next to existing reserves. Licenses to log land around the Rainy River, Lac La Croix and Sturgeon Lake reserves were being snapped up by logging operators, who were also busy negotiating with the bands for the direct sale of logs taken from the reserve lands.

In the records of the Indian agents responsible for Sturgeon Lake a letter appears, dated April 6, 1885, apparently written on behalf of an Ojibway chief. This could possibly be Chief Blackstone, since these records include letters written directly to him, the only Ojibway to be so addressed, and it certainly echoes his tone in the 1872 and 1873 negotiations. One section of the letter reads:

I beg to inform you that in learning that the Canadians is going to drive Timber through our Reserves this spring we are not going to allow unless we get what was promised I may also state that we are Determined this time you are [illegible] yourself that the last time we was promised something we never got [it] we are not going to be fooled this time. ${ }^{42}$

Log driving may have been disturbing to fish and wildlife, but the letter indicates that this complaint was about the incursion of loggers into Ojibway territory. If indeed this was written on behalf of Chief Blackstone, his defiance appears undimmed by twelve years of life under the treaty. His strategy of threatening to interfere with the logging operations, however, does not appear to have been successful. There is no record of a response to the chief, and no indication that loggers were asked to avoid using the waterways that ran through the reserves.

\footnotetext{
${ }^{42}$ Letter forwarded by J.N Pither, Indian Agent to George McPherson, Indian Agent April 6, 1885, L, NAC

RG10-C-VI Outgoing Correspondence
} 
While in this case the issue was the transport of logs through Ojibway territory, there are many examples of direct timber sales from reserve lands, beginning in this period. The 1897-1900 records include a blank form of a license "to cut timber on Indian lands," ${ }^{43}$ indicating that by this time Indian Affairs was sanctioning the activity. The records of the agents give the impression that bands generally appear to have favoured the sale of some logs from their lands, which would be consistent with the many subsequent attempts the Ojibway have made to acquire small-scale logging permits. Under the circumstances, the income that could be derived from even a small amount of logging was more than welcome. While the Department initially forbade these activities, the records show that they quickly recognized their potential to reduce destitution payments, which was the argument made repeatedly by the agents. Cutting was at first very limited, with records showing small payments to the bands from time to time between 1894 and 1912 .

\section{The changing meaning of "wilderness": 1909-1930}

By the 1890 's, professional foresters had developed the idea of the forest reserve. The concept was that an area of land would be withdrawn from settlement in order to assure a good supply of trees for the logging industry. Professional foresters envisioned strict fire suppression and regulations against cutting immature trees as the primary mechanisms that would ensure that these reserves could provide a steady supply of lumber for the industry. Led by the major timber operators in the province, a political lobby first took shape in the 1880 's, and in 1898 the Ontario Forest Reserves Act was

$\overline{43}$ "License to cut timber on Indian lands", TD, NAC RG10-C-VI Incoming Correspondence 
passed. ${ }^{44}$ The first Reserve to be created was Temagami in 1901, followed by Mississagi in 1903 and Nipigon in 1905. Quetico would be the fourth.

In 1905, the Minnesota legislature set aside a large park area and forest reserve that ran along the Ontario border, including the southern shore of Lac La Croix. Christopher Andrews, the driving force behind this new park, simultaneously began to lobby the Ontario government to expand the Minnesota reserve by creating a park, forest and game reserve in the Quetico area. In the absence of any Canadian conservation movement, the Ontario government initially ignored this proposal. In 1908, however, sport hunters began to complain that game, especially moose, were rapidly declining in the Quetico area. This was a result not only of their own activities, but also of the professional hunters who provided meat for lumber camps. The MLA for Rainy River, William Preston, joined with a representative from the Canadian National Railway to lobby for the creation of a game preserve in the Quetico. Both were motivated by the prospect of tourism, especially the Americans they hoped would be drawn to the new Minnesota park. When these two spokesmen approached Ontario Lands and Forests Minister Frank Cochrane, they told him that U.S. President Theodore Roosevelt was planning to establish a National Forest which would include the Minnesota preserve. According to historian Gerald Killan, this so impressed the Minister that he immediately suggested creating a game preserve in the Quetico. ${ }^{45}$

On March 29, 1909, six weeks after Roosevelt created the Superior National Forest, Aubrey White presented Cochrane with a proposal to create the Quetico Forest

\footnotetext{
${ }^{44}$ Bruce W. Hodgins, R. Peter Gillis and Jamie Benedickson "The Ontario Experiments in Forest Reserves," in Changing Parks: The History, Future and Cultural Context of Parks and Heritage Landscapes, ed. John S. Marsh and Bruce W. Hodgins (Peterborough: Frost Centre for Canadian Heritage and Development Studies, 1998), 83.

${ }^{45}$ Killan, 23.
} 
Reserve. This measure, he assured the Minister, would act as a game reserve as well as a forest reserve, and would require minimal commitment from the province, since the land in question was not particularly valuable. White was clearly a skillful negotiator, and it is reasonable to question his sincerity in this case. Two particular elements stand out. First, although he argued that the land was not valuable, he recently refused to allow the Sturgeon Lake Ojibway to have a reserve on it because of its timber berths, timber licenses being a major source of provincial revenue. Second, as noted by Killan, he neglected to mention that an amendment to the Forest Reserves Act in 1900 actually made fishing and hunting permissible in Forest Reserves, subject only to the creation of regulations. ${ }^{46}$

The proposed forest reserve also threatened to impact the Lac La Croix and Sturgeon Lake reserves, since both were included within its borders. White now glibly assured Cochrane that "the Indians would not be interfered with." ${ }^{47}$ This statement was, at the very least, extremely misleading. White was successful, however, and on April 1st, 1909, an Ontario Order-in Council created the Quetico Forest Reserve.

As a game reserve, Quetico was a total failure. Game and Fisheries

Commissioner Kelly Evans found that there were no rangers at all patrolling the reserve from October to May, and only ten, working in pairs, during the summer months. In a forty-five hundred square kilometre park, traveling on foot and by canoe, five pairs of rangers were unlikely to apprehend many poachers. The people they were most likely to encounter were in fact the Ojibway, who used many of the same sites year after year. Indeed, a letter of complaint written in 1910 indicates that the Sturgeon Lake band was

\footnotetext{
46 Ibid., 24.

${ }^{47}$ Quoted in Killan, 23.
} 
actively prosecuted by the wardens. ${ }^{48}$ Furthermore, the provincial government passed regulations to allow some hunting and fishing in forest reserves in October 1911. Poaching continued to be a major problem, however, with the blame being laid at the feet of the professional hunters serving the logging camps. This continued loss of game eventually led to the re-designation of Quetico as a provincial park in 1913.

Ironically, the forest reserve project was quickly rejected as a failure by Bernard Fernow and other forestry experts. The provincial government proved unwilling to enforce the cutting restrictions, and in 1914 Fernow suggested that at the current rate of cutting, Ontario's forests would be exhausted within twenty-five years. ${ }^{49}$ While his fears were not fully realized, commercial logging was exhausted in many areas, including the Quetico, by the end of World War II.

The inter-governmental struggle over the Northwest Angle lands was finally brought to a close by the 1913 negotiations between Ontario Minister of Lands, Mines and Forests and the Superintendent General of Indian Affairs. Together with their deputy ministers, Aubrey White for the province and the influential Duncan Campbell Scott for the Dominion, they drew up a list of reserve lands in this area of Ontario. This list was incorporated into an Act of Parliament passed in 1914 and into Ontario legislation passed in 1915. Through these Acts, the boundaries and extent of reserve lands were settled - from the government perspective - and Ontario's involvement in later treaty negotiations ensured that such a prolonged conflict over land between the Dominion and the province would not arise again.

\footnotetext{
${ }^{48}$ Quoted in Killan, 25.

${ }^{49}$ Hodgins, Gillis and Benedickson, 87.
} 
For the Ojibway, the result was that Ontario became heavily involved in decisions about which reserve lands they would be allowed, although chiefs and band councils had virtually no access to provincial decision-makers. The provincial MLA for the area, based in Fort Frances, was for many years the prominent timber baron J.A. Mathieu, a man who had little concern for Aboriginal land rights. Furthermore, the nature of the debates ensured that Ontario's attitude towards Aboriginal title would be actively hostile for many years, because it came to view claims to reserve lands as direct competition for timber lands.

Beginning in 1913, the Department of Indian Affairs began a campaign to "clean up the merchantable timber" ${ }^{\prime 50}$ on these reserves. It is not unlikely that this was influenced by the negotiations between Ontario and the Dominion at this time, which aimed to reduce the "excess acreage" of reserves - despite the previous agent's concern that they were being "hemmed in" - by transferring lands to Ontario. Possibly, the agents aimed to cut as much as possible before these transfers took place. In any case, cheque amounts rose noticeably in this period.

The same lack of game that so distressed Commissioner Evans was the cause of major hardships on the Indian reserves. Although there are no Indian agent records available for this period, there is a letter written by Leo Chosa, an Aboriginal trader living on the American side of the border. He explained that the Sturgeon Lake band, unable to find game on their reserve, had set up a camp in the Hunter's Island area of the Quetico reserve. This should have been in keeping with the terms of Treaty \#3, which stated that:

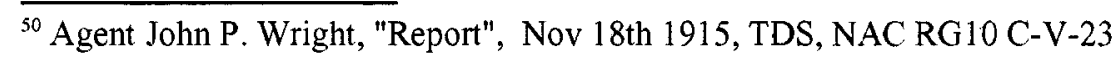


the said Indians shall have the right to pursue their avocations of hunting and fishing throughout the tract surrendered as hereinfor described, subject to such regulations as may from time to time be made by Her Government of her Dominion of Canada, and saving and excepting such tracts as may from time to time be required or taken up for settlement, mining, lumbering or other purposes. ${ }^{51}$

Since this was now a forest reserve, however, such a camp was considered illegal, and provincial officials forced the band to leave Hunter's Island in December 1910, a decision Chosa protested vigorously. "I doubt very much, " he wrote,

that there exists today a civilized people under the sun that would uphold and compel its officers to enforce a law that would deprive a man of his home and throw his wife and little ones on the mercies of a northern winter. $^{52}$

Indian Affairs also complained that "the Ontario Game and Fishery Laws are of late being rigorously enforced as regards the Indians whose rights in the matter are not being acknowledged." ${ }^{53}$ Despite "considerable correspondence" ${ }^{154}$ between Indian Affairs and Ontario, however, the camp was broken up, and the band dispersed to find shelter at Lac La Croix and other reserves. Aubrey White, to whom much of this correspondence was addressed, seems to have done nothing about the fact that the Ojibway were indeed being "interfered with" as a result of the creation of the forest reserve.

The negotiations that created Quetico Provincial Park were only one part of a larger significant process. This was the resolution of the long-standing problem of the Treaty \#3 Indian Reserves. Ontario had long lobbied for reductions in the size of the

\footnotetext{
${ }^{51}$ Northwest Angle Treaty No.3, October 3rd 1873, reproduced in Morris, 320-27.

${ }^{52}$ Quoted in Killan, 25.

${ }^{53}$ Assistant Deputy and Secretary of Indian Affairs J.D. McLean to Indian Agent John P. Wright, December 15, 1910, quoted in McNab, "'Principally Rocks'", 165.

${ }^{54}$ Ibid.
} 
reserves, and these were now obtained. ${ }^{55}$ Aubrey White had complained repeatedly about the extent and location of Indian reserves, and he used the 1913 negotiations with the federal government to eliminate some of them.

On December 9, 1913 the Superintendent General of Indian Affairs, William J. Roche, met in Ottawa with the Ontario Minister of Lands, Forests and Mines, William H. Hearst to discuss the location and extent of Treaty \#3 reserves. Aubrey White, Deputy Minister to Hearst, and Duncan Campbell Scott, Deputy Minister to Roche, were also in attendance. Although it was not unusual at this time to have Aboriginal representatives present at such discussions, no Ojibway attended this meeting. ${ }^{56}$ The agreement reached that day was that the six bands located in the area of the Rainy River were to be amalgamated, and all but one of their reserves "surrendered," along with the Wild Lands reserve. This would involve a nominal negotiation process with the Ojibway, but was essentially an order to accept monetary compensation and leave their lands. Indeed, when one band held a council on the matter and presented a petition questioning their financial compensation, the agent reported to his superior that "I informed him that these Councils held without the Agent being present would have very little effect with the Department. ${ }^{157}$ Needless to say, their request was denied. The agent did, however, pass along their request that the Department's reply be sent directly to the bands, rather than through himself.

\footnotetext{
55 David McNab "The Administration of Treaty 3: The Location of the Boundaries of Treaty 3 Indian Reserves in Ontario, 1873-1915," in As Long as the Sun Shines and the Water Flows A Reader in Canadian Native Studies, ed. Ian A.L. Getty and Antoine S. Lussier (Vancouver: University of British Columbia Press, 1983), 150.

${ }^{56}$ Ibid., 151.

${ }^{57}$ John P. Wright to Duncan C. Scott, January 17th 1916, TLS, NAC RG10-C-V-23
} 
While these bands were essentially forced to sell their reserves, Sturgeon Lake was simply to be "canceled," as Scott expressed it, or "done away with," in White's words. ${ }^{58}$ As a result of the band's recent movements due to the lack of game, they were considered to have abandoned their reserve. The Indian agent, who rarely visited these remote reserves, considered that there were only twelve members of the band remaining, with eight more he considered as migrants, presumably to other reserves. ${ }^{59}$ There may also have been other band members he was not aware of. None of the twenty recognized band members were compensated in any way for the loss of their reserve. Thus the Sturgeon Lake reserve was removed at Ontario's request for the purpose of creating Quetico Provincial Park and opening the land for logging. Six other reserves were subsequently "surrendered" by the Ojibway in March $1915 .{ }^{60}$ The Lac La Croix band effectively lost their rights to the majority of their traditional territory, which as a provincial park now had bans on hunting, trapping and commercial fishing.

Years later, in an official apology to the Sturgeon Lake and Lac La Croix bands in 1991, Ontario Native Affairs Minister Bud Wildman acknowledged some of the impacts of this decision on the Sturgeon Lake and Lac La Croix bands:

These injustices include the removal of families from their traditional lands; the prevention of First Nation members from visiting sacred ceremonial grounds; the disturbance of traplines by provincial officials, and the detention and incarceration of community members for trapping, hunting and fishing. ${ }^{61}$

\footnotetext{
${ }^{58}$ Both quoted in McNab, "'Principally Rocks"', 166.

${ }^{59} \mathrm{McNab}$, "'Principally Rocks'", 165.

${ }^{60}$ John P. Wright to Secretary, Department of Indian Affairs, March 9, 1915, TLS, NAC RG10-C-VI

Outgoing Correspondence

${ }^{61}$ Ontario, Legislative Assembly, Debates, 35th Parliament, 1st session, May 14-June 17, 1991, 1624.
} 
Lac La Croix Chief Steve Jourdain added in an interview at this time that these removals were often at gunpoint. ${ }^{62}$ The information provided by these two sources makes it clear that the Ontario government, which ordered these removals, knew perfectly well that this band was far from extinct. It also indicates that the bands actively resisted this seizure of their territory through continued use and occupation.

The federal Indian agent, for his part, may not have known how many Sturgeon Lake band members there were, nor understood the circumstances in which they were living. In his 1915 report, Agent John P. Wright includes records on the health, activities and numbers of the Ojibway in the Fort Frances agency, including the members of Lac La Croix and Sturgeon Lake. His records reveal, however, that he visited Lac La Croix only twice that year, and Sturgeon Lake, being "canceled," not at all. ${ }^{63}$ These two reserves were much farther away from his Winnipeg office than the Rainy River and Rainy Lake reserves, and required a separate canoe journey of several days. The reports of Indian agents throughout the period demonstrate that the closer reserves were visited far more frequently. When Sturgeon Lake was transferred from the Savanne Agency to the Couchiching agency in 1902 , the Inspector recommending the change noted that the reserve was a seven-day round trip from the next reserve in the agency. He also noted that the reserve itself was not visited at all, for annuity payments were made at another place, called Pine Portage, and this annual visit was the only direct contact between the agent and the band. ${ }^{64}$ It is therefore not surprising that the Indian agents never commented on the scarcity of game in the Quetico, although it was repeatedly reported by the Ontario Game Commissioner from 1908 to 1913, when the park was created. It is

\footnotetext{
62 "Ontario Apologizes to Indians" Globe and Mail (Toronto), June 4, 1991, A2.

${ }^{63}$ Visits to Lac La Croix noted on June 9 and August 9, 1915, RG10-C-VI Outgoing Correspondence

${ }^{64}$ David Laird to Secretary of Indian Affairs, Jan 23rd 1902, TLS, NAC RG10 Vol 1868/577
} 
not clear that they ever understood why the Sturgeon Lake band was moving from place to place throughout this period. As early as 1902 the Indian Commissioner reported that they "never" lived on their land, a comment repeated by subsequent agents. ${ }^{65}$ David $\mathrm{McNab}$ explains that the agents meant that the Ojibway had not constructed permanent dwellings, illustrating a complete ignorance of their way of life. ${ }^{66}$ Despite this, year after year the agents confidently provided population statistics for the Sturgeon Lake band, although they almost never visited the reserve. Furthermore, when they did get to Sturgeon Lake, it was invariably in the height of summer, when nomadic people are generally moving around, rather than winter, when they stay in camp. This helps to explain why the agents' population figures vary significantly from year to year, showing twenty-six members in 1899 , only fourteen in 1905 , and twenty-two in $1912 .{ }^{67}$ It is also quite likely that there were a number of people who never appeared in these lists.

According to the terms of the treaty, the reserve laid out in 1873 was intended for fortyfive people.

Despite the casual assumption by Indian Affairs that the Sturgeon Lake Band simply disappeared after 1913, there is evidence of their continuing use and occupation of their traditional territory. Following the 1910 break-up of the Hunter's Island camp, there were forcible removals of Ojibway from the Quetico in 1913 and $1915 .{ }^{68}$ In 1928, Indian Affairs official J.D. McLean received a report that there remained a small group of Ojibway living at Sturgeon Lake. In answer to the question "Is there anything to show that the Indians were advised as to this [the abolition of the reserve] or any attempt made

\footnotetext{
${ }^{65}$ Ibid.

${ }^{66}$ Quoted in McNab "'Principally Rocks'", 164.

${ }^{67} 1899$ figures are from "Annuities Report for 1898-99", D, NAC RG10-C-VI; 1905 figures are from McNab 1991:164; 1912 figures are from McNab 1991:165

${ }^{68}$ Ontario, Debates, 1624.
} 
to get the Indians a Reserve in lieu?" he wrote casually along the margins "no record." ${ }^{19}$ Despite the fact that the Ontario government had been warned of the necessity of obtaining consent from the band before alienating their territory to create a park, it appears that in fact nothing was ever done, and that Indian Affairs knew it.

There also seems to have been some disagreement between the agents. While Indian agent Frank Edwards reported that "Some of the Indians of the Lac des Mille Lacs Band have lived for years, and still are on this land," ${ }^{70}$ agent Spenser wrote only a few months later, "I have to report that the Indians have not been living on this Reserve for at least Five Years." ${ }^{11}$ It is entirely possible that they were referring to different pieces of land in the Quetico, since the band certainly used Hunter's Island as well as reserve $24 \mathrm{C}$, and probably also the land they had requested in 1894 . It is almost certain that both men were relying on second-hand reports from the band members, since neither one would likely have visited the de-listed reserve. The Lac des Mille Lacs people were almost certainly referring to reserve $24 \mathrm{C}$ in their discussion with Edwards, since it appears that they were in fact making a claim to the land. He states that the chief and councilors asked him about the reserve, and goes on to say that "The Indians claim that this reserve belongs to them."72

In 1931 Indian Affairs reported that there were two surviving members of the Sturgeon Lake Band, and in that same year transferred them to other bands, enabling them to report conclusively that the Sturgeon Lake Ojibway were "extinct."73 From this

\footnotetext{
${ }^{69}$ Internal Memorandum to J.D. McLean Aug 1st 1928, TD, NAC RG10 Vol 7537 File 27, 124-9

${ }^{70}$ Frank Edwards to AF Mackenzie, July 4, 1929, TLS, NAC RG 10 Vol 7537 File 27, 124-9

${ }^{71}$ A. Spenser to Secretary of Indian Affairs, Dec 17, 1929, TLS, NAC RG 10 Vol 7537 File 27, 124-9

${ }^{72}$ Frank Edwards to AF Mackenzie, July 4, 1929, TLS, NAC RG 10 Vol 7537 File 27, 124-9

${ }^{73} \mathrm{McNab}$ "'Principally Rocks'", 168.
} 
point onward, claims to the Quetico would be made primarily by the Lac La Croix First Nation, with access to some resources requested by other bands.

\section{Survival strategies: $1930-1970$}

In the first half of the twentieth century, parks were conceived as havens from city life, recreational playgrounds. Industrial activities within parks were somewhat discouraged since they intruded on the expectation of respite from modern life. In many cases, however, logging and mining were allowed to proceed as long as they were out of the public view. ${ }^{74}$ It is not surprising, therefore, that logging operations continued in the Quetico until 1946. J.A. Mathieu, who had first obtained a license to cut in the Quetico in 1910 , pursued commercial forestry throughout this period. In addition, mining was approved in the park in 1942 as part of the wartime pursuit of minerals, although this never resulted in any substantial operations in the Quetico. Prospecting and mining were subsequently banned in the Quetico and all other provincial parks in 1956, as part of a new philosophy that aimed to create parks that balanced recreation with preservation, as directed by Premier Leslie Frost in his 1959 speech from the throne. ${ }^{75}$

Non-Aboriginal trapping was also taking place in the Quetico, and the Ojibway began to take action to prevent this. Non-Aboriginal trappers operated without respect for traditional family boundaries, which are the expression of Ojibway trapping rights. ${ }^{76}$ In 1946 the Ojibway filed their first application, and in 1948 fifteen traplines were

\footnotetext{
${ }^{74}$ This was true not only in Ontario, but in parks across Canada.

${ }^{75}$ Killan discusses the leadership role Frost played in introducing this new policy direction in Protected Places, 132-33.

${ }^{76}$ Grand Council Treaty \#3, "A brief history of trapping [report on-line]" (accessed July 12, 2002; available from www.treaty3.ca/pages/trapping.html).
} 
granted. This number was later increased to twenty-one. This "privilege"77 required the Lac La Croix First Nation to apply to Indian Affairs, then a branch of the Department of Mines and Resources, who once again requested permission from the province before granting the appeal. The resulting trapline system has proved more or less satisfactory, with amendments made in the 1990's to allow the Treaty \#3 Grand Council more authority over the program. ${ }^{78}$

In 1959, the Lac La Croix band also applied for and received a commercial license for a sturgeon fishery, which they held until 1970. A similar operation to catch whitefish was more short-lived, lasting only from 1960 to 1963 . These activities provided badly-needed revenues for the reserve.

Further to this, in 1964 the Amik Association was formed, a government-funded organization dedicated to the development of on-reserve businesses. Ten bands in the Rainy River area made up the core membership of Amik in the region. Seven nonAboriginal staff people worked for the association, based in Kenora and paid for by a joint federal-provincial grant program. Although the purpose of the program was to provide training, advice and seed capital for new businesses, in practice Amik also became involved in advocacy for Aboriginal rights to use and profit from the land and its resources.

\section{Resurgence: 1971 - present}

In 1971, the issue of commercial operations in the Quetico came to a crisis point. Environmental organizations succeeded in demanding hearings on the future of the park,

\footnotetext{
${ }^{77}$ Killan, 137.

${ }^{78}$ Grand Council Treaty \#3 "A brief history."
} 
and in the meantime, all logging operations were suspended. The hearings on the park took place in April 1971 in four locations: Fort Frances, Atikokan, Thunder Bay and Toronto, and written briefs and letters were submitted not only from Ontario, but also from people in the United States and across Canada. The Ojibway participated in this process, including having a representative on the Advisory Committee and making an official presentation. The resulting report recommended against allowing any further logging operations in the park, but did support the continuation of trapping and the use of motorboats on Lac La Croix. In fact, Lac La Croix was excluded from the park in the boundary revisions, which freed the band somewhat from the restrictive park regulations. ${ }^{79}$ The recommendations of the 1972 report were largely adopted in the subsequent Quetico Provincial Park Master Plan, published in 1977. At this time, several traplines were still held by non-Aboriginal people, as well as some Ojibway from other bands. In the 1982 review of the plan, the Advisory Council requested that these traplines be eliminated by 1985 , but specifically excluded the Lac La Croix from this recommendation. The Minister's response, however, was ominous: "Accepted with the following clarification: This is recognized as an interim step in the ultimate exclusion of all trapping activities from within the park ..." ${ }^{80}$ The conflict over land use continued. Furthermore, the descendants of the Sturgeon Lake band had not forgotten their grievances, and in 1980 launched a specific claim for redress in the matter of reserve 24C. This claim was not settled, and the file is now closed. In 1991 the Lac La Croix First Nation and the Sturgeon Lake Band received an official apology from the Ontario

\footnotetext{
${ }^{79}$ Because the Ontario government adopted a new buffer-zone system at this time, some environmental restrictions extended well beyond the park boundaries.

${ }^{80}$ Ontario, Provincial Parks Council, Quetico Provincial Park Master Plan Review (Toronto: Ministry of Natural Resources, 1982).
} 
Minister of Native Affairs, Bud Wildman. Chief Steve Jourdain accepted the apology, although he also noted the need for action on the part of the federal government. ${ }^{81}$

The 1990's also saw a gradual change in the participation of the Ojibway in the interpretation programs of the park. The Quetico Foundation, which continues to play a major role in the management of the park, notes that after fifty years, they have "established a working relationship with the Lac La Croix First Nation." 82 In February 2001 the Quetico Foundation finally acknowledged requests from the Lac La Croix that photographs of the twenty-eight pictograph sites in the park no longer be reproduced in their publications. ${ }^{83}$ The photographs were removed from their website, although the Foundation continues to distribute materials that were produced before the new policy was implemented.

In 1996, the Grand Council initiated a process for negotiating self-governance, Bimiiwinitisowin Omaa Akiing, which translates as "governance on our land." 84 Negotiations with the federal government and all twenty-eight nations of Treaty \#3 have been underway since that time. Members of Lac La Croix are prominently involved in the Governance Teams, including the Grand Chief of Treaty \#3, Leon Jourdain and the

\footnotetext{
${ }^{81}$ Globe and Mail June 4, 1991 A2 Ontario Apologizes to Indians

${ }^{82}$ Quetico Foundation, The Quetico Foundation Website, accessed April 4, 2002, available from http://www.queticofoundation.org/pictographs.html.

${ }^{83}$ The pictographs are considered by Lac La Croix elders to be sacred sites, and the publication of photographs of them is seen as inappropriate. The change to the Quetico Foundation website can be seen by comparing the website as of February 2, 2001 with the version posted as of February 17, 2001. Internet Archive, The Quetico Foundation Website, February 17, 2001 [archival file on-line], accessed November 20,2002 , available from http://web.archive.org/web/20010418165017/www.queticofoundation.org/pictographs.html, and Internet Archive, The Quetico Foundation Website, February 2, 2001 [archival file on-line], accessed November 20, 2002, available from http://web.archive.org/web/20001213204100/www.queticofoundation.org/pictographs.htm1 ${ }^{84}$ Grand Council Treaty \#3, "Treaty \#3 Bimiiwinitisowin Omaa Akiing: Governance on our Land [report on-line]," accessed July 12, 2002, available from www.treaty3.ca/pages/gov_init.html
} 
Lac La Croix chief, Robert Atatise. The goal of Bimiiwinitisowin is expressed by policy analyst Lori Rice in terms of control over infrastructure:

Jurisdiction in the area of Territorial and Community Infrastructure is inherent. It is comprehensive and holistic and it is part of the social, economic, political, and cultural continuum of the Anishinaabe Nation in Treaty \#3. This means free and unfettered access to the territory. It must flow from the traditional Constitution and reflect the culture and values of the Anishinaabe and it should relate directly to the Treaty, which is the basis of the special relationship between the Crown and the Anishinaabe Nation in Treaty \#3 that includes the fiduciary obligations of the Crown.[emphasis mine] ${ }^{85}$

This process is ongoing, and given recent developments in federal Indian policy, it is likely to take years to resolve. The introduction of the First Nations Governance Act in June 2002 has created friction between the Grand Council and INAC, amplified by the resurgence of conflict in the Grassy Narrows First Nation, a member nation of Treaty \#3. ${ }^{86}$ The Grand Council has played a prominent public role in protesting federal actions on both these issues, and as a result is in a position of direct opposition to federal policy. The federal government in turn has dismissed the concerns of the Grand Council outright. At present, neither side seems open to compromise or negotiation.

This chapter has outlined the chronology of political action in the Quetico since the 1850 's. In the following chapters, these processes and events will be analyzed to examine the development of political strategies through the period. I will explore the forms of the colonial discourse in this history and the nature and extent of Ojibway resistance. Through this analysis, I will demonstrate the importance of a contextualized history in considering contemporary claims to the land.

\footnotetext{
${ }^{85}$ Grand Council Treaty \#3, "Infrastructures[report on-line]," accessed July 12, 2002, available from http://www.treaty3.ca/pages/infrastructures.html.

${ }^{86}$ The Grassy Narrows First Nation, located north of Kenora, is currently maintaining road blockades in the forest around their reserve in an effort to prevent further logging of their traditional lands, which have already been damaged by logging and mining activities.
} 


\section{CHAPTER THREE \\ "WE HAVE SUCH LITTLE VOICE": OJIBWAY POLITICAL STRATEGIES}

In this chapter, I present and discuss a selection of significant texts produced by the Ojibway for the purpose of communicating with the government about land control and regulation in the Quetico. The BNA Act, and subsequently the Constitution, determines in large part the interests of the federal and provincial governments with regard to land. While in general government-owned territory, or Crown lands, are resources and responsibilities of the provinces, an exception is made for federal control of "lands reserved for Indians." In Ontario, as in most provinces, provincial control of Crown lands has been an important source of revenues. For the federal government, reserve lands have sometimes been seen as an impediment to the goal of assimilation. While the land values of the federal government derive primarily from the concept of fiduciary obligation and the policies resulting from this, the Ontario government values land primarily as a resource base. While both federal and provincial policies have changed since the 1870 's, the core values underlying them, derived from the Constitution, remain essentially the same. To successfully negotiate for land and harvesting rights, the Ojibway have therefore needed to align their own values to those of two very different power-holders. 
In order to demonstrate changes in the Ojibway political narrative, I have grouped these texts into four periods. First, beginning in 1857 and continuing until 1930, there are texts pertaining to the negotiation and administration of what would become Treaty \#3, addressed primarily to the federal department of Indian Affairs. From 1930 until 1970, there is an interval of relative quiescence, which I suggest followed from the traumatic losses of land and harvesting rights. The second period of political action, then, begins in 1970 and continues until the 1990 's, and is addressed primarily to the Ontario government. In the 1990 's, the launch of a specific claim with regard to the loss of the Sturgeon Lake reserve and the development of a self-government proposal signaled a return to negotiations with the federal government. I will argue that these four periods demonstrate significant shifts in narrative strategies.

My argument is based on the proposition that a transformation or re-alignment of dominant frameworks of values and beliefs regarding Aboriginal people and land has been and continues to be required to successfully negotiate for Ojibway land rights in the Quetico. This does not diminish the importance of structural opposition to Aboriginal rights; however, I contend that in a situation in which both political opportunities and societal resources are severely limited, the finite, symbolic power of framing strategies becomes a significant tool for change. In order to allow for the possibility of alternatives, the colonial discourse must first be recognized and denaturalized through interrogation: shifting the frame of the issues under discussion is one way to accomplish this. At the most basic level, the simple identification of colonial practices and ideas as problematic begins the process of denaturalization. Only then can alternatives be presented as possible, just and reasonable, allowing meaningful negotiation to begin. 


\section{"We do not want the white man"}

In the Quetico, land negotiations between Ojibway and government were initiated in 1857, when Henry Youle Hind, Simon Dawson and the rest of the Red River Expedition Party were summoned to a meeting with the Ojibway at Garden Island, located on Rainy Lake. At the meeting, the chief attempted to explain his position in terms of European practices and values in a classic example of value amplification. "Remember, if the white man comes to the Indian's house, he must walk through the door, and not steal in by the window."1 He skillfully appealed to the European value of personal, private property to express the Aboriginal concept of appropriate respect for territory. The house and windows metaphor also acted as a bridging device, expressing the need for rules of conduct in terms of an expression of values. The chief refused to send an Ojibway with the Expedition as a guide, rejecting the Expedition's offers of gifts. He explained:

It is hard to deny your request; but we see how the Indians are treated far away. The white man comes, looks at their flowers, their trees, and their rivers; others soon follow; the lands of the Indians pass from their hands, and they have nowhere a home. ... We do not want the white man; when the white man comes, he brings disease and sickness, and our people perish; we do not wish to die. ... [W] wish to love and hold the land our fathers won, and the Great Spirit has given to us. ${ }^{2}$

The chief summarized the known effects of European incursion and colonization, emphasizing the disparity between the seemingly innocuous requests of the expedition and the likely results.

\footnotetext{
${ }^{1}$ Unnamed chief in Henry Youle Hind, Narrative of the Red River Exploring Expedition of 1857 and of the Assinniboine and Saskatchewan Exploring Expedition of 1858, 2 Vols (London: Longman, Green, Longman and Roberts, 1860; reprint New York: Greenwood Press, 1969), Vol I: 99.

${ }^{2}$.Ibid., 99-100.
} 
This meeting conveyed to the Europeans that Aboriginal land values were not to be taken lightly. Rather than ignoring or threatening the Red River Party, the Ojibway insisted that the Europeans sit down and meet with them to discuss the issue of crossing territory. This action both amplified the importance of appropriate behaviour on the part of the Europeans and expressed the gravity of the Ojibway group's concerns. Olive Dickason has suggested that the Ojibway may have been reacting to the Robinson treaties, signed in 1850, treaties involving large land surrenders and the establishment of small, agriculture-oriented reserve communities. ${ }^{3}$

In the 1870 's, the Ojibway expressed their own desire for a treaty multiple times. ${ }^{4}$ While treaty-making is commonly seen as a coercive government initiative, in this case at least the situation was far more complex. The Ojibway, as discussed in chapter one, were a military force to be reckoned with, and they seem to have been aware of their strength. At the same time, they viewed with alarm the increasing European presence in their territory. They wanted a treaty to regulate the behaviour of the Canadians, whereas the Canadians wanted to regulate the behaviour of the Ojibway. Both parties based their treaty goals on a set of land values. The Ojibway spoke of maintaining their freedom of movement, protecting their gardens from development, and regulating such things as the placement of Hudson's Bay Company posts and the sale of alcohol. ${ }^{5}$

Honesty was expressed as a primary value by both sides. As J. Edward Chamberlin states in his article "Culture and Anarchy in Indian Country,"

\footnotetext{
${ }^{3}$ Dickason, 259.

${ }^{4}$ See for example Morris, 55, 56 and 59.

${ }^{5}$ Morris, 70.
} 
failing to keep your word was the quintessentially uncivil, and uncivilized, act. And although they must have had some doubts about the behaviour of the Canadians, they had to assume that they were more or less civilized. ${ }^{6}$

According to Chamberlin, many Aboriginal groups saw treaties as a safeguard against cultural pluralism and therefore as protection for their cultural integrity. The Ojibway of the Rainy River watershed had knowledge of the Royal Proclamation of 1763, which affirmed Aboriginal sovereignty, and they were also aware of the recent changes in the United States. Although the subsequent betrayals of trust on the part of the Canadian government could not have been fully anticipated, the Ojibway did express doubts over the Commissioners' honesty several times. The Canadians in their turn also questioned some of the chiefs' statements, and the chiefs responded indignantly. These doubts and denials were quite likely exaggerated as part of the drama of negotiations, and this served to amplify the importance of a (presumably) shared value of keeping promises.

Treaty negotiation was organized through the Grand Council, taking its lead from the larger community. The Grand Council initially asserted its sovereignty over the land through its refusal to negotiate in 1871 or 1872 . They made it clear to the government commissioners that they were willing only to discuss road access, and not settlement. Although it was ultimately unsuccessful, this was an important attempt to define the frame of negotiations. In frame defining activity, some issues or values are brought to the forefront, while others are suppressed. As discussed in the introduction, this makes frame definition a powerful tool in political narratives, since it determines the questions

${ }^{6} \mathrm{~J}$. Edward Chamberlin, "Culture and Anarchy in Indian Country" in Aboriginal and Treaty Rights in Canada, ed. Michael Asch (Vancouver: University of British Columbia Press, 1997), 36. 
that can be tabled. Through their insistence on discussing road access, the Grand Council temporarily established a position of strength.

The Ojibway were very consistent in their use of this strategy throughout the period of treaty negotiations. Dawson reported that in his meetings with the Ojibway, they took the lead in stating their requirements for peaceful relations. He quotes their representative as telling him in 1870 , "When we meet next summer you must be prepared to tell us where your roads are to pass and what lands you require." ${ }^{7}$ What the commissioners reported as a refusal to negotiate in 1871 and 1872 may have been a stubborn insistence on these pre-conditions. This passage, if correctly interpreted by Dawson in his report, indicates that the Ojibway clearly accepted the concept of trading some land access, but also that they had no intention of giving up their entire territory. The description Dawson reports suggests that they envisioned European land use as limited to specific areas to be negotiated in the treaty.

As described in Chapter One, in the 1872 meetings the Ojibway publicly mocked Governor Simpson on at least one occasion, and the Lac La Croix chief, Blackstone, attempted to over-ride the Governor's authority by traveling to Ottawa, with a delegation of Ojibway leaders, to speak directly to the Superintendent-General. According to the reporter, Blackstone openly questioned Simpson's authority and expressed his faith that a direct representative of the Queen would be more just in treaty negotiations. ${ }^{8}$ Through his words and actions, Chief Blackstone rejected Governor Simpson's conception of the meeting and attempted to transform the frame of the discussion. Such direct challenge to

\footnotetext{
${ }^{7}$ Simon J. Dawson to Hector L. Langevin, Dec. 19, 1870, ADS, NAC CO 42/698 p.136

${ }^{8}$ Clippings sent to William Spragge by Burton Marshall in a package dated Aug 29, 1872 - possibly from the Manitoban, which sent a reporter to the 1873 negotiations.
} 


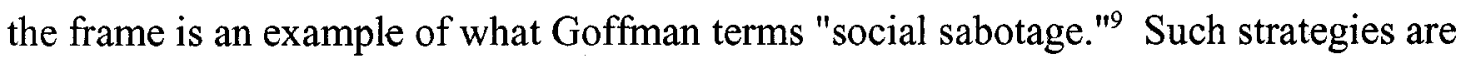
direct attempts to confront, break and take control of the framing process. Although he was unsuccessful in this, Blackstone retained his position as chief until his death, and was selected by the Grand Council as one of three principal speakers at the 1873 negotiations, indicating that his authority within the Ojibway community was in no way compromised by his defiance of the government. His tone echoes the words of the leader described by Simon Dawson as the principal chief, possibly Mawedopenais, in 1870:

We are not afraid of the white man, the people whom you go to see in Red River are our Cousins as well as yours. So that friendship between us is but proper and natural. ${ }^{10}$

Given the timing of this meeting, only months after the execution of Thomas Scott and the creation of Manitoba, such a statement must be interpreted as a threat. Moreover, the Ojibway of the Northwest Angle demonstrated on multiple occasions their solidarity with the Métis, including the insistence that they be included in the terms of the final treaty.

When negotiations did at last open on September 25, 1873, the Ojibway arrived at the North West Angle Hudson's Bay Post "in procession, headed by braves bearing a banner and a Union Jack, and accompanied by others beating drums." ${ }^{11}$ This formal entrance was followed by a dance and the presentation of a peace pipe to Commissioner Morris.

The ceremonial entrance is a familiar device of diplomatic relations. The presentation of the Union Jack and the dance of honour offered a welcome to foreigners on Ojibway territory. Similarly, the pipe ceremony was likely of the kind intended "to

\footnotetext{
${ }^{9}$ Goffman, 426-28.

${ }^{10}$ Simon J. Dawson to Hector L. Langevin Dec 19, 1870, ADS, NAC CO 42/698 p.136

${ }^{11}$ Morris, 47.
} 
promote intertribal relations" ${ }^{12}$ and to mark the occasion as an important public event. Through these actions the Grand Council symbolically created a space for peaceful negotiations while simultaneously demonstrating its own strength and emphasizing the significance of the process. It also further emphasized that the land was "the Indian's house" in which the commissioners were guests. This impression was further amplified by the presence of a group of Ojibway estimated by the Manitoban at 800 people. Their camp was estimated at 100 tents, in contrast to the small group of commissioners.

Governor Morris stayed in the home of the Post officer, while the other commissioners and a few soldiers pitched tents around the large marquee that was set up for negotiations.

The Grand Council held its own meetings from September 26th to 29th, when the commissioners became frustrated and declared that negotiations must begin the next day or they would leave. On the 30th, however, the Ojibway asked for one more day. Representatives from Rainy River and Lac Seul arrived late, and the bands at Lac des Mille Lacs and Shebandowan had sent messengers to the Grand Council indicating that it was too far for them to come, but that they would accept the decision of the Grand Council. The fact that the commissioners were forced to wait for the Grand Council to open the negotiations is evidence of the strong bargaining position the Ojibway were in, and it is possible that some of the delay may have been intended to demonstrate this to the commissioners.

The formal negotiations opened on October 2 nd, $1873 .{ }^{13}$ Three chiefs were the principal spokesmen at the negotiations, although the larger body of twenty-four chiefs

\footnotetext{
${ }^{12}$ Sam D. Gill and Irene F. Sullivan, Dictionary of Native American Mythology (New York: Oxford University Press, 1992), 239.

${ }^{13}$ The date is given as the 1st in the Manitoban, but I follow the dating of Morris since it agrees better with the date on the actual treaty, which is the 3 rd.
} 
was consulted frequently. Chief Mawedopenais of Long Sault on the Rainy River ${ }^{14}$ acted as the principal spokesman for the Grand Council, assisted by Chief Powassin of the Northwest Angle ${ }^{15}$ and Chief Blackstone of Lac La Croix. ${ }^{16}$ These three men represented the three major geographical areas of the territory. The Grand Council opened by expressing hope that these negotiations would fulfill the promises made to them in the past. They refused to consider the treaty negotiations as beginning from a blank slate, which was what the commissioners wanted to do. Instead, they presented a framework that placed the current negotiations into an historical context, a necessary position considering Ojibway concerns about the trustworthiness of the commissioners. As the delegation in 1859 and Chief Blackstone in 1872 had done, the Ojibway leadership attempted to define the frame of the negotiations. In response to Governor Morris' statements that he had only limited authority to negotiate, the chiefs echoed Chief Blackstone's challenge to the powers of the commission.

Chief Mawedopenais then went on to explain the Ojibway relationship to the territory. This and the following quotes from these negotiations are translations recorded by a short-hand reporter for the Manitoban newspaper.

All this is our property where you have come ... This is what we think, that the Great Spirit has planted us on this ground where we are, as you were where you came from. We think where we are is our property. I will tell you what he said to us when he planted us here; the rules that we should follow - us Indians - He has given us rules that we should follow to govern us rightly. ${ }^{17}$

\footnotetext{
${ }_{14}$ Leo G. Waisberg and Tim E. Holzkamm, "We have One Mind and One Mouth. It is the Decision of All of Us": Traditional Anishinaabe Governance of Treaty \#3 (2001, accessed June 4, 2002); available from www.treaty3.ca/pages/TARR.html; Internet., 9.

${ }^{15}$ Morris, 321.

${ }^{16}$ Waisberg and Holzkamm, We Have One Mind, 9.

${ }^{17}$ Morris, 59.
} 
The chief confirmed the Ojibway right to the land based on the grounds that it was the action of the "Great Spirit"18 that placed them there and that they had followed the rules he laid out for them. Following Goffman's primary division of the world into the natural and the social, his statement suggested that their current way of life was a sociallyconstructed activity. ${ }^{19}$ A social activity carries with it a rationale and an ethos, as opposed to a natural activity, which is essentially ethically inert. Given that the Ojibway lived in the Rainy River and Quetico regions with divine approval, and given that they had maintained this approval through their own activities, ie: by 'following the rules', their relationship with the land differed significantly from that of mere travelers or settlers. This effectively amplified the value of their relationship to the particular territory in question. As discussed in Chapter Two, the Ojibway of this region were undoubtedly aware of Indian removal policies in the United States and of similar models being suggested for Canadian Ojibway people. They may therefore have wished to establish their rationale for remaining on their own territory at the outset.

Chief Mawedopenais attempted to relate this to the European experience by suggesting that they, too, had a particular place given to them by the Spirit "where you came from."20 This comment is at once an attempt to bridge Ojibway conceptions of homeland with European property values and at the same time an ironic comment on European expansionism. The implication is that the Europeans already had a territory of their own, and should not have been asking for more than they were given.

\footnotetext{
${ }^{18}$ Morris, 59.

${ }^{19}$ Since Goffman's definition of social activities is those perceived to be guided by intelligence, human or otherwise.

${ }^{20}$ Morris, 59.
} 
At this point the short-hand reporter may have left out some of the speech, for although the chief indicated that he was going to speak on the subject of the rules governing the Ojibway and their relationship with the land, this unfortunately was not recorded. Chief Mawedopenais went on:

I lay before you our opinions. Our hands are poor but our heads are rich, and it is riches that we ask so that we may be able to support our families as long as the sun rises and the water runs. ${ }^{21}$

In order to justify the amounts they ask for, the chief appealed to the governor to consider the poverty of his people. This is an example of a formal device that Janet Chute describes as "a traditional way of approaching a protector."22 It was not likely intended literally, however, since Waisberg and Holzkamm have presented evidence that game was abundant and the Ojibway were a thriving, vibrant culture in this period. ${ }^{23} \mathrm{He}$ also used frame bridging to remind the commissioners that the treaty negotiations would determine whether the Ojibway could continue to support themselves on the land. He added, cryptically, that "our heads are rich" - perhaps a reference to knowledge of the land, its stories and/or cultural practices. Given the rest of the sentence, it may also indicate knowledge of or desire for European "riches." Other Ojibway leaders used pleas of poverty to secure goods from government representatives in earlier negotiations, although descriptions of the people invariably point to their strength and health. ${ }^{24}$ Such statements are examples of a common Ojibway narrative form documented by Mary Black-Rogers and interpreted by her as a ritual expression of non-competitiveness. ${ }^{25}$

\footnotetext{
${ }^{21}$ Ibid., 61.

${ }^{22}$ Chute, 103.

${ }^{23}$ Leo G. Waisberg and Tim E. Holzkamm, "'Their Country is Tolerably Rich in Furs': the Ojibwa Fur Trade in the Boundary Waters Region 1821-1871," in Actes du Vingt cinqième congrès des Algonquinistes (Ottawa: Carleton University, 1994).

${ }^{24}$ For example, see Simon J. Dawson to Hector L. Langevin Dec 19, 1870, ADS, NAC CO 42/698 p.136.

${ }^{25}$ Black-Rogers, 366.
} 
The translator's use of the phrase "as long as the sun rises and the water runs" demonstrates his knowledge of the conventions of treaty negotiations, since similar phrases are found repeatedly in such meetings, to the point where they have become clichés. The chief may in fact have been citing a phrase used by one of the commissioners, who frequently inserted such images into their speeches in these meetings. This, too, may have had an ironic undertone. Irony would have served to communicate to Ojibway and Métis 'insiders,' and possibly to Simon Dawson, that the Ojibway were not entering into this discussion blindly. It would have reminded the audience of past interactions with Europeans and subtly transformed the power relationship between the two sides, at least from the perspective of the large group of Ojibway present.

The chief then contrasted the inference of poverty with the following image:

The sound of the rustling of the gold is under my feet where I stand; we have a rich country; it is the Great Spirit who gave us this; where we stand upon is the Indians' property, and belongs to them.[italics in original] ${ }^{26}$

The comment about gold was italicized by the Manitoban, perhaps an indication of the newspaper's interest in the treaty. Gold dust had been found in Shebandowan, north of the Quetico in 1871, and it was widely believed that there was gold in the Quetico, although this did not prove to be the case. ${ }^{27}$ In 1872 , Chief Blackstone had reportedly threatened to forcibly prevent gold prospecting activities in the Quetico. ${ }^{28}$ In directly addressing this belief, Chief Mawedopenais brought to the surface an underlying tension in the negotiations, again subtly transforming the balance of power. The chief re-

\footnotetext{
${ }^{26}$ Morris, 62

${ }^{27}$ Globe and Mail Oct 20, 1871 p.1 "Gold Fever at Fort Garry - Discovery at Lake Shebandowan - Great Excitement." The Quetico was described by Dawson as "the gold bearing country" in his official report to the Minister of the Interior (Morris, 328).

${ }^{28}$ Manitoban July 7,1872
} 
emphasized that the Ojibway territory was a gift from the Great Spirit, with its implication of rightful ownership. In addition, he contrasted the wealth of the country with the amount of money the Ojibway were asking for, demonstrating the fairness of their offer.

Mawedopenais then made an appeal to the needs of the descendants of the Ojibway and an emphasis on the solidarity and determination of the chiefs, both further examples of value amplification. He stated that "the white man has robbed us of our riches, and we don't wish to give them up again without getting something in their place." ${ }^{29}$ This nudged past events back onto the discussion table, despite the opposition of the governor, again demonstrating the importance of frame definition in the negotiations.

At this point in the proceedings the Lac Seul chief spoke for the first time. He indicated that his band was willing to sign the treaty, stating that he lacked the power to prevent the Canadians from using the land and waters. This too may have been a ritual expression of powerlessness, as theorized by Mary Black-Rogers and Janet Chute, or a recognition of the rapidly-shifting balance of power in the region..$^{30}$ He then went on to suggest that:

the time may come when I will ask you to lend me one of your daughters and one of your sons to live with us; and in return I will lend you one of my daughters and one of my sons for you to teach what is good, and after they have learned, to teach us. ${ }^{31}$

With this speech, the Lac Seul chief seemed to completely undermine the Grand Council's approach of solidarity and the demonstration of strength, pride and

\footnotetext{
${ }^{29}$ Morris, 62 .

${ }^{30}$ Black-Rogers, 368 and Chute, 103.

${ }^{31}$ Morris, 63.
} 
independence. Indeed, the governor was quick to exploit the opportunity, but the Ojibway were not so easily divided. Chief Blackstone indicated that he would need to go back to his territory and hold a council to consider the proceedings. This would have completely undermined the treaty, since it was already October and negotiations would then have been postponed until the following summer. Dawson responded to this threat by challenging Blackstone's authority and stating that the two bands at Shebandowan had already agreed to sign a treaty. This was a misinterpretation, and likely a knowing one, since Morris reported that the bands had only agreed that if a treaty were signed at this meeting, they would adhere to it. ${ }^{32}$ This implied a trust in the decisions of the chiefs, rather than a willingness to accept a treaty on any terms.

Rather than abandoning the negotiations altogether, the chiefs agreed to hold another Grand Council meeting. This interchange proved to be a turning point in the negotiations, and a settlement was reached the next day. In the final negotiations, the chiefs again made reference to "some poor Indians" ${ }^{133}$ and to "the poor man," ${ }^{134}$ using the familiar expressions of non-competition in their closing speeches. The terms of the treaty included a one time payment of twelve dollars per capita, an annuity of ten dollars per capita and fifteen hundred dollars per year in ammunition and twine for fishing nets. ${ }^{35}$ The treaty also allowed for reserves based on 640 acres for a family of five, compared to the 160 acres per family offered in Treaties \#1 and 2. The terms of the treaty reveal that the Ojibway had managed to obtain more generous terms than the negotiators of Treaties

\footnotetext{
${ }^{32}$ Morris, 54.

${ }^{33}$ Morris, 68.

${ }^{34}$ Morris, 71 .

${ }^{35}$ There were additional terms for chiefs and councilors, including extra annuities, clothing, flags and medals. Some details of the treaty as recorded by Morris are disputed by the Ojibway, who possess an alternate text known as the Paypom Treaty, based on the notes taken for Chief Powassin by Joseph and August Nolin.
} 
\#1 and 2. Indeed, the first two numbered treaties were subsequently amended to increase annuities in line with Treaty \#3, and subsequent treaty negotiations used Treaty \#3 as a benchmark. ${ }^{36}$ The Ojibway of the North West Angle thus succeeded in obtaining improved conditions not only for themselves, but for other Aboriginal people across the prairies.

The terms they had fought so hard for were destined to be broken repeatedly by the federal government. Although the Ojibway at first continued to use the strategies that had been successful for them in the past, they soon found that these were no longer effective. As discussed in Chapter Two, in 1894 the Sturgeon Lake band applied for but were refused an exchange of their reserve. They explained to the Indian agent that their current reserve was unhealthily close to stagnant water and that the fishing around it was inadequate to their needs. Their arguments, based on the need for food sources and a healthy environment, were supported by the Indian agent, who made a rare visit to the reserve that summer. Since the issues of health and food supply were directly in keeping with the federal government's mandate, the proposed move received approval from higher officials as well, but was smothered by Ontario civil servant Aubrey White's concern for timber sales. The Sturgeon Lake Band found its ability to negotiate nullified by the provincial government, which had an entirely different set of land values. This situation marked the beginning of a serious breakdown in Ojibway-government relations, one marked by a complete absence of common values that could be used to frame Aboriginal needs, values and beliefs.

${ }^{36}$ Dickason, 258-59. 


\section{Communications break down}

Given the conditions of their reserve, the Sturgeon Lake band had little choice but to use lands elsewhere, as indeed Governor Morris had assured them they could. ${ }^{37}$ When the Forest Reserve was established in 1909, therefore, the Ontario government found that there were Ojibway camping in Hunter's Island, south of the reserve. These people were forcibly removed, but again and again officials would discover Ojibway camps in the territory around the Sturgeon Lake reserve. The creation of Quetico Provincial Park in 1913 and the elimination of the Sturgeon Lake reserve quite predictably exacerbated the problem. Researchers Waisberg, Lovisek and Holzkamm have reported that,

Forest rangers thereafter expelled Indian families at gunpoint. Traplines and cabins were destroyed. Random shootings of "poachers" occurred. The Ojibwa were completely removed from a large part of their homeland. ${ }^{38}$

In the meantime, however, there were continuing appeals to government officials. Leo Chosa, an American Ojibway trader who worked in the Quetico region, wrote to protest the removal of the Sturgeon Lake people in 1910, commenting on the harshness of the winter, the lack of food and the vulnerability of the people. The image created by his letter is quite different from that of earlier texts. While this language had been used in previous negotiations, it had been balanced by threats of non-compliance, by frame bridging that aligned Ojibway needs with federal interests and responsibilities, and by frame amplification that confirmed the importance of the Ojibway relationship with the

\footnotetext{
${ }^{37}$ Morris, 70-71. At this point in the treaty process, the chiefs asked for and received confirmation that they would have the right to travel throughout the territory, "where it is vacant" and that they would be allowed to garden outside their reserves. The right to hunt and fish throughout the territory had been confirmed earlier (Morris, 58).

${ }^{38}$ Waisberg, Leo G., Joan A. Lovisek and Tim E. Holzkamm, "Ojibwa Reservations as 'An Incubus Upon the Territory': The Indian Removal Policy of Ontario 1874-1982" in Papers of the twenty-seventh Algonquian Conference (Winnipeg: University of Manitoba, 1997), 347.
} 
land. There are very few surviving examples of Ojibway political texts from the early twentieth century. Where they do exist, they are frequently second-hand reports submitted by Indian agents, who may simply have suppressed arguments they felt were unimportant, confusing or unlikely to impress the Ottawa office. The resulting impression is of an almost silent exile of Aboriginal people from the Quetico, an image marred only by the scattered reports of forcible removals and arrests.

By 1930, all the government-acknowledged members of Sturgeon Lake had been transferred to other bands, the Rainy River bands had been forced to consolidate, and many bands had agreed to large sales of reserve lands for timber extraction. Although the Lac des Mille Lacs band, to which some Sturgeon Lake Ojibway had been transferred, made a claim to the old reserve $24 \mathrm{C}$, this appears to simply have been ignored. Timber baron and MLA J.A. Mathieu had received his heavily discounted cutting licenses in the Quetico, and it appeared that Aboriginal rights had simply been forgotten. ${ }^{39}$

\section{"Sold down the river"}

The first evidence of a resurgence of Aboriginal claims to the Quetico came with the trapline agreements of 1948, which established fifteen traplines registered to members of the Lac La Croix band. In the 1960 's, the federal government began funding community development programs in north-western Ontario, such as the Amik

\footnotetext{
${ }^{39}$ Jim Mathieu, president of the Shevlin-Clarke Logging Company and Conservative MLA, managed to obtain licenses to cut in three areas of Quetico Provincial Park, at prices a fraction of the going rates. Ferguson privately sold Shevlin-Clarke one limit in 1917, and two more in 1919, for less than half their value, which was estimated at $\$ 2$ million. The Shevlin-Clarke logging area included the territory of the former Sturgeon Lake Reserve, but not of Hunter's Island, where the Sturgeon Lake had moved in 1910, nor of Lac la Croix. When his illegal transactions were exposed in 1921 after the election of the United Farmers government, he was vigorously defended by Ferguson. The story of the "Tory Timber Ring" is found in Nelles, 376. In a footnote on this page, Nelles explains that his accusations are based on two sources: the findings of the 1922 Timber Commission and an unpublished manuscript in the Ontario Archives, entitled "Timber wolves" written by an eyewitness to events in the Department.
} 
Association, to create economic opportunities for reserve communities. While these efforts focused on reserve lands, they also signaled a new way of speaking about land use and land rights, which became evident in the 1971 public hearings on the future of Quetico Provincial Park.

In 1971, to resolve environmental concerns about logging in Quetico Provincial Park, the Ontario government held a series of public meetings to discuss the topic. These were then used in the creation of a new, comprehensive park policy. Although there have been some changes over the years, this document remains the foundation of Quetico Provincial Park policy.

The Ojibway participated in this process in several ways. Although it is not explicitly mentioned in any of the reports, one of the members of the Advisory Committee for this process, Andrew Jourdain, was a member of the Lac La Croix band. Manitou Rapids band manager Willy Wilson made a formal presentation on behalf of the bands of the Rainy River district west of the Quetico. This was accompanied by a written brief, and Wilson also answered questions from the committee at the hearings. In addition, William Sault and Michael Linklater of the Union of Ontario Indians, Robert Handberg, owner of a resort and principal employer of Lac La Croix band members at the time, and Leonard Cadieux of the Amik Association all made presentations to the committee regarding Ojibway use of the park area.

The Ojibway chose an interesting blend of strategies to make their arguments. In essence, they wanted to ensure that their capacity to use the land and earn a living would not be compromised by park policies. Environmentalists, led by Bruce Littlejohn of the Algonquin Wildlands League (AWL), sought bans on logging, commercial fishing and 
trapping within the park. Hunting, of course, had been banned since the 1909 creation of the forest reserve. The AWL also opposed the expansion of roads into the area and the use of motorized vehicles, including boats, which were crucial to Ojibway guiding operations and necessary for transportation to the roadless Lac La Croix reserve.

An official brief was prepared and signed by the chiefs of six bands in the area, and a shorter version of it was presented as a speech by Willy Wilson. He began with the wry comment, "Why our interests were not looked after by the Department of Indian Affairs, organized for this purpose, we do not know ... no argument on our behalf was placed before your Committee by them, as far as we know." ${ }^{40}$ Wilson immediately established that the Ojibway had a historic, problematic relationship with the federal government, while suppressing the earlier role of the province in banishing the Ojibway from the Quetico. This was in keeping with the traditional practice of conflict avoidance, and made space for the possibility of a future partnership with Ontario. This necessary first step in the negotiation process established federal negligence as the cause of the current problem, which in turn implied the potential for a government-made solution.

Wilson then moved immediately to a clever frame transformation of the public perception of the Quetico. Referring to the government's proposed designation of the park as a "primitive area" (now called a "wilderness area") he commented that:

We are generally considered to be primitive people, yet no single section of land totaling a million and a quarter acres has been set aside for us in order that we may remain primitive. We seem to be able to foster this illusion on far smaller acreage of wilderness than it takes for the white man. ${ }^{41}$

\footnotetext{
${ }^{40}$ Public Hearings by and Briefs to the Quetico Provincial Park Advisory Committee, 4 vols, by S.G. Hancock, Chairman (1972) Volume 2: Toronto Hearings, 82. ${ }^{41}$ Ibid.
} 
In this play on the concept of "primitive" Wilson succinctly brought into question the ethics of the park proposal, the white settler concept of wilderness, and the pervasive racism of government land policies. He made use of the language of the emergent environmental movement to question its white, urban, middle-class underpinnings, a novel and radical critique for 1970 . Wilson thus based his argument not on criticism of goals or tactics but of fundamental philosophy. This type of challenge is required when the group seeking change does not have much in common with the audience they seek to sway. Since they cannot expect to appeal to common needs, they must instead appeal to their values and attempt to transform the audience's perception of the issue at hand to demonstrate its importance. ${ }^{42}$ Wilson continued this approach throughout the speech, stating for example that he was "speaking from the point of view of the poor and underprivileged," ${ }^{43}$ and that "we Indians would like to have the crumbs from the table."44

At another of the public hearings, Wilson challenged the environmentalists from another perspective, arguing that Aboriginal people were already concerned with resource conservation and were more than capable of preserving the wilderness character of the Quetico. In this speech he also questioned the idea of pristine wilderness, reminding the audience that "the Quetico Park that you are letting out right now is where most of our Indian people are making their livelihood." 45 The written brief expanded this argument, asking:

\footnotetext{
${ }^{42}$ Snow et al., 476.

${ }^{43}$ Public Hearings Volume 2: Toronto Hearings, 82

${ }^{44}$ Ibid., 85.

${ }^{45}$ Public Hearings Volume 2: Fort Frances Hearings, p. 78
} 
If it is still considered primitive, after having been used by our people for hundreds of years, and logged for over sixty years, is it not reasonable to assume that we can continue doing the same things, a certain acceptable amount of logging, trapping and fishing, without losing the primitive impact that the park has at the present time $[?]^{46}$

Wilson repeatedly presented the concept of a wilderness park in transformative images, challenging the audience to question their perceptions. In both the written brief and the transcribed speech, there is plentiful evidence of the "predominant ironic mode" common in post-colonial literature. ${ }^{47}$ The brief used stereotypical language, such as being "low on the totem pole, ${ }^{n 8}$ suggesting that the Ontario government was "misreading their smoke signals"49 and taking away the land "without even an exchange of beads." ${ }^{150}$ Through these images the Ojibway subverted popular perceptions of Aboriginal people to expose abuses of power, poor logic and unethical decision-making. For example, the phrase "low on the totem pole" was used to emphasize a statement that Aboriginal needs were consistently ignored, and that the Ontario government had repeatedly refused to grant the bands small timber limits.

This brief, prepared in consultation with many bands in the area and signed by six chiefs, is the first major written declaration of Ojibway land rights in which humour appeared as a consistent feature. This may be because many of the earlier speeches appear in translation, and many nuances of the speakers' words have likely been lost.

Wilson's speeches and the brief went far beyond the traditional format in their demonstration of powerlessness and need. As well as suggesting that he was "speaking from the point of view of the poor and unprivileged," Wilson described the treaty-makers

\footnotetext{
${ }^{46}$ Public Hearings Volume 1: Brief, Rainy River Indians, p.3

${ }^{47}$ Ashcroft, Griffiths and Tiffin, 28.

${ }^{48}$ Public Hearings Volume 1: Brief, Rainy River Indians, p.6

${ }^{49}$ Ibid., 3.

${ }^{50}$ Ibid., 2.
} 
as "outnumbered and gentle, unlearned people." ${ }^{n 1}$ The Quetico he described as "a cold land and a harsh land" with "few ways to make a living," in which the band members "try to survive." 52 Finally, in the question and answer section, Wilson commented that "we have such little voice." ${ }^{53}$ The brief included many more images of the distorted power relationship between the Ojibway and the government. The chiefs asked at one point, "Are we once again to be victims, sold down the river for a mess of pottage?" This was in sharp contrast to the treaty negotiators, whose approach had been to emphasize their position of strength. The new strategy amplified the values of equality and generosity to generate a public interest in the position of the Ojibway.

These texts reflect both the actual changes in Aboriginal life in the Quetico region and an increasingly subtle understanding of settler values. Whereas the Ojibway of 1873 had argued for their rights, in 1971 their descendants appealed to a very different settler perception of Aboriginal people. Rather than basing their claims on rights and a shared need for honesty, they increasingly appealed to the "Canadian" values of justice, equality and, above all, mercy. In their introduction, they implicitly questioned the relationship between these values and the history of government-Aboriginal relations. Their presentations suggested that the Park Advisory Committee had an opportunity to redress past wrongs, and played to the settler self-perception as charitable benefactors.

As the base of their claim, the written brief simply stated that "this area ... is our home. Our ancestors lived here long before the white man came to this country." Justice and land rights remained the foundation of the Ojibway claim to the land. In contrast to the treaty, however, there was no reference to the land as a gift to the Ojibway.

\footnotetext{
${ }^{51}$ Public Hearings Volume 2: Toronto Hearings, p. 82

${ }^{52}$ Ibid.

${ }^{53}$ Ibid., 88.
} 
What did appear, however, was a sharp criticism of the argument made by the AWL. In his speech to the committee, AWL spokesman Bruce Littlejohn referred to the Quetico as "a wilderness sanctuary " and a "holy ground" which could provide "spiritual comfort" to urban people. ${ }^{54}$ The Ojibway response was scornful:

We suggest that such a source of spiritual comfort would seem ill-founded if it is achieved by depriving a livelihood to those dependent on its natural resources. Let those in need of such comfort, dwell upon the undeniable fact that practically all of Northwestern Ontario contains miles and miles of primitive forest, accessible by canoe, upon which their thoughts can be focused in awe and wonder. Our needs are more immediate. Given the opportunity for the physical comfort that accompanies a full stomach, an adequate roof over our heads, and clothes to keep us warm, perhaps we too, will derive comfort from spiritual thoughts. ${ }^{55}$

The whole question of a spiritual connection to the land, whether Ojibway or settler, was therefore subordinated to material, economic concerns. At the same time, when asked directly about the "cultural and historical significance" of the Quetico to the Ojibway, Wilson answered, "Definitely, I think it is still seen as a spiritual ground." 56

While the AWL succeeded in its campaign to ban logging in the Quetico, the Ojibway managed to maintain their traplines, some use of motor boats, and limited fishing rights. The park policy was completed in 1978, and although policy documents in the 1980 's often stated the elimination of traplines as a goal, it has never been implemented. The Ojibway seemed to have succeeded in obtaining some limited leverage with the province through a transformed concept of wilderness and the amplification of equality and generosity as Canadian values.

\footnotetext{
${ }^{54}$ Ibid., 4.

${ }^{55}$ Public Hearings Volume 1: Brief, Rainy River Indians, p.5

${ }^{56}$ Public Hearings Volume 2. Toronto Hearings, p.86
} 
In 1991, when Ontario Minister of Native Affairs Bud Wildman offered an official apology to the people of Lac La Croix and Sturgeon Lake, the Lac La Croix chief took a very different approach. For the first time in a public forum, the chief openly expressed anger towards the governments. He stated that the Ontario government's actions in the Quetico had resulted in deaths and had "grievously hurt the people of Lac La Croix, both collectively and individually."'Ontario apologizes to Indians"57 $\mathrm{He}$ also blamed the federal government for having "utterly failed to fulfill its fiduciary obligations." In his list of the impacts of government policies, he also included for the first time a complaint that officials had "prevented them [members of the two bands] from visiting sacred ceremonial grounds." This accusation was picked up by Gerald Killan and incorporated into his history of Ontario parks. ${ }^{58}$ The public apology was followed by amendments to the Quetico Management Plan to allow the Lac La Croix First Nation increased use of motorboats and aircraft for the purposes of guiding, still a major source of income to the community.

\section{"Free and unfettered access"}

The 1990's also saw the Grand Council undergo a renewal process and begin to reclaim its authority. In 1996, an assembly of Treaty \#3 chiefs and a council of elders agreed to a policy on the "renewal of Anishinaabe governance." ${ }^{59}$ In 1997, the Grand Council and the Minister of Indian Affairs signed a framework agreement that laid the foundations of a new negotiation process with the federal government that would "give

\footnotetext{
57"Ontario apologizes to Indians" Globe and Mail June 4, 1991, A2

${ }^{58}$ Killan, 25.

${ }^{59}$ Grand Council Treaty \#3 "Bimiiwinitisowin", 3.
} 
meaningful expression to the spirit and intent of the Treaty \#3." ${ }^{60}$ Extensive community consultations since that time have resulted in the development of a model for a transitional government structure. This process has recently been interrupted by the federal government, which cut its funding to the Grand Council in September 2002 and broke off negotiations on self-government in November. ${ }^{61}$

The Grand Council's governance proposal, Bimiiwinitisowin Omaa Akiing, is a self-government proposal based on the treaty itself as well as spiritual and cultural traditions. Relating governance directly to land rights, the proposal asserts the need for "free and unfettered access to the territory."62 In this proposal Grand Council has employed a familiar postcolonial strategy, the insertion of words in the language of the "other" - in this case Ojibway - in order to emphasize the untranslateability of a key concept. The English concept of governance, the title implied, cannot fully encompass Bimiiwinitisowin. Furthermore, the phrase omaa akiing suggests a different relationship with the territory than would the English "on our land." This strategy establishes the governance proposal as specifically Ojibway in form, implying a link to traditional governance which is detailed in a separate research paper. ${ }^{63}$ It denies the feasibility of a government-made solution and encourages cultural cohesion and solidarity.

In 2002, however, the introduction of the First Nations Governance Act (FNGA), despite its promise to "not affect Aboriginal or treaty rights or self-government negotiations," ${ }^{64}$ was greeted by many Aboriginal leaders as a serious threat to those very

\footnotetext{
${ }^{60} \mathrm{Ibid}$.

61"Stall on approved government funding", Kenora Daily Miner and News, Sept 9, 2002 and "Federal government pulled the plug", Kenora Daily Miner and News, Nov 4, 2002.

${ }^{62}$ Grand Council Treaty \#3, "Infrastructures".

${ }^{63}$ Waisberg and Holzkamm, We Have One Mind.

${ }^{64}$ Robert Nault, "First Nations Governance Act: Message from the Minister [document on-line],"accessed April 10, 2003; available from http://gpn-fng.ainc-inac.gc.ca/FNGA_e.asp\#msg.
} 
rights. The Grand Council for Treaty \#3 was among those which responded promptly to the bill, explaining the differences and contradictions between the FNGA and its own governance initiative in a document dated June 19, 2002, only five days after the introduction of the bill. As in the negotiations over Quetico Park, irony pervades the Grand Council's reaction to the FNGA. Although it may superficially appear to be "what the doctor ordered," the Grand Council suggests that "upon closer scrutiny"the FNGA is merely "another piece of legislation being forced on us," continuing the tradition of "years of colonialistic legislation." ${ }^{65}$

The Grand Council has adopted an assertive and resolute approach in this round of discussions on the subject of governance. This impression is borne out by the actions the Grand Council and Grand Chief have taken, such as organizing protests of the FNGA in Indian Affairs Minister Robert Nault's home riding of Kenora. The Grand Chief is no longer using the traditional strategy of portraying himself and his people as nonthreatening, but instead is employing a contrary strategy, refusing to compromise and using demonstrations of strength to back up his arguments. He has been careful to distance himself from militant actions such as those employed in the 1990 standoff at Oka, emphasizing the nonviolent nature of the protests. ${ }^{66}$

At the same time, however, he is suggesting that the federal government is provoking Aboriginal people into increasingly radical action. In a May 2003 press release, the Grand Chief is quoted as saying:

\footnotetext{
${ }^{65}$ Grand Council Treaty \#3, "Where is Bimiiwinitisowin Omaa Akiing standing in relation to INAC's initiative? [report on-line]" accessed July 12, 2002; available from www.treaty3.ca/pages/gov_init.html ${ }^{66}$ For example the press release for the May 15, 2003 rally against the FNGA stressed that "Jourdain is taking every step to ensure that the march is peaceful." Grand Council Treaty \#3, "Jourdain concerned that Nault is sowing the seeds of conflict [press release May 8, 2003]" accessed May 15, 2003; available from www.treaty3.ca/pages/mediarelations.php.
} 
The Ministers [sic] arrogance, insults and confrontational approach is stirring the pot and I can see that people are becoming more and more frustrated and fear that people will rise-up to say enough - it's certainly something I am sensitive to and I hope that we will see a dramatically different approach from the Government soon, until then I will promote legitimate expressions of democracy and protest. ${ }^{67}$

The Grand Chief also made a presentation to the Turtle Island Forest Conference in May 2003 in which he proposed that:

[I]f we don't very quickly make some fundamental changes to how forests are protected and managed in this Country, including respect for the Creator's law and Aboriginal law as well as Crown law, and including revenue sharing and cooperative management with Aboriginal peoples, Canada is going to be very embarrassed at the World Forestry Congress in September. ${ }^{68}$

This is the most explicit use of Noel Dyck's "politics of embarrassment" to date by a leader from the Quetico region. At the same time that the Grand Chief made this threat, he also aligned himself with traditional Ojibway values through his appeal for "respect for the Creator's law," which is another of the strategies noted by Dyck, the appeal to cultural conservatism. The importance of cultural survival, implicit in the treaty negotiations as argued by Chamberlin, has now become a matter for explicit political strategy after a century and a half of colonialism. Whereas leaders at the time of the treaty negotiations may have considered such concerns as non-negotiable, at the beginning of the twenty-first century the need to struggle for cultural survival is evident. Attempts to inscribe a nationalist history onto the Quetico and to claim it as a spiritual sanctuary for the settler culture may have reinforced the threats to Ojibway culture in the region.

\footnotetext{
${ }^{67}$ Ibid.

${ }^{68}$ Leon Jourdain, Natural Resources Revenue for Aboriginal Peoples: An Alternative to Genocide, speech to the $9^{\text {th }}$ National Forest Congress [May 1-2, 2003], accessed May 15, 2003; available from http://www.turtleisland.org/front/_front.htm, 9.
} 
The Lac La Croix First Nation has also been involved in negotiations with the Quetico Foundation, an organization created in 1954 to oversee and promote Quetico Provincial Park. The Lac La Croix First Nation recently succeeded in persuading the Quetico Foundation to stop using images of pictographs in its promotional materials, which the Foundation had been doing since its inception. Citing the "sacred value" of the pictographs, the Quetico Foundation now asks visitors to consider leaving an offering of tobacco, sage or cedar when they visit. ${ }^{69}$ Until September 2002 , it seemed that the federal government had embarked on a similar mission of fence-mending. In 1998, a statement by the three regional chiefs of the Grand Council noted that "lately, Canada seems to have turned away from its attempt to destroy our heritage. ${ }^{170}$

In response to the introduction of the FNGA, the funding cuts and the breakdown of self-governance negotiations, there have been suggestions of new strategies for the Grand Council. In addition to the rally against the FNGA in Minister Nault's riding, the Grand Chief is supporting the members of the Grassy Narrows First Nation in their campaign against logging on their territory, which began in December $2002 .^{71}$ When the roadblocks were established in December, the Grand Council released a statement with the headline "Grand Council Treaty \#3 writes off Bob Nault"72indicating that it will simply wait to negotiate with his successor. More recently, the Grand Council put out another press release, this one entitled "Jourdain concerned that Nault is sowing the seeds

\footnotetext{
${ }^{69}$ Quetico Foundation

${ }^{70}$ Treaty and Aboriginal Rights Research, "We Have Kept Our Part of the Treaty": The Anishinaabe Understanding of Treaty \#3 [report on-line] (1998), accessed June 4, 2002; available from www.landclaimsdocs.com/conferences/Quebecpdf/GrandCouncilTreatyNo.3final.pdf, iii. ${ }^{71}$ Grand Council Treaty \#3, "Treaty \#3 Grand Chief Supports Grassy Narrows Action [press release December 3, 2002]" accessed February 4, 2003; available from www.treaty3.ca/pages/mediarelations.php. ${ }^{72}$ Grand Council Treaty \#3, "Grand Council writes off Bob Nault [press release December 11, 2002]" accessed February 4, 2003; available from www.treaty3.ca/pages/mediarelations.php.
} 
of conflict." ${ }^{73}$ In these and other media documents, the Grand Chief and council are directly confronting INAC and identifying Minister Nault as personally responsible, taking advantage of the fact that they are in his home riding and therefore have the potential to damage his political chances of re-election.

While this confrontational approach has been out of favour for a long time, it recalls the dramatic strategies of Chief Blackstone. Given the increasingly subtle understanding of mainstream political and social values that contemporary Treaty \#3 leaders have, such an approach may prove more difficult to derail than it was for the nineteenth century treaty commissioners. As in the 1870 's, the federal government may find that the Ojibway are stubborn negotiators with a diversity of strategies and a willingness to wait out their adversaries.

${ }^{73}$ Grand Council Treaty \#3. 


\section{CHAPTER FOUR}

\section{"AN ORDERLY WHITE PRESENCE": GOVERNMENT STRATEGIES}

This chapter concentrates on governmental strategies and tactics, examining the other side of the negotiation process. This will involve a consideration of policy development and the strategies employed to obtain public approval and Aboriginal consent. Frame theory will again provide the starting point for this analysis of political strategies as expressed in words and actions. In addition, I will draw upon the ideas of other writers to clarify the context within which policy decisions have been made, the philosophical underpinnings of Indian Affairs policy, and the relationship between the federal and provincial governments.

Although Snow et al. developed their model of frame alignment for the analysis of social movements, Ponting and Symons have successfully applied it to government strategy as well. As they explain, when the definition of an event or process is contested, the process of frame alignment that ensues is fundamentally interactive; while the concept of framing has been primarily applied to the analysis of alternative discourses, the process of defining a situation as problematic occurs in interaction, not in isolation. ${ }^{1}$ Moreover, such an alignment process may go through multiple iterations, as indeed has been the case in claims to the Quetico. Over time, therefore, the Ojibway discourse on

${ }^{1}$ Ponting and Symons, 207. 
land values has evolved in response to government and public opinion, and conversely, government and public narratives have adapted in response to Ojibway arguments.

The interactive nature of frame alignment produces what may be considered a fifth strategy, which is suppression. ${ }^{2}$ This often appears as a corollary to amplification, and indeed may be required to successfully amplify values or beliefs. Suppression can be considered a significant political strategy in its own right, however, especially when there is a dramatic difference in political power between adversaries, as there is in this case.

I will use frame theory in this chapter to draw out some specific government framing strategies and identify changes to these through time. In addition, I will consider the gaps between language and action and between federal and provincial policies. Since these have been studied by many other writers, however, this discussion will be limited as far as possible to the specific case of the Quetico area and the impact on Ojibway use and occupation of their territory.

\section{The Development of Indian Policy in Canada}

Indian policy in Canada originated with British civil servants in the eighteenth century, who advocated measures that they believed would simultaneously pave the way for colonization and at the same time offer some measure of protection from its impact on Aboriginal peoples. By the time of Confederation, this approach was deeply entrenched, and the tension between its two somewhat contradictory principles was eased through the development of the theory of assimilation. This postulated that Aboriginal peoples would either be rapidly absorbed into the mainstream Canadian public, which was referred to as

\footnotetext{
${ }^{2}$ As discussed in Chapter One, the four strategies of frame alignment proposed by Snow et al. are frame bridging, amplification of beliefs or values, extension and transformation.
} 
advancement, or alternatively that they would die out. In either case, assimilation made it feasible to promote rapid colonization and install presumably temporary measures to protect Aboriginal nations that were assumed to be only a generation or two away from disappearance. To buttress this theory, the federal government began to create legal definitions of "Indians" that restricted the numbers that could claim any governmental protection. $^{3}$

As a framing device, assimilation was used as a bridging and amplification device to create links between the contradictory policies of eliminating Aboriginal rights and culture while protecting Aboriginal individuals. The British and Canadians framed their refusal to acknowledge Aboriginal land rights in terms of cultural evolution, adopting as fact the speculative theories of early anthropologists such as Herbert Spencer. ${ }^{4}$ The ethnocentrism of cultural evolutionary theory is readily apparent to the modern eye, but government officials did not restrict themselves to a crude claim of superiority. In their creation of the new ideal of Aboriginal assimilation, they amplified the value of order and suppressed questions about the future of Aboriginal peoples and their cultures.

With Confederation, the development of a coherent and comprehensive Indian policy became a priority. The British North America Act specified that "Indians and lands reserved for Indians" were to be a federal responsibility, while lands and forests were provincially-controlled. This mechanism, established to provide the provinces with a major source of revenue, subsequently created many difficulties for Aboriginal peoples, of which the Quetico situation is only one example.

\footnotetext{
${ }^{3}$ Dickason, 238.

${ }^{4}$ Roger Gibbons, "Historical Overview and Backgound: Part I," in First Nations in Canada, ed. J. Rick Ponting (Toronto: McGraw Hill Ryerson, 1997), 25.
} 
Indian Affairs had been regulated by the Colonial Office prior to Confederation, and the new title of Superintendent-General of Indian Affairs was initially held by the Secretary of State. In 1873 , the title was passed over to the Minister of the Interior. While these ministers held political authority over the Ojibway, the day-to-day decisions that had most obvious impacts on their lives were generally made by Indian agents or their superiors, civil servants in Winnipeg and Ottawa.

In Indian policy, the desire for order and the fear of chaos are evident throughout; I suggest that order has in fact been the guiding principle of Indian policy throughout Canadian history. The idealization of order, conflated with industrialization, was contrasted with the demonization of chaos, associated both with nature and Aboriginal peoples. ${ }^{5}$ Order came to be associated with agriculture, with literacy and written laws, and of course with Christianity. The underlying question has always been, which policies will best create and preserve order? The responses have depended largely on the perceived threats to order: nomadic and semi-nomadic land use patterns, cultural pluralism, political unrest and disease have been among the most prominent. Policymakers have therefore attempted to preserve order through the control, or ideally the elimination, of these factors. This has led to policies emphasizing the following: the introduction of agriculture and later industry to Aboriginal communities; education programs such as residential schools, designed to eliminate Aboriginal cultures; the suppression of Aboriginal medical and religious practices; the marginalization of Aboriginal political organization; and the introduction of Western medicine and religion. ${ }^{6}$

\footnotetext{
${ }^{5}$ Razack, 2-3 and Chamberlin, 30.

${ }^{6}$ Some discussions of the desire for order vs, chaos in Canadian Indian policy include Chamberlin, 3-37 passim, James (Sákéj) Youngblood Henderson, "Postcolonial Ghost Dancing: Diagnosing European Colonialism," in Reviving Indigenous Voice and Vision, ed. Marie Battiste, (Vancouver: University of British Columbia Press, 2000), 58 and Razack, 2-4. The early twentieth century description of the
} 


\section{Indian Policy in the Quetico}

As discussed in Chapters Two and Three, the survey of the Red River Road led to the first significant discussions of political relations between the North-West Angle Ojibway and the Canadian government. The Ojibway appealed to the European understanding of land rights using the metaphor of the land as a house, which must be entered openly through the front door. Their insistence on a discussion with the Europeans clarified the importance of the issue for the Ojibway, and they implied that the Canadians were attempting to enter their land "through the window" - as a thief does.

The Canadians acknowledged the concerns of the Ojibway through their agreement to a meeting, although they may have been persuaded by the greater numbers and arms of the Ojibway party. Expedition member Simon Dawson did repeat the house metaphor in his report, however, indicating that he took the Ojibway argument seriously. The persistence the federal government later showed in treaty negotiations may be a further demonstration of this acknowledgment, for Treaty $\# 3$ is certainly not among those negotiations of the period now recognized as having been organized to exclude Aboriginal participation. Furthermore, the attempts to demonstrate honesty and openness found in the opening speeches of the 1873 negotiations may reflect the concerns raised in 1859 , since Dawson himself was a major figure in both meetings.

In Chapter Three, I touched upon the significance of the process of treaty negotiation, and it seems fitting to return to that point here. J. Edward Chamberlin discusses the significance of British values in the negotiation of treaties in this period. In

Ojibway as "an incubus upon the territory" reveals the persistence of this view (Provincial Treasurer, December 13, 1905, quoted in Leo G. Waisberg, Tim Holzkamm and Joan Lovisek, "Ojibwa Reservations as 'An Incubus Upon the Territory': The Indian Removal Policy of Ontario 1874-1982," in Papers of the twenty-seventh Algonquian Conference, Winnipeg: University of Manitoba, 1997). 
particular, he points to the contrast between the Canadian and American approaches to Aboriginal peoples. While the United States declared an end to negotiation with Aboriginal peoples in 1871, the Canadian government emphasized their British heritage with appeals to fair play, responsibility and honesty. The British self-perception as a superior race was transformed in the Canadian context into a program of protecting, advancing and assimilating Aboriginal peoples. ${ }^{7}$ The contradictions inherent in these concepts were swept away in the assumption that superior European cultures would by necessity overwhelm and supplant inferior Aboriginal ones. In order to emphasize their difference from the Americans, therefore, the Canadian government "was ostentatiously acknowledging the political and cultural status of Indian nations, ${ }^{88}$ while at the same time working to restrict and ultimately eliminate their real political and cultural autonomy. This contradictory behaviour is clearly evident in the negotiation of Treaty \#3.

\section{A "powerful Indian community"}

The failure of the attempts to negotiate a treaty in 1871 and 1872 were not much discussed by the commissioners. Alexander Morris commented simply that the Ojibway were "found not to be ready for the making of the treaty." Although this could be interpreted as meaning that the Ojibway were unprepared for the negotiations, the 1872 newspaper reports suggest that they were actively resisting negotiating under the conditions the commissioners wished to impose..$^{10}$ It is also quite possible that the negotiations failed at least in part because the original Indian Commissioner appointed by

${ }^{7}$ Chamberlin, 28.

${ }^{8}$ Chamberlin, 36 .

${ }^{9}$ Morris, 45.

${ }^{10}$ In particular Chief Blackstone's attempt to bypass the Commission and negotiate with Ottawa directly. 
the government was Wemyss Simpson, a man known to the Ojibway as both a whiskey seller and as part of what Janet Chute calls "a powerful clique" that opposed Ojibway land rights at every turn. ${ }^{11}$ This lends credence to the story told of Simpson's opposition to Chief Blackstone. As discussed in Chapter Three, Blackstone attempted to build a coalition of chiefs to travel to Ottawa to discuss the treaty process. Simpson not only used the trader and Indian agent Robert Pither to undermine Blackstone's efforts, he took the far more serious step of issuing a travel ban, forbidding any ferry operator from taking him across Lake Superior "by order of the Indian Department."

This is the context in which the negotiations for Treaty \#3 opened, with the Ojibway essentially forced into accepting the colonial treaty process, although they continued to demonstrate considerable strength in the negotiations. Commissioner Dawson, however, preferred to emphasize the history of friendly relations with the Ojibway, and emphasized in particular his personal relationship with them. He also characterized the Ojibway's hospitality to the early traders as indicative of loyalty to the British Crown, using this image to suggest a long history of the Ojibway as "true and loyal subjects,"12 a position that conflicted with the Ojibway's self-perception as independent people. This is in keeping with Chamberlin's assertion that honesty and fair play were prominent values in government negotiations.

Alexander Morris, Lieutenant Governor of Manitoba, acted as chief commissioner and published the reports on the treaty negotiations. He presented himself as impressing a divided and jealous people with his strength of mind. This is demonstrated in several reported incidents, such as his refusal to move the proceedings to Fort Frances and his

\footnotetext{
${ }^{11}$ Chute, 148

${ }^{12}$ Morris, 55.
} 
apparently successful strategy of threatening to negotiate with individual bands if the Grand Council did not accede to his proposal. At the same time, he acknowledged that negotiations were "protracted and difficult"13 - complications caused by the fact that the Ojibway were well-organized, consistent in their demands and largely independent of the government.

Indeed, a recent study of food sources and the fur trade in the nineteenth century indicates enduring Aboriginal autonomy. Hudson's Bay Company traders and government officials found themselves unable to dictate conditions of trade to the Ojibway, whose diverse sources of food and furs remained viable throughout the nineteenth century. ${ }^{14}$ Dawson's words echoed the sentiments he expressed in his government reports, in which he portrayed the Ojibway as simultaneously a "powerful Indian community"15 but also "[m]inors under the care and protection of the Government." ${ }^{16}$

Chamberlin has also argued that both the Ojibway and the commissioners shared the common goal of preserving their cultures and traditions, and that this was the underlying goal of the treaty process for both sides. In this sense, both the Ojibway and the Canadian government sought order through the treaty process. Chamberlin argues that the great flaw in the treaties was not in their negotiation, but rather in the subsequent interpretation of their meaning and in what he calls "our pernicious habits of crediting written texts more than oral." ${ }^{17}$ While this does not address the very real conflict between Áboriginal and industrial Canadian land uses, it does point to the importance of

\footnotetext{
${ }^{13}$ Morris, 45.

${ }^{14}$ Waisberg and Holzkamm, "Tolerably Rich", 498-499

${ }^{15}$ Simon J. Dawson to Hector L. Langevin Dec 19, 1870, ADS, NAC C.O. 42/698, 126.

${ }^{16}$ Ibid., 138

${ }^{17}$ Chamberlin, 16.
} 
continuously negotiating the meaning and significance of treaties and other agreements between different cultures.

The Canadian government came to the 1873 negotiations with a precise intention. While the Ojibway emphasized a process of negotiation aimed at protecting their way of life, the goal of the commissioners was to obtain signatures on a document that would allow the government to use the territory without interference. Therefore they agreed that Ojibway land uses could continue without holding a serious discussion of the possible impacts on the Ojibway and their land of resource extraction and settlement. They did not consider the possibility of restricting settler activities to allow the Ojibway to practice traditional harvesting activities, nor did they take into consideration the impacts of development projects such as roads and dams on Ojibway hunting and fishing grounds.

In accord with its own interests, the government preferred to consider neither the past nor the future, but to concentrate exclusively on the present. Questions regarding Ojibway traditions and cultural survival were therefore treated superficially. It is perhaps redundant to mention that the commissioners assumed an intellectual and cultural superiority to the Ojibway, although this was initially tempered by their recognition of the Ojibway's military strength. Despite their own policy background, which argued that Aboriginal peoples required protection from invasive settlement, the commissioners did not take seriously Ojibway concerns about their hunting and fishing territories. Simon Dawson himself had suggested in 1870 that colonial activities were likely to reduce the number of game and destroy the sturgeon fishery in the region. ${ }^{18} \mathrm{He}$ also noted at that time that the cost of annuity payments and reserves "cannot be considered great in

\footnotetext{
${ }^{18}$ Simon J. Dawson to Hector L. Langevin,Dec 19, 1870, ADS, NAC C.O. 42/698, 142-43.
} 
comparison to the probable future value of the Country." 19 However, when Mawedopenais suggested that Canadian activities were drastically reducing the number of fish in the Rainy River, the Governor refused to address his concerns. ${ }^{20}$ Matters such as language and religion, central to cultural survival, were not discussed by either side. On the subject of cultural sovereignty, Chamberlin argues that "the treaties are silent on such matters not because they were unimportant but because compromise on them was inconceivable. They were inviolate, and non-negotiable." ${ }^{12}$ Even if these subjects had been raised, however, it seems likely that they would have been met with the same dismissive attitude the commissioners demonstrated on the matters of access to hunting and fishing territories. Even Dawson, the most sympathetic member of the commission, believed that a treaty should require the Ojibway to give up "all the Territorial rights which they assume to hold." 22

Both the federal and Ontario governments saw the land of the Treaty $\# 3$ area primarily in terms of its resources, and both believed that government control was necessary to prevent what is now called 'the tragedy of the commons.' In keeping with their concern for order, they believed that government ownership and private use, regulated and controlled by themselves, would lead to the most organized and efficient use of natural resources. In contrast, common ownership was framed as primitive and wasteful, leading to the 'tragedy' of uncontrolled exploitation of resources. Many, including the Ontario government, questioned whether common ownership was even legally valid. This was not, however, a position they expressed openly to the Ojibway,

\footnotetext{
${ }^{19}$ Ibid., 143.

${ }^{20}$ Morris, 74

${ }^{21}$ Chamberlin, 7.

${ }^{22}$ Simon J. Dawson to Hector L. Langevin, Dec 19, 1870, ADS, NAC C.O. 42/698, 140.
} 
who held the contradictory view that common ownership was not only possible but ideal. Moreover, the federal government needed to acknowledge the validity of common ownership to make the treaty process valid, although it was careful to be as vague as possible. Dawson's expression "the Territorial rights which they assume to hold" is a typical federal statement on Aboriginal land rights in the nineteenth century.

Since assimilation was the primary goal of federal Indian policy at this time, the commissioners likely believed that the Ojibway would require only short-term compensation and protection. Although the commissioners were careful never to suggest to the Ojiibway themselves that they were a disappearing people, studies of federal Indian policy and policy-makers reveal that this was a dominant assumption in the period. ${ }^{23}$ Federal acts passed in 1868 and 1869 had made assimilation official government policy, in advance of the 1876 Indian Act. Governor Morris and Commissioner Dawson would have been well aware of these recent policies.

Despite the fact that Morris' report gives the impression that he rejected the Ojibway requests for compensation for past incursions onto their land, the negotiations of the following two days did in fact cover some outstanding issues. Among these were the relocation of an $\mathrm{HBC}$ post and reimbursement for logging and other damage to the land. While overtly they framed the negotiations as beginning with a blank slate, the actions of the Commission made it clear that they in fact accepted, to some degree, the value the Ojibway placed on the resolution of past disagreements and the demonstration of honesty.

$\overline{{ }^{23} \text { Asch, 26; Dickason, 237; }}$ Gibbons, 25. 
Both Dawson and Morris also employed the tactic of undermining Aboriginal authority in order to secure an agreement. Morris threatened to bypass the Grand Council and treat directly with local chiefs, magnifying the insult with a suggestion that the Grand Council representatives had put on a deceptive show of unity. This was a direct challenge to Ojibway values. Furthermore, when Lac La Croix Chief Blackstone objected to the Governor's strategy of divide and conquer, indicating that he wished to return home to hold a council, Dawson reacted by challenging his authority.

Did the band at Shebandowan - did Rat McKay, authorize him to speak for them? Ke-hake-ge-nen is Blackstone's own Chief, and I am perfectly willing to think that he authorized him. What I have to say is that the Indians may not be deceived by representations made to them, and that the two bands met me at Shebandowan and said they were perfectly willing to enter into a treaty. ${ }^{24}$

This strategy has proven to be among the most enduring techniques for undermining Aboriginal authority when it threatens to assert itself. In this case, as discussed in Chapter Three, Dawson was either inaccurate or dishonest in his statement about the Shebandowan bands, leaving out the key fact that the bands had expressed their trust in the Grand Council to negotiate on their behalf. This by no means translates into an acceptance of any treaty the government decided to put forward, as Dawson implied.

The Governor also employed a strategy of expressing pity for the Ojibway, and especially for their children, if they rejected the terms of the treaty. "If we do not succeed today I shall go away feeling sorry for you and for your children that you could not see what was good for you and for them, ${ }^{125}$ he stated in his opening speech. He exhorted the leaders to "[think] of those you have left at home, and also of those that may be born

\footnotetext{
${ }^{24}$ Morris, 64.

${ }^{25}$ Ibid., 61.
} 
yet, ${ }^{26}$ and made similar comments throughout the proceedings. In this he attempted to equate responsible leadership with adhesion to the treaty, making use of the value the Ojibway placed on personal responsibility.

Outside of negotiations, government representatives described the territory in very different terms from the Ojibway. While the Ojibway referred to particular areas in terms of their value as hunting, fishing, gathering or gardening places, the settlers focused on three major values in the treaty-making period: proximity to the United States boundary, access to the West, and natural resources.

Although the Canada-US boundary was by then settled, some fears remained about annexation. Nor were these completely unjustified; as recently as 1868 the state of Minnesota had offered $\$ 10$ million for Rupert's Land, and met the rejection of the offer with a resolution in favour of annexing the territory to the United States. ${ }^{27}$ The belief that there was gold in the Quetico area also clearly influenced the negotiators. In his report, Lieutenant-Governor Alexander Morris described the Treaty \#3 area as "a wide extent of fertile lands, and, as is believed, great mineral resources." 28 Newspaper reports on gold prospecting in the Shebandowan had appeared in the Globe and Mail in recent years; perhaps for that reason, this was the area in which the commissioners attempted to obtain carte blanche consent to the treaty before the negotiations. When the reserves were set out in 1874 , the Minister of the Interior ordered the commissioners to exclude any land likely to bear mineral resources. ${ }^{29}$

\footnotetext{
${ }^{26}$ Ibid.

${ }^{27}$ Dickason, 246.

${ }^{28}$ Morris, 46.

${ }^{29}$ Report of Privy Council to Ministry of the Interior July 8,1874
} 
Most importantly, the Canadian government wanted to ensure its access to the West, by road and subsequently by rail. Although the Dawson Road had been built, the federal government was aware that the Ojibway were not satisfied with the way that their loss of territory had been compensated. The Ojibway had received three dollars "per head"30 - with no explanation of who was included in this -on the first year the Dawson Road was opened, but had received nothing since, either for passage or the use of trees and waterways. ${ }^{31}$ Ojibway dissatisfaction with this arrangement was a potential security threat to settlers on the Dawson Road; the Ojibway had threatened to physically prevent access to areas in the past, and Morris asserted that in the absence of a treaty, "the Government would have been compelled to place a force on the line next year." ${ }^{32}$

The government perspective on the value of the Quetico area can be seen in Commissioner Dawson's description of Ke-ba-quin, the Sturgeon Lake band chief:

Chief of the region between the present line of the Red River route and the United States boundary line, east of Rainy Lake and west of the height of land. The gold bearing country is in this chief's district. ${ }^{33}$

From the Commission's perspective, the significance of the chief is related entirely to his control over territory, as opposed to his leadership of a community or his position within the Ojibway political system. Of the three Shebandowan chiefs, only Metas-so-que-neshauk of Lac des Mille Lacs merited a comment on his leadership: he was described as "a very intelligent man"34 because the Ojibway in his area had demonstrated some interest in agriculture, which was considered the first step on the path to assimilation. The value of the land itself is reduced to the three elements described above. Access to land and

\footnotetext{
${ }^{30}$ Morris, 49 .

${ }^{31}$ Ibid., 48.

${ }^{32} \mathrm{Ibid} ., 51$.

${ }^{33}$ Ibid., 328.

${ }^{34} \mathrm{Ibid}$.
} 
assimilation were the values underlying policy decisions, regardless of public expressions of concern regarding the needs of Aboriginal people. Once the treaty was signed, the Ojibway found that many of their concerns went unanswered by the Dominion government.

\section{"Simply moral and no more"}

In many instances, Aboriginal authority and needs have simply been ignored. Very soon after Treaty \#3 was signed, for example, the requirement of Aboriginal consent to any sale or lease of reserve lands was repealed, contradicting the terms of the treaty. By 1898 , the federal government shifted the power to unilaterally allot reserve lands and lease 'undeveloped' reserve lands from band councils to the SuperintendentGeneral of Indian Affairs, precisely because chiefs and bands across the country were resisting such initiatives. In addition, having served their purpose in obtaining treaty signatures, the federal government now banned Grand Councils. Through this denial of legitimacy, the federal government asserted a repressive political authority over the Ojibway, the legacy of which continues to frustrate the development of contemporary self-governance structures. ${ }^{35}$

Anthropologist Sally Weaver has argued that similar tactics have been used repeatedly to consolidate federal control over Aboriginal people. She suggests that what she terms "political representivity," ${ }^{36}$ the legitimacy that makes political authority possible, has been used by the government as a strategic resource to be awarded or

\footnotetext{
${ }^{35}$ For example, a 1998 Grand Council report states that the ban on Grand Councils interrupted the transmission of the skills and knowledge of governance, a loss contemporary leaders must now struggle to overcome (TARR, We Have One Mind, 50).

${ }^{36}$ Weaver, 114.
} 
withdrawn at will. This creates a situation in which the authority of Aboriginal political leaders becomes tied to federal recognition and approval, a status that is assigned rather than achieved. From the period of the treaties on, Aboriginal leaders have been caught in this dilemma. To be able to negotiate effectively for services and the recognition of their rights, they must maintain government approval. This often requires compromise and the abandonment of certain tactics. Chief Blackstone lost this approval when he attempted to circumvent the chain of government authority by traveling to Ottawa, a strategy the government deemed unacceptable.

At the same time, in order to maintain their authority within their communities, Aboriginal leaders must be seen to be consistent and emphatic in their struggles. In the Quetico, as elsewhere in Canada, provincial and federal governments have often chosen to ignore prominent leaders who oppose them in favour of minor leaders who agree. In the case of Treaty \#3, the three chiefs chosen as principal negotiators were pushed to the sidelines once Governor Morris obtained the support of one local chief from Lac Seul. Similarly today, an attack on the legitimacy of an Aboriginal leader's authority is often a key strategy of the federal government. ${ }^{37}$ In terms of frame theory, such refusals to acknowledge Ojibway social and political rules constitute the government's form of social sabotage, a direct challenge to the social framework. It is a continuation of a strategy of undermining Aboriginal governance structures that has been in place since the

\footnotetext{
37 Ibid., 117-118. This can most recently be seen in the federal response to the AFN's strong opposition to the introduction of the FNGA. INAC dismissed the AFN as "some First Nations leaders" as opposed to the "many First Nations people and leaders" they say supported the FNGA. (Canada, Indian and Northern Affairs Canada, "About First Nations Governance: FAQ's [report on-line]," accessed April 10, 2003; available from http://www.fng-gpn.gc.ca/QA1_e.html.
} 
nineteenth century. Olive Dickason has clearly stated that the first Indian Affairs laws passed after Confederation "were designed to break down tribal forms of government." ${ }^{\text {"38 }}$

Following the signing of Treaty \#3, the reserves were laid out, and the timber barons moved in. While the industry was generally moving west and north as the eastern forests became exhausted, in the case of the Quetico and the larger Treaty \#3 area the expansion was intensified by inter-governmental politics. While the treaty had been negotiated by the Dominion of Canada, the Ontario government had been quick to assess the value of the lands and to lay claim to them. Prime Minister John A. Macdonald refused to acknowledge Ontario's claim, not wishing to give up access to the resources the federal government had just gained through the treaty. Using Aboriginal title as the basis of his claim, he insisted that the lands had been legally conveyed from their original owners to the federal government. He declared angrily that the Northwest Angle had "not one stick of timber, one acre of land, or one lump of lead, iron or gold that does not belong to the Dominion." ${ }^{39}$ To demonstrate this, he began to give away timber limits to his political friends, literally dozens of them, ignoring critics in the House of Commons who denounced this as illegal. ${ }^{40}$ One of these controversial limits went to the St. Catharine's Milling and Lumber Company, and it was this business Ontario Premier Oliver Mowat chose to take to court on a charge of illegally logging Ontario Crown lands in 1885 .

The prominent MP D'Alton McCarthy, a man Macdonald hoped would be his successor as leader of the Conservative Party, agreed to act on behalf of the lumber company. McCarthy based his argument on the legitimacy of Aboriginal title, which

\footnotetext{
${ }^{38}$ Dickason, 239.

${ }^{39} \mathrm{John}$ A. Macdonald quoted in Dickason, 323.

${ }^{40}$ Cottam, 120 and 125 n. 12.
} 
made the treaty equivalent to a sale of land. According to senior INAC researcher S. Barry Cottam, this effectively forced the Ontario government to develop the opposite argument, that rather than being owners of the land the Indians had only a primitive right of occupancy. ${ }^{41}$ The fact that they owned land communally rather than privately was used against them, because it was assumed that this indicated a lower stage of cultural development and an inability to effectively exploit natural resources. Since the use of natural resources was, from the colonial and settler perspective, the primary purpose of land ownership, the Ojibway of Treaty \#3 could never be considered landowners. Mowat therefore claimed that "there is no Indian title in law or equity. The claim of the Indians is simply moral and no more. ${ }^{.12}$

Ontario won the case, and Treaty \#3 was declared invalid. Later that year, the Ontario Court of Appeal upheld the decision, as did the Supreme Court of Canada in 1887. Finally, in 1888, the case came before the Privy Council. Edward Blake, federal Liberal Party leader from 1880-87 and Ontario Premier from 1871-74, acted on behalf of the province. Blake repeated an argument that Mowat had made, which used English law to argue that the Crown had automatically gained ownership of the land upon discovery, since only the laws of Christian nations should be considered as valid. ${ }^{43}$ He argued that anything less than full ownership rights would require that the treaty negotiations result in the passing of the land not to the Dominion, but to Ontario, and he won. The number of major political figures of the period involved in this case is indicative of its significance, since it opened a new discussion of the balance of powers between

\footnotetext{
${ }^{41}$ Ibid., 121-122.

${ }^{42}$ Oliver Mowat quoted in Dickason, 324.

${ }^{43}$ Dickason, 324.
} 
Dominion and provinces laid out in the BNA Act. Under these circumstances, the rights of the Ojibway were seen only as a theory to be debated.

Not only did the final decision in the St. Catherine's Milling case create a new legal obstacle for Aboriginal people, Cottam argues that it also exacerbated the federalprovincial dispute over Aboriginal territory. In the case of Treaty \#3, this can be readily seen through an examination of a 1905 arbitration hearing in which the federal government sought compensation for the expenses of the treaty from Ontario, arguing that the latter had derived all the economic benefits of the treaty. Again, however, Ontario prevailed, arguing that the majority of the costs derived from the federal responsibility for Aboriginal people and that the remainder was the result of overly generous treaty negotiations. ${ }^{44}$ From the Ontario perspective, Aboriginal people were not owners and therefore were not entitled to ongoing payments. As wards of the state they could be considered as objects of charity, but this was construed as a choice made by the federal government, which should therefore bear the responsibility for its largesse.

Oliver Mowat, by now Attorney-General, again appeared in Ontario's defense. In his argument he introduced yet another strand to the debates, stating that "it appears that the said reserves have been selected with reference to their value as timber lands rather than as suited to agricultural development and their suitability for homesteads." This, he claimed was "without the term, spirit and intention of the treaty." His argument was that either the Indians themselves, or the agents of the federal government, were deliberately choosing reserve lands that could be sold as timber reserves in order to keep them out of Ontario's reach. There does not appear to be any evidence to support this suggestion,

\footnotetext{
${ }_{44}$ Ontario, "Indian Claims, North West Angle Treaty no. 3," in Sessional Papers Number 61, May 9, 1905, (Ottawa: Canadian Library Association, microfilm).
} 
however. Furthermore, he claimed that only agricultural and settlement lands were included in the treaty, which was inaccurate, since hunting and fishing territories were also considered valid reserve lands.

Whether or not the federal government wanted the timber reserves, Mowat certainly revealed provincial greed and his ignorance of Aboriginal culture. It seems to have totally eluded him that forested areas would be desirable as hunting territories, as opposed to previously-logged areas, swamps or open, rocky lands. His statement that the claim upon which the treaty was based was "simply moral and no more" seems to have been made to imply that it was no claim at all. Not only was his interpretation of Aboriginal land rights conservative even by the standards of the nineteenth century, but he demonstrated no knowledge of the federal concept of fiduciary responsibility. His interpretation of the federal role seems to have been limited to ensuring that the Dominion bore all the costs of treaty negotiation.

Ontario pursued its claim to the Northwest Angle with such persistence for a very good reason. In an era before direct taxation, the revenues derived from timber licensing were the single greatest direct income source for the Ontario government, a revenue generator exceeded only by the federal transfer. Between 1867 and 1899 forest revenues accounted for an average of $28 \%$ of the government revenues, and auctions of timber limits were regularly used as a means of generating extra income, especially before elections. ${ }^{45}$ The "simply moral" claims of Aboriginal people paled into insignificance in comparison with the revenues that could be derived from this massive area of forest.

${ }^{45}$ Nelles, 18. 


\section{"The Indians would not be interfered with"}

The entry of Ontario into the politics of the Quetico was nothing short of disastrous for the Ojibway. Mowat denied their rights to the Treaty \#3 lands and challenged even the tiny percentage of the area held as reserves. Furthermore, it was an Ontario civil servant, Aubrey White, who denied the Sturgeon Lake band its 1896 transfer request and demanded the abolition of the reserve in 1913, as well as the surrenders of five Rainy River reserves. With more than an echo of Mowat's easy dismissal of Aboriginal rights, it was also White who assured Indian Affairs in 1909 that "the Indians would not be interfered with" ${ }^{46}$ in the Quetico Forest Reserve.

In fact, Ontario officials were responsible for the forcible removals of Ojibway from the park, including families, often at gunpoint. ${ }^{47}$ In 1905 the Provincial Treasurer condemned the Ojibway as "an incubus upon the territory." ${ }^{48}$ Ontario Game Inspectors disabled Ojibway traps and confiscated their fishing nets, beginning at least as early as 1909 and continuing for at least twenty years. ${ }^{49}$ At the same time, the inspectors acknowledged that rail and logging employees continued to kill game for food within the reserve area, and yet they were not prosecuted. ${ }^{50}$ Since there were only ten rangers, working in pairs and traveling on foot through the 4,700 square kilometre reserve, it was not difficult to avoid them. ${ }^{51}$ While the rangers would likely have known the regular

\footnotetext{
${ }^{46}$ Aubrey White quoted in Killan, 23.

${ }^{47}$ Leo G. Waisberg, Joan A. Lovisek and Tim E. Holzkamm, "'An Incubus'", 347.

${ }^{48}$ Ibid., 339.

${ }^{49}$ Treaty and Aboriginal Rights Research, "We Have Kept Our Part of the Treaty": The Anishinaabe Understanding of Treaty \#3 [report on-line], (1998), accessed June 4, 2002; available from www.landclaimsdocs.com/conferences/Quebecpdf/GrandCouncilTreatyNo.3final.pdf, 8. ${ }^{50} \mathrm{Killan}, 22$.

${ }^{51}$ Ibid.
} 
camp locations of both Ojibway and white hunters, however, it seems clear that they focused their efforts only on harassing the Ojibway.

After its 1905 court victory, Ontario no longer felt constrained by claims to the Quetico from either the Ojibway or the federal government. The federal government, defeated in the courts, began to make policy changes to facilitate provincial expansion. In 1911, Minister of the Interior Frank Oliver introduced an amendment to the Indian Act to allow for the expropriation of reserve lands for public works. To ensure its passage through the House, Oliver framed Aboriginal people and their reservations as obstacles to a potent symbol of modern industrial society, the railways. The minister claimed that, "the whim of a band would no longer obstruct a provincially-chartered railroad company from developing a certain part of the country." ${ }^{52}$ In practice, however, in the Quetico the new law was used to compel the six Rainy River bands to amalgamate onto a single reserve for the benefit, not of the railway, but of the timber barons.

In a 1929 memorandum, the Supervisor of Indian Timber Lands noted that "many instances of absolute persecution of Indians on the part of officious game wardens have been reported" and that "due entirely to the action of the province of Ontario in curtailing their hunting and fishing rights" he believed that "the Indians of the Treaty N.3 area (Lake of the Woods) are possibly facing today the worst conditions of living that they have ever experienced. ${ }^{153}$ He went on to ask the Deputy Minister of Indian Affairs for a test case to contest the power of the province to violate treaty promises, a request that was presumably rejected, since no such case was ever drawn up. Correspondence on Sturgeon Lake continued through 1929 and 1930, most of which focused on efforts to

\footnotetext{
${ }^{52}$ Frank Oliver quoted in Gibbons, 27.

${ }^{53}$ H. J. Bury to the Deputy Minister September 17, 1929, TLS, NAC RG10 Vol. 7537 File 124-9, 30.
} 
transfer the band membership of individual Sturgeon Lake Band members to the Lac des Mille Lacs and Lac La Croix bands. The possibility of an alternate reserve was raised by Chief Surveyor David Robertson, but was rejected, presumably due to the fact that, as he noted, Ontario would not likely grant such a request and the federal government would then be required to purchase land for the band. ${ }^{54}$

\section{Federal inaction}

The federal government was negligent in its treaty responsibilities on multiple fronts. When Ontario offered to confirm all the Treaty \#3 reservations on the condition that Canada drop its suit for administrative costs, the federal government rejected the compromise. Canada lost its case in 1905 , and then in the 1913 negotiations it gave up the reservations as well. Although the province was advised, prior to the 1913 negotiations that canceled the Sturgeon Lake reserve, that "no disposition can be made of these Reserves [Sturgeon Lake and Lac La Croix] without a surrender from the Indians, ${ }^{155}$ neither Ontario nor Canada attempted to secure such permission. The federal government made little effort to curtail the activities of Ontario officials, even when it was made aware of them. In its enthusiasm for assimilation, Indian Affairs was quick to declare the Ojibway of Sturgeon Lake extinct and slow to acknowledge the continued existence of treaty rights to hunt, fish and trap in the Quetico.

Well before the official elimination of the reserve, Indian Commissioner David Laird wrote confidently in 1902 that the Ojibway "never live on" the Sturgeon Lake

${ }^{54}$ Donald Robertson to JD McLean August 16, 1928, TLS, NAC RG10 Vol. 7537 File 124-9, 18.

${ }^{55}$ Assistant Deputy and Secretary of Indian Affairs to TW Gibson, Deputy Minister of Mines, Ontario "in reply to your letter of the $23^{\text {rd }}$ \{April 1913]", TLS, NAC RG10 Vol. 7537 File 124-9, 20. 
reserve, and that there were "only about twenty Indians in this Band," despite the fact that he admitted that "the Agent sees them only at the annuity payments, ${ }^{56}$ a fact borne out by the agents' records throughout the history of the reserve. His estimate of the numbers of Sturgeon Lake Ojibway raises the question: where did everybody go? The reserve was laid out at 5762 acres, or 9 square miles. According to the terms of the treaty, this would mean that it was intended to serve a community of approximately 45 people, since the treaty allowed one square mile for each family of five or the equivalent. ${ }^{57}$ The estimate that the band had only "about twenty Indians" would mean that over half of the Sturgeon Lake band had disappeared in thirty years. There are no records of epidemics in the region in this period, nor do the agents' records suggest an unusually high death rate at Sturgeon Lake. ${ }^{58}$ The estimate of twenty band members in 1902 , based on a report by an agent who visited only once a year, should therefore be seen as highly suspect.

The Deputy Superintendent General of Indian Affairs, Duncan Campbell Scott, was strongly in favour of rapid assimilation, and viewed traditional land uses as an impediment to be removed, rather than as a right to be protected. He did not use his considerable influence in the Indian Department to protect treaty rights, but rather to encourage compliance with Ontario. This was seen most dramatically in the 1913 negotiations that led to the elimination of the Sturgeon Lake reserve.

It seems unlikely that Indian Affairs attempted to explain the creation of the forest reserve to the Ojibway before the fact. In an internal memorandum dated August $1^{\text {st }}$, 1928 , the question was asked, "Is there anything to show that the Indians were advised as

${ }^{56}$ David Laird to Secretary of Indian Affairs January 23, 1902, TLS, NAC RG10 Vol. 7537 File 124-9, 14.

${ }^{57}$ Northwest Angle Treaty, Number Three reprinted in Morris, 322

${ }^{58}$ Although there is a note of "protracted sickness" in an 1894 report, the statistical information indicates that there was only one death, offset by two births. T.C. Comish to Inspector of Indian Agencies Sept 9, 1894, ALS, "Outgoing Correspondence", NAC RG 10 C-V-23. 
to this [the elimination of the reserve] or any attempt made to get the Indians a Reserve in lieu?" Notes added to the side of the memo, possibly by senior civil servant J.D. McLean, to whom it was forwarded, read simply "no record." 59 In the fiery protest letter he wrote in 1910, the trader Leo Chosa stated that to his knowledge, the only notice any Ojibway had received of the creation of the forest reserve was through English-only written notices nailed to trees.

\section{A "really exclusive marketable commodity"}

Despite this extensive collusion between provincial and federal officials, there proved to be further obstacles to the economic development of the Quetico. Just as Ontario began to sell timber limits and construct roads in the Quetico in the early 1900's, a new group arose to lay claim to the land. Wilderness enthusiasts, people who enjoyed canoeing, fishing and camping, began to campaign for lands to be set aside as park areas, safe from industrial development and especially from settlement. After only four years as a forest reserve, the Quetico was transformed into a provincial park in 1913, and from that point on the white public became increasingly interested in its uses. The most prominent leader of the early conservation movement was Ernest Oberholtzer, "a selftaught naturalist, expert on Ojibway culture, and an island resident on Rainy Lake since 1912." ${ }^{160}$ He developed a plan in 1927 to protect the Quetico-Superior area, including the whole Rainy Lake watershed, from roads, dams and logging activity. While the railway publicist Arthur Hawkes sought to create an image of the Quetico as steeped in the history of the fur trade, Oberholtzer envisioned a central wilderness area "kept as nearly 59"Internal Memorandum," August 1, 1928, forwarded to J.D. McLean, TD, NAC RG10 Vol. 7537 File 124-9, 24.

${ }^{60}$ Warecki, 20. 
as possible in a state of nature with no roads and no sign of human activities [along visible shores on the canoe routes] except such as may pertain to the present normal life of native Indians." ${ }^{61}$ Despite Oberholtzer's expertise on the Ojibway, he seems to have been unaware of the threats the park would pose to this "normal life." Oberholtzer was opposed by the timber industry, especially the local MLA and timber baron Jim Mathieu, who had obtained cutting rights in the Quetico under dubious circumstances.

While at first the numbers of conservationists were small, they rapidly drew in some very high-profile supporters. Clifford Sifton, Vincent Massey, and the owners of major businesses such as Abitibi Pulp and Paper and Massey-Harris formed the Canadian Quetico-Superior Committee in 1949, armed with a letter of support from US President Eisenhower. The Oberholtzer plan failed, however, primarily because the QueticoSuperior Committee hoped to develop the Quetico into an international park, joined with the Superior National Forest across the border in Michigan. Ontario refused to contemplate anything that might imply federal rather than provincial jurisdiction over the park. $^{62}$ The presence of prominent federal political figures such as Sifton and Massey would only have exacerbated these fears.

The efforts of Oberholtzer were hardly fruitless, however. In 1930, the Quetico Park Superintendent ordered the modification or complete withdrawal of timber rights on eight popular canoe routes, following Oberholtzer's goal of maintaining the image of a pristine wilderness. Furthermore, in 1960 a Joint Advisory Committee was established with Minnesota to negotiate and administer trans-boundary issues such as water quality.

\footnotetext{
${ }^{61}$ Ernest Oberholtzer quoted in Warecki, 21.

${ }^{62}$ Killan, 93.
} 
In order to maintain its hold on the land, the Ontario government gradually developed a new vocabulary of protection and stewardship. While the creation of forest reserves had been based on appeals to efficiency and the orderly exploitation and renewal of forest resources, parks in the 1920 's and 30 's were portrayed as havens of recreation and escape from urban life. The value of wilderness was now seen to lie in its isolation from everyday life, as well as in its natural resources. In the 1950's, conservationists compelled the Ontario government to add a third value to this list, that of ecological integrity. In response to the criticisms of the Federation of Ontario Naturalists and other conservation groups, the Ontario government passed the Wilderness Areas Act in 1959. As the Minister of Lands and Forests made clear in 1956, however, ecology was less of a concern than profit. He explained that the provincial government must continue to preserve "the hinterland, " because "wilderness is one of our really exclusive marketable commodities." 63

In the Quetico, the new values of wilderness became apparent in several ways. Hunter's Island was set aside from logging activities as a recreational park area in 1943, although all logging in the park ceased in 1946 due to the depletion of the forest. The Thunder Bay-Atikokan highway opened in 1954, running along the northern border of the park, slightly reducing the total park area but increasing tourist access. The Ontario government began to fund the publication of books about the Aboriginal history of parks, including Emerson Coatsworth's The Indians of the Quetico in 1957 and Dewdney and Kidd's Indian Rock Paintings of the Great Lakes in 1962. The province also sponsored the development of a complete naturalist program in the early 1960's, recognizing an

\footnotetext{
${ }^{63}$ Minister of Lands and Forests CE Mapledoram, quoted in Ontario, Ministry of Natural Resources, "Objectives for Park Use" in Quetico Provincial Park Master Plan (Toronto:Ministry of Natural Resources, 1977).
} 
increasing public appetite for an educational component in park development. ${ }^{64}$ Suddenly, the Ojibway had a marketable value to the Ontario government, although it would be decades before they themselves had any control over publicity materials generated to promote the park.

Ontario therefore largely controlled public perception of the Ojibway. Emerson Coatsworth, author of The Indians of the Quetico, began by acknowledging the 1873 treaty, presumably to establish the validity of the land transfer. He then abandoned the historical Ojibway in favour of romanticized descriptions of "these Ojibwa of the seventeenth century." ${ }^{65}$ He described "the few hundred"66 Ojibway of the Quetico as "an artistically inclined people" ${ }^{67}$ who suffered through "a difficult life at best, [since] the threat of starvation haunted Ojibwa families from birth to death." ${ }^{68}$ This book was published by the Quetico Foundation, a conservation group officially supported by the Ontario government beginning in 1956 and continuing to the present day. Coatsworth's fictional portrayal completely ignored the living population at Lac La Croix on the southern edge of the park, who not only acted as guides but also held licensed traplines in the park area. Although regular park users might therefore have been aware of the contemporary Ojibway, they were erased from this and other publications. In their place, fictional Indians were portrayed as the starving artists of the ancient wilderness, long extinct and politically irrelevant. As Arthur Hawkes had proposed thirty years earlier, it was the fur trade that constituted the "history" of Quetico Provincial Park.

\footnotetext{
${ }^{64} \mathrm{Killan}, 124$.

${ }^{65}$ Coatsworth, 3 .

${ }^{66}$ Ibid., 5.

${ }^{67}$ Ibid., 39.

${ }^{68}$ Ibid., 43.
} 


\section{Federal initiatives in the Quetico 1948-1970}

Ironically, the Ojibway traplines that were the contemporary remains of the fur trade were constrained by regulation and suppressed in park literature. The federal trapline registration system, introduced in the Quetico in 1948, formed part of another government strategy of land control. In Maps and Dreams, a study of the mapping process that accompanied the Mackenzie Valley Pipeline Inquiry in the 1970's, Hugh Brody described the registered lines as "an attempt to introduce an orderly White presence into the wilderness, ${ }^{169}$ controlling Aboriginal land use and developing the concept of individual ownership. Furthermore, he argued that "the attempt to extend the registration of traplines to Indian people constituted a violation of Indian rights; its explanation to Indians amounted to an outright lie.."70 Brody argued that subsequent to registration, traplines have been used as symbols of the extent of Aboriginal hunting and trapping territories: as a result, in the minds of government officials Aboriginal subsistence rights have been reduced to the strips of land along which the traplines run. Supporting this argument, in the Quetico park negotiations of the 1970's it was apparent that traplines and reserves were the only parts of the land considered to be eligible for Aboriginal use, in stark contrast to the original terms of the treaty, which emphasized Ojibway access to all their hunting and fishing territories.

In the 1960 's, the Indian Affairs department began to focus closely on the question of economic self-sufficiency on reserves. Since the Indian Act severely restricted the potential for economic development on reserves, new programs were

\footnotetext{
${ }^{69}$ Hugh Brody, Maps and Dreams: Indians and the British Columbia, (Vancouver: Douglas \& McIntyre, $1988), 88$.

${ }^{70}$ Ibid., 94.
} 
developed especially for reserve communities. In 1964, the Amik Association was created to promote local economic development. Federally-funded, Amik employed local people to encourage small-scale entrepreneurship. In 1970, it assisted several Treaty \#3 reserves to obtain timber licenses and to negotiate pulp contracts with Boise Cascade. This represented a significant potential economic benefit to the reserves, because while Ojibway people had been hired as loggers for decades, they had been unable to compete against larger companies for their own cutting rights. 125 Ojibway were employed through the Amik timber project in 1970, in jobs that were subsequently eliminated with the provincial logging ban in 1971. Amik also proposed to support the development of a commercial coarse fish harvest to support mink ranching in the area, which would have offered employment for Ojibway in both fishing and ranching. In its brief to the Advisory Committee in 1971, Amik recommended that resource extraction rights within Quetico Provincial Park should be limited to "the exclusive economic development of the Indian people in the Rainy River district. ${ }^{.71}$

\section{"Buried under English words"}

As discussed in Chapter Three, the Ojibway fought hard to retain their limited access to the park for trapping and fishing purposes. Although they lost on the timber issue, in other areas the Ojibway did manage to retain some user rights. For example, while trapping and the use of motor boats were prohibited for the general public in the 1977 Master Plan for Quetico Provincial Park, an exception was made for the Lac La Croix community. The rationale for this exception was euphemistically characterized in

\footnotetext{
${ }^{71}$ Amik Association, "Brief" in Public Hearings by and Briefs to the Quetico Provincial Park Advisory Committee, 4 vols, ( By S.G. Hancock, Chairman, 1972), Volume 2.
} 
the report as "the immediate effect [the ban on outboard motors] would have on local situations." ${ }^{72}$ Similarly, a recommendation for the preferential hiring of local Ojibway guides was described as "phas[ing] out non-resident guides. ${ }^{\text {"73 }}$ In the list of 26 recommendations, there is only one direct reference to "native people," in a reference to their traplines. The impression left on the reader is that the provincial government did not wish to be seen to be catering to the interests of the Ojibway.

Indeed, it is obvious throughout the master plan that the needs of the Ojibway continued to be peripheral concerns at best. Although the people of Lac La Croix asked for road access to their reserve, the request was denied because roads in the Quetico were intended only "to facilitate visitor entry to the park, ${ }^{174}$ and were restricted "in order to retain the 'wilderness' environment for visitors." ${ }^{.75}$

The romantic image of the Ojibway continued to be used to promote the park, which was described as "one of the few parts of North America which remains almost as it was before the coming of the white man ... originally peopled by Ojibway Indians living mainly by hunting, fishing and trapping." ${ }^{76}$ This effectively obscured the continuing presence of the Ojibway in the Quetico. In this and countless other descriptions of the park, the interest value of the land was framed in terms of its association with the history of exploration. Its value lay in the opportunity it provided for the modern visitor to see Canada "as it was," through the eyes of the explorers. Further on, the Master Plan proclaimed that "here, preserved like a gilded fly in amber, is the

\footnotetext{
72 "Recommendations" in Ontario, Quetico Master Plan.

${ }^{73}$ Ibid.

${ }^{74}$ Ontario, Quetico Master Plan.

75"Uses of Park Resources 4.7: Access to Park" in Ontario, Quetico Master Plan.

${ }^{76}$ "Historical Background" in Ontario, Quetico Master Plan.
} 
Canadian wilderness as the explorers and fur traders knew it centuries ago." ${ }^{17}$ Given such a romantic image, associating the Quetico with a history of visionary and powerful white men, it was easy to suggest a role for the Ojibway as helpers, "who showed the trader how to adapt to the environment." ${ }^{78}$

One of the most popular canoe routes through the Quetico has always been the traditional Ojibway route leading from Lac des Mille Lacs north of the park, through Sturgeon Lake and down to Lac La Croix, three communities represented in Treaty \#3. Although the Master Plan acknowledged that this was an Ojibway route with an Ojibway name, Kaministiquia, it has been dubbed the "Dawson Route," as if Simon Dawson and his Red River Expedition discovered it for the first time. These are examples of the common phenomenon described by the Native American author Leslie Marmon Silko, in which "all the names ... were buried under English words. ${ }^{779}$ On a metaphorical level, the erasure of Aboriginal place names represents the legacy of the assimilationist program to bury all aspects of Aboriginal cultures beneath the edifice of a colonial Canada.

Indeed, the Ontario government's narrative continued to ignore the existence of Treaty \#3, which was not mentioned in the official history. Instead, the story moved rapidly from the journey of French explorer Jacques de Noyon in 1688 to the beginning of commercial logging in the 1880 's. Of the Ojibway in this period, the Plan suggested that

This ancient and lengthy period of comparative quiescence in this wide area, when small bands of natives roamed the woods, was succeeded near the dawn of the present century by one of great activity. ${ }^{80}$

\footnotetext{
${ }^{77}$ Ibid.

${ }^{78}$ Ibid.

${ }^{79}$ Quoted in Henderson, 253.

80"Historical Background" in Ontario, Quetico Master Plan.
} 
The Dawson expedition of 1857 was noted briefly and then abandoned. Of the period of logging and mining, the history suggested that despite some industrial activity, "the Wilderness was left intact." ${ }^{11}$ The authors rapidly move on to the creation of the forest reserve and the park, abandoning the history of the Ojibway who "roamed the woods," presumably undisturbed. Needless to say, the elimination of the Sturgeon Lake reserve was not mentioned, since this would certainly have contradicted the image of provincial goodwill the Committee now attempted to establish.

This history paved the way for a new image of the provincial relationship with the Ojibway by simply suppressing all mention of conflict or even negotiation. Silence on the matter of the treaty effectively eliminated any suggestion of Aboriginal land rights. The only faint suggestion of Ojibway land rights in the Quetico was an acknowledgment of the registered traplines. ${ }^{82}$ The Ojibway commercial fishing enterprises of the 1960 's were referred to only as being "on Lac La Croix." ${ }^{83}$ Again, the Ojibway were not named. Instead of acknowledging Ojibway land rights, the suggestion was made that just as the Ojibway helped the early explorers, so had the government offered its hand to assist the Ojibway, in a spirit of fairness and even generosity. The plan made the following extraordinary statement on the provincial relationship with the Ojibway:

The economic impact of the Park's commercial activities is important to people living in the area, and especially the Indians. This has obviously been considered fully in the past [emphasis mine]. ${ }^{84}$

The summary of the meeting the Advisory Committee held with the Lac La Croix band in 1971 ended on a similarly cheerful note:

\footnotetext{
81 "Ibid.

${ }^{82}$ Since these are under federal jurisdiction, they could not have been withdrawn without federal consent.

${ }^{83}$ "Uses of Park Resources Section 4.3: Angling "in Ontario, Quetico Master Plan.

84"Uses of Park Resources 4.9: Summary on Uses" in Ontario, Quetico Master Plan.
} 
Questioned concerning the future, it appeared that most members of the Band were satisfied with their lot, they felt the village had been their home for generations, and they intended to stay there. ${ }^{85}$

It is true that the Plan recommended that Lac La Croix guides be given exclusive rights to use small outboard motors along some routes. The Ministry of Natural Resources still stated that its goal was the ultimate elimination of all motorboats in the park, however. The Lac La Croix Band also asked for a sawmill for their own use, which does not appear to have been constructed, and for road access, which was only established in 1996 with funding provided at the time of the 1991 official apology. Moreover, the phrase "satisfied with their lot" does not correspond with the public statements made in the hearings and discussed in Chapter Three. The people who spoke and signed their names to the brief did not portray themselves as satisfied, but rather as "speaking from the point of view of the poor and unprivileged." 86

\section{The 1991 Ontario Apology}

Quetico Provincial Park policy has continued to allow some exceptions for the Lac La Croix Ojibway on the issues of motorboats and traplines. Throughout the 1980's, the Ontario government continued to frame its relationship with the Ojibway in terms of a "moral claim," rather than an issue of rights, but in 1991, under the New Democratic government led by Premier Bob Rae, Ontario made an official apology to the Lac La Croix First Nation. Native Affairs Minister Bud Wildman acknowledged for the first time that the province had played a role in the historic and contemporary abuse of

\footnotetext{
85" Objectives for Park Use 6.8:Lac La Croix Band" in Ontario, Quetico Master Plan.

${ }^{86}$ Public Hearings, Volume 2: Toronto Hearings, p. 82
} 
aboriginal rights in the Quetico. Although he was careful to point to the lack of responsible action on the part of the federal government, he stated clearly that:

[O]ur government is prepared to make a public apology to the Lac La Croix first nation for the lack of respect that has been shown to its people and to its rights. ${ }^{87}$

He located the primary source of blame in the lack of consultation with the Ojibway in 1913. While this undoubtedly played a role, Ontario had also been aggressive in its refusal to consider even the moderate measures of protection suggested by the federal government both before and after the creation of Quetico Provincial Park. Wildman then went on to propose several measures of compensation, including increased motorboat access within the park, money for the purchase of canoes and motors, and most importantly, a commitment of $\$ 500000$ to build a road into the community. He also stated that the province would support the Ojibway in their pursuit of a land claim for the loss of reserve 24C. This land claim, launched in 1980, asked for compensation for the loss of the Sturgeon Lake reserve and the resulting hardships. It has never been settled, and the file is now closed.

\section{Negotiating Self-Governance}

By the 1990's, the federal government had developed a policy of negotiating selfgovernment agreements with First Nations, and the Treaty \#3 Grand Council entered into this process in 1996. As discussed in Chapter Three the Grand Council has since been developing Bimiiwinitisowin Omaa Akiing, a model for Ojibway governance throughout the Treaty \#3 area. The federal government participated in the process of negotiating an

\footnotetext{
${ }^{87}$ Hon Mr Wildman "Lac La Croix Band" in Ontario, Legislative Assembly, Debates, 35th Parliament, 1 st session, June $3^{\text {rd }} 1999$.
} 
agreement on this model for six years, appointing a federal negotiator and meeting to discuss various aspects of the proposal. At the same time, however, INAC was in the process of developing the FNGA. Although this is a national issue, it has a particular significance for the people of the Treaty \#3 area because of their own governance proposal. After negotiating, apparently in good faith, for over six years, the federal government decided in November 2002 that each of the 28 band councils in Treaty \#3 must pass a resolution permitting the Grand Council to negotiate on their behalf. Preferring to use their own process of decision-making, the Grand Council presented Minister Nault with a letter of support signed by 25 of the band councils. Rejecting this as inadequate, Nault canceled the discussions. ${ }^{88}$

This is not an isolated phenomenon, but rather forms part of a federal government strategy to recognize only individual band councils and not grand councils. The FNGA emphasizes the role of elected band councils, while ignoring grand councils. Framing the bands as primary political bodies and suppressing the role of grand councils is strategically useful because grand councils offer much greater political power to Aboriginal people, many of whom come from small and isolated bands. Despite the fact that most treaties, such as Treaty \#3, were negotiated at the grand council level, they are not recognized as political entities by the INAC, but are treated as service delivery agencies, administered through regional offices. Recent policy changes mean that the work plans of grand councils will now have to be approved by INAC before funding is transferred, with the effect that each individual program of the grand councils will require separate approval. In addition, although the FNGA states that it will not affect treaty

\footnotetext{
${ }^{88}$ Christian Peacemaker Teams, Asubpeeschoseewagong Delegation Report November 2002 [report online], accessed May 21, 2003; available from http://www.prairienet.org/cpt/can_asub.php; Internet.
} 
rights or self-government negotiations, it was only a few months after its introduction that Minister Nault cut off negotiations with the Grand Council.

The speeches and press releases surrounding the introduction of the FNGA highlighted the consultation process, the outdated nature of the Indian Act, and the idea that the FNGA will offer increased independence for Aboriginal communities. INAC suggested that the proposed act will "help tear down the barriers to economic development" and "provide First Nations ... with the tools they need to foster effective, responsible and accountable governance." ${ }^{89}$ Without acknowledging the role that INAC and the Indian Act have played in removing the capacity for economic independence and the capacity for effective governance, the FNGA has been framed in terms of values of accountability, independence, and democracy.

In its promotion of the FNGA, INAC has framed its responsibilities in terms of values, stating that, "representative democracy, including regular elections by secret ballot, and transparency and accountability are broadly held Canadian values." ${ }^{\text {}}$ The implication that Aboriginal people are bound to the use of the ballot box by virtue of their relationship with the rest of Canada is a direct continuation of the colonial policy of opposing traditional leadership selection methods. ${ }^{91}$ Relating secret ballot elections to honesty and fair play, or 'transparency' and 'accountability', INAC implied that Aboriginal chiefs and councils may lack these qualities.

Governmental strategies continue to revolve around the amplification of values and the suppression of contradictory beliefs. The federal government has employed both

\footnotetext{
${ }^{89} \mathrm{Canada}$, Indian and Northern Affairs Canada, "About First Nations Governance: FAQ's [report online]," accessed April 10, 2003; available from http://www.fng-gpn.gc.ca/QA1_e.html.

${ }^{90}$ Canada, Bill C-7: First Nations Governance Act, $2^{\text {nd }}$ Session, $37^{\text {th }}$ Parliament, HC Canada, accessed May $26^{\text {th }}, 2003$; available from http://www.fng-gpn.gc.ca/FNGA_act_e.html.

${ }^{91}$ Dickason, 239 and 264.
} 
amplification and suppression, balancing appeals to efficiency and honesty against the suppression of inequality and deception, while the Ontario government has historically emphasized suppression alone. This forceful approach, which completely denied the existence of aboriginal rights, needs or concerns until the 1970 's, eliminated the need for the amplification of any values or beliefs to counter Aboriginal voices. With the resurgence of Aboriginal politics in the 1960 's and 70 's, however, it was no longer possible to entirely silence Ojibway leaders. Since that time, Ontario has moved to a presentation of itself as a friendly figure, framing the federal government as the source of blame. Suppression of the historical relationship between Ontario and the Ojibway has been necessary to the success of this approach. Overall, therefore, government strategies can be said to be dominated by the suppression of dissenting voices and stories, and secondarily by the amplification of the values of honesty, efficiency and fair play, legacies of nineteenth century British colonial values. Thus the desire to create "an orderly White presence" in the wilderness has taken precedence over the recognition of Aboriginal rights and needs.

The colonial discourse has been complicated by the division of powers between the federal and provincial government, but the desire for order and control has predominated at both levels. In the park itself, governance has sometimes been confirmed through the use of violence, as in the case of the removals of Sturgeon Lake band members from the park in the early twentieth century. More often, however, state control has been consolidated through language and symbolism. Government authority has been established through the inscription of an official history that relegates the 
Ojibway to a minor role, through the denial of Ojibway land rights, and through the refusal to accept the authority of confrontational Ojibway leaders. 


\section{CHAPTER FIVE CONCLUSIONS}

The history of political relations in the Quetico reveals that while Ojibway leaders have had minimal resources and political power, they have nevertheless been able to establish political leverage at several key points to retain some access to their traditional land. The complicating factor of the federal-provincial relationship had a severe, debilitating impact on the Ojibway, seen most clearly in the loss of the Sturgeon Lake Reserve in 1913. The relationship between language and power in this colonial discourse has been complex: while both the federal and provincial governments have used language as a means of establishing ideological control over the Quetico, it has also been an important site of resistance.

There is some evidence that state hegemony is indeed fragile and contested, as Gramsci suggested. This is seen not only in the occasional dramatic change of government policy, such as the 1991 Ontario apology, but throughout the many periods of negotiation over land rights and governance. Neither the federal nor the provincial governments have been able to sustain a total denial of Ojibway rights. Order requires consent, either willing or reluctant. Successive governments have found that they have needed to negotiate with the Ojibway to maintain their authority over the region. At the same time, state control has been in place for 130 years now, with no immediate end in sight. Resistance has been difficult and only partially successful. 


\section{Sites of resistance}

The history of the Quetico includes many examples of Ojibway resistance to the colonial discourse. Some of these have taken a formal, collective form, such as the treaty negotiations. In this situation, chiefs made overtly political statements of concerns arising from a structured series of local and grand council meetings. They tried first to re-define the frame of the discussions, an effort that began in 1870 with the meetings reported by Simon Dawson, in which the chiefs clarified that they wanted the discussions to be limited to the construction and use of the Dawson Road. In 1871 and 1872 they refused to negotiate on any other terms. Although Treaty \#3 was negotiated and signed in 1873 , its terms may reflect the partial success of this resistance.

In many other cases, there have been examples of the "everyday forms" of resistance as discussed by James R. Scott in Weapons of the Weak. While there was undoubtedly an element of self-interest in these forms of resistance, they are nonetheless political tools opposing the colonial occupation of land. For example, the Ojibway of Sturgeon Lake resisted the imposition of colonial authority when they refused to leave their land. Between 1910 and 1930, Ontario officials forcibly removed many Ojibway from the Quetico. This history of physical resistance is echoed in the current Grassy Narrows road blockades, which are taking a more formal political form with the support they are receiving from the Treaty \#3 Grand Council and Grand Chief Leon Jourdain.

As discussed in Chapter One, if state power is fragile, then it requires constant reinforcement, which takes the form of both governance practices and symbolic assertions of authority. I suggest that successful resistance movements understand the importance of symbolism as well as the practice of governance, and that one of their 
objectives is to expose and denaturalize symbols of state authority. To create a link between practices of governance and symbolic authority is to demonstrate that the state is a construction rather than a natural phenomenon, and therefore fragile and negotiable. Denaturalizing state authority undermines hegemony by expanding the range of what is considered possible. If resistance leaders are successful in accomplishing this, their capacity to negotiate is radically enhanced.

In the Quetico, evidence of resistance can be found in challenges to governance and authority on many levels. First, the continuing assertion of Ojibway land rights calls into question the legitimacy of the state's territorial sovereignty. Evidence of the use of state-sanctioned violence has been used strategically to call into question the legitimacy of state authority, as evident most tellingly in the 1991 Ontario apology and the response from Chief Steve Jourdain. Both Minister Wildman and Chief Jourdain emphasized repressive state actions, although the Minister was careful not to mention that provincial officials were responsible. Other examples include the ongoing resistance of Ojibway people to government efforts to control their economy, and their insistence that they have the capacity for autonomy. Finally, some Ojibway leaders have directly confronted colonial authority. In 1872, Chief Blackstone questioned the commissioners' power and ability to make decisions and threatened to go directly to Ottawa to negotiate the treaty. Last year, Grand Chief Leon Jourdain stated that he would bypass Minister Nault by waiting to re-open self-governance negotiations with his successor.

On the symbolic level, the Ojibway have resisted absorption into a national history through the public telling of their own history and experience of the land and their relationship with government, as well as through actions such as their recent request to 
have images of pictographs removed from publications about the park. There has been resistance to the imposition of a colonial history on the Quetico, as seen during the 1971 park hearings when Willy Wilson directly confronted the settler idea of wilderness as pristine and unpeopled. The resurgence of cultural confidence, as seen in the introduction of Ojibway words and references to Ojibway traditions and spirituality in the self-governance negotiations, constitutes another strategy of resistance to symbols of colonial authority, aimed directly at the policy of assimilation.

\section{Ojibway leadership and direct confrontation}

Anthropological studies of Ojibway politics have emphasized the use of "indirect communication" and avoiding the appearance of direct confrontation or competition. These practices appear to have been in evidence in the Quetico during several periods of negotiation, such as the treaty negotiations and the park hearings. At other times, leaders have been very direct in their questioning of colonial authority, as discussed above. Chiefs such as Blackstone, Steve Jourdain and Grand Chief Leon Jourdain have openly expressed their anger and frustration with government. This suggests that Ojibway negotiating strategies are multi-faceted and responsive, rather than strictly regulated by a single ideal of leadership.

Noel Dyck suggested that in general Canadian Aboriginal leaders have adopted more overt and confrontational tactics of resistance in recent years, in particular what he calls "the politics of embarrassment."1 In the Quetico this can be seen in the recent protests against the FNGA, which appear to be a departure from earlier tactics of

\footnotetext{
Dyck, 117.
} 
negotiation. In his use of sarcasm and irony, the presentation of Willy Wilson in 1971 has much in keeping with both the dramatic mockery of Governor Simpson in 1872 and the recent press releases from the Grand Council office. This continuity suggests that the use of humour as a tool to undermine authority is an important Ojibway strategy. Irony and sarcasm are examples of frame transformation, in that they change or reverse the intended meaning of a phrase or image. When Willy Wilson spoke sarcastically of the settler need for spiritual retreat and contrasted it with the Ojibway need for subsistence fishing and trapping, he transformed the intended concept of a wilderness sanctuary into a playground for the wealthy. This strategy appeals to an 'insider' Ojibway culture, but can also be understood by outsiders. It subtly denaturalizes the colonial discourse by undermining the idea of settler superiority.

\section{Expressing the Value of Ojibway Culture}

Resistance to a symbolic language of authority that suppresses the existence of Ojibway culture and experience has been a significant element in Ojibway strategy in the Quetico. For example, the introduction of untranslated words into governance negotiations represents an appeal to cultural distinctiveness and the importance of cultural survival. This is also seen in the re-introduction of language about "the Creator's law" and the Quetico as "a sacred land"2 after a century of silence on such issues following the signing of the treaty. However, an appeal for land rights for the purposes of maintaining a distinct Ojibway culture is essentially a moral claim, the effectiveness of which has been limited in the past.

\footnotetext{
2 In Jourdain, 9 and Wilson in Public Hearings Volume 2. Toronto Hearings, 86, respectively.
} 
Moreover, as discussed by Noel Dyck, such a strategy is to some extent a response to a new form of coercive tutelage. Dyck proposed that assimilation policy has in many ways been replaced by an insistence on Aboriginal adherence to a romanticized ideal of their "traditions" in order to be seen as legitimate. He suggests that this is leading to a situation in which Aboriginal leaders are increasingly appealing to this ideal, and that this is a reflection of the very limited options they have for political leverage. ${ }^{3}$ This argument usefully explores the emergence of new federal strategies, but I believe that it over-simplifies the relationship between federal bureaucrats and Aboriginal leaders. While it is certainly true that Aboriginal leaders have limited political resources, in the Quetico they have been able to employ a variety of framing strategies and other tactics of resistance to federal and provincial attempts to alienate them from their land. Dyck argues that cultural conservatism is a common strategy of contemporary Aboriginal leaders to attempt to make a moral case for Aboriginal rights, appealing to a romanticized view of Aboriginal traditional culture. This does not, however, take into account the idea that, as former Teme-Augama Anishnabai Chief James Twain expresses it:

Knowing who you are and where you belong makes you a better person. You will possess self-esteem and a feeling of belonging to our lands, to Mother Earth. That has been what has made us strong- as a people and as a nation. ${ }^{4}$

Ojibway leaders might have had any number of reasons for turning away from public statements on the importance of their distinct culture in the century between 1873 and 1971. Not least among the likely possibilities is that they recognized the disdain expressed by federal and provincial government officials for their traditions.

\footnotetext{
Dyck, 149-151

4 Twain in Bruce Hodgins, Ute Lischke and David T. McNab, Blockades and Resistance: Studies in Actions of Peace and the Temagami Blockades of 1988-89, (Waterloo:Wilfred Laurier University Press, 2003), 15.
} 
Internalization of this racist perception has been well-documented, in particular by the Royal Commission on Aboriginal Peoples. ${ }^{5}$ From this perspective, the re-emergence of arguments for the value of Ojibway culture represent a powerful example of Ngugi's "decolonizing the mind," rather than a reaction to a change in the form of federal tutelage.

In some cases, arguments Ojibway leaders may have made regarding the connection between their land and their culture may simply not have been recorded. One example of this is the case discussed in Chapter Three in which the record of Chief Mawedopenais' speech about the Ojibway relationship to the land appears to be incomplete. ${ }^{6}$ Furthermore, Ontario made it very clear in the St. Catherine's Milling case that an argument that was "simply moral and no more" was not worthy of serious consideration. In 1971, when Willy Wilson spoke at the public hearings on behalf of the Ojibway, it was not him but the committee, representing an educated, white segment of the public of Ontario, who raised the issue of a spiritual connection to the land. Dyck acknowledges that "the paternalistic and racist assumptions that for so long guided Canada's treatment of Indian communities are no longer fashionable within federal government circles, ${ }^{17}$ and that Aboriginal leaders have used this history to embarrass the government into action on several occasions.

\footnotetext{
This argument is clearly introduced in Ponting, 117-125 and related to the solutions offered by the RCAP report in Ponting, 445-470.

6 See chapter three, page 37 and Morris, 59.

7 Dyck, 142
} 


\section{Contesting political representivity}

The question of representivity has frequently emerged as a key issue of politics in the Quetico. ${ }^{8}$ Whenever Ojibway leaders become a serious challenge to government, the immediate response is to question and ultimately deny their authority as legitimate representatives of their constituents. This strategy was used by the Commissioners in the negotiation of the treaty to undermine Chief Blackstone and has recently re-emerged in the federal response to Grand Chief Leon Jourdain's criticisms of the FNGA. The Ojibway have also used this strategy: Chief Blackstone questioned the authority of the Commissioners and Grand Chief Jourdain has rejected the authority of Minister Nault. In both cases, federal rejection of Ojibway authority was a direct response to an Ojibway rejection of federal authority. Thus, although the argument about representivity was introduced by Weaver and Beckett to explore a governmental strategy to undermine Aboriginal leadership, in the Quetico at least it seems to have been used as a response to Ojibway challenges to the legitimacy of colonial authority. It can also be considered as one aspect of the larger government strategy of suppression.

\section{Suppression and the colonial discourse}

The discussion of governmental strategies in Chapter Four reveals the importance of the suppression of alternative viewpoints, as postcolonial theorists would predict. Suppression can range from the incomplete record of a speech at the treaty negotiations, as was likely the case when Mawedopenais spoke of the Ojibway relationship with the land, to the under-reporting of population numbers, as is likely at Sturgeon Lake, to the

8 As the concept is discussed in Weaver. 
obscuring of Ojibway history in official reports, as in the 1977 Master Plan. Non-textual examples include the removal of the requirement for band council consent to land sales in 1898 , the request that evidence of Ojibway traplines be concealed from the public in the 1970 's, and the cut-off of negotiations on self-governance in 2002. Suppression as a framing strategy may not have been explicitly considered by Snow et al because it requires political power and access to media. For suppression to work, a leader must have the capacity to overpower dissenting voices much of the time. This is clearly difficult for many protest movements, the subject of the Snow et al. study. For government, however, it is clearly a crucial aspect of the development of the colonial discourse. In the Quetico, suppression has been used by the federal government to betray its fiduciary obligation to the Ojibway in the negotiations of reserve lands in 1913 and by the Ontario government in the inscription of the land as Quetico Provincial Park.

Suppression, however, is also a risky strategy for government to employ. In modern capitalist democratic states, the legitimacy of government authority rests on the image of public consent, compromising the state's capacity to employ repressive tactics. In fact, the use of repressive tactics against state citizens can be characterized as a failure of democracy, and many protest movements have framed it in just this way. ${ }^{9}$ While this has not historically been a tactic employed by Ojibway leaders in the region, it can be seen in the recent actions by Grand Chief Jourdain, in particular his vocal protests against the FNGA in Minister Nault's riding and his support for the road blockades in Grassy Narrows. It can be interpreted as an extension of the Ojibway tradition of demanding recognition of past injustices before considering new decisions. This insistence on

9 The recent wave of anti-globalization protests is perhaps the clearest example, with the popular chant of "This is what democracy looks like" being used in response to riot police and tear gas. 
incorporating an historical perspective has been seen in the treaty negotiations, when the chiefs repeatedly demanded reparations for previous incursions onto their lands. It appeared in the 1885 letter protesting log driving through a reserve and referring to the fact that "[the] last time we was promised something we never got [it]."10 Again in 1971, the brief prepared for the park hearings referred to having been "sold down the river for a mess of pottage,"11 among other colourful descriptions.

\section{Continuity and change}

This study reveals a subtle process of articulation at work in Ojibway-government relations in the Quetico region. There are many consistent elements in both government and Ojibway negotiation strategies. The use of humour, the insistence on an historical perspective, and the use of direct confrontation when indirect communication has failed have been elements of Ojibway negotiations throughout the period. The federal government has repeatedly challenged the representivity of Ojibway leaders and refused to discuss the past in negotiations, including not only the treaty process but the Sturgeon Lake land claim and the recent self-governance negotiations. The Ontario government has denied Ojibway land rights, suppressed Ojibway history, and framed Ojibway needs as a purely federal concern.

Changes in negotiation and resistance strategies have emerged in situations when existing tactics have proven unsuccessful. For this reason, there are more evident changes in Ojibway strategies than in those of government. The Ojibway used strategies

\footnotetext{
10 Letter forwarded by J.N Pither, Indian Agent to George McPherson, Indian Agent, April 6, 1885, L, NAC RG10-C-VI Outgoing Correspondence

1 "Brief, Rainy River Indians," in Public Hearings, Volume 1, 4.
} 
of direct confrontation and expressions of cultural confidence in early treaty negotiations, but in the period between 1873 and 1970 there were very few such incidents. This period saw a traumatic loss of land and political power, coupled with the imposition of assimilation policy. Ojibway leaders found very few avenues to express their needs and concerns. With the resurgence of Aboriginal politics across Canada in the 1970's, Ojibway leadership began to gain access to the media and the settler public, as seen in the 1971 public hearings, the 1991 apology to the Sturgeon Lake band, and the recent protests against the FNGA and the logging of Grassy Narrows territory. Cultural confidence is more apparent and is being used effectively to oppose government ideology. Ojibway leaders have also changed their strategic appeals to settler values. The chiefs at the treaty negotiations appealed to honesty and the recognition of their land rights. This argument was based on a moral claim to the land as a gift from the Creator, implying that it would be greedy and dishonest to appropriate it for settlers who had their own land elsewhere. At the 1971 hearings, in contrast, Wilson and the chiefs he represented amplified the values of justice, equality and charity. More recently, Grand Chief Jourdain has returned to the language of rights, but this is now framed in terms of legal rights, rather than solely as a moral claim. The ethical basis of contemporary claims is based largely on demands for recognition of past injustices.

Government use of value amplification has been refined over the past century, but it has essentially changed very little. Nineteenth century appeals for order were fairly explicit in their demonization of Aboriginal culture, but as this has grown less acceptable to the settler public, new language has been developed. The FNGA is framed as a means of creating democracy and honest government, for example, but it carries on the 
nineteenth century project of eliminating traditional forms of Aboriginal governance. Ontario has moved away from its earlier denial of Ojibway history, rights and grievances, but it has continued to deny its own responsibilities with regard to both the past and the future of land use. This is demonstrated both in the 1991 apology to the people of Lac La Croix and Sturgeon Lake, which blamed the federal government for actions which were in many cases taken by the province, and also in the current conflict over Grassy Narrows, which involves a provincially-licensed logging company.

These shifts demonstrate that Ojibway strategies to defend their land and governance rights have had some effects, but it also emphasizes the limited capacity of language in the practice of resistance. In many areas, in particular in discussions with the federal government, Ojibway have been unsuccessful. The chiefs in 1873 were not able to obtain reparations for the construction and use of the Dawson Road, the Sturgeon Lake band was unable to change its reserve, the Grand Council was unrecognized for many years and continues to be marginalized, and the Sturgeon Lake land claim was effectively ignored. Suppression remains the most important government tactic, and it is the key starting point for any form of resistance. It is a powerful tool for the maintenance of state governance and authority, denying the possibility of alternative practices and symbols. It is never completely successful, however. The Ojibway have often effectively used language and symbolism to shift the frame of discussions and denaturalize the colonial discourse. They have succeeded in forcing negotiations on some issues the federal and provincial governments hoped to suppress entirely, such as reparations for the forced removals of Sturgeon Lake band members, the use of traplines and motorized boats, and the construction of a road to the Lac La Croix reserve. Quetico 
Provincial Park includes many symbols of Ojibway resistance, from the traplines and motorboats to the removal of images of pictographs from the Quetico Foundation website. Beyond the physical boundaries of the park, the recent protests in Kenora and the road blockades at Grassy Narrows are evidence of the continuing presence of Ojibway resistance. State control of the Quetico and its people is clearly contested on many levels, both practically and symbolically. 


\section{SOURCES CONSULTED}

\section{Books and Articles}

Abel, Kerry and Jean Friesen, eds. Aboriginal Resource Use in Canada: Historical and Legal Aspects. Winnipeg: University of Manitoba Press, 1991.

Asch, Michael, ed. Aboriginal and Treaty Rights in Canada: Essays on Law, Equality and Respect for Difference. Vancouver: University of British Columbia Press, 1997.

Ashcroft, Bill, Gareth Griffiths and Helen Tiffin. The Empire Writes Back: Theory and Practice in Post-colonial Literatures. London: Routledge, 1989.

Battiste, Marie, ed. Reclaiming Indigenous Voice and Vision. Vancouver: University of British Columbia Press, 2000.

Bell, Catherine and Michael Asch. "Challenging Assumptions: The Impact of Precedent in Aboriginal Rights Litigation." In Aboriginal and Treaty Rights in Canada: Essays on Law, Equality and Respect for Difference, ed. Michael Asch, 38-74. Vancouver: University of British Columbia Press, 1997.

Berger, John. Ways of Seeing. London: British Broadcasting Corporation and Penguin Books, 1972.

Black-Rogers, Mary. "Varieties of 'Starving': Semantics and Survival in the Subarctic Fur Trade 1750-1850." Ethnohistory Vol 33:4 (1986): 352-383.

Brody, Hugh. Maps and Dreams: Indians and the British Columbia Frontier. Vancouver: Douglas \& McIntyre, 1988.

Brown, Jennifer S.H. And Elizabeth Vibert, eds. Reading Beyond Words: Contexts for Native History. Peterborough, ON: Broadview Press, 1996.

Coatsworth, Emerson. The Indians of the Quetico. Toronto: Quetico Foundation, 1957.

Chamberlin, J. Edward. "Culture and Anarchy in Indian Country." In Aboriginal and Treaty Rights in Canada, ed. Michael Asch, 3-37. Vancouver: University of British Columbia Press, 1997. 
Chute, Janet E. The Legacy of Shingwaukonse: A Century of Native Leadership. Toronto: University of Toronto Press, 1998.

Cottam, Barry S. "The Twentieth-Century Legacy of the St. Catherine's Case: Thoughts on Aboriginal Title in the Common Law." In Co-Existence? Studies in Ontario First Nations Relations, ed. Bruce W. Hodgins, Shawn Heard and John S. Milloy. Peterborough: Frost Centre for Canadian Heritage and Development Studies, 1992.

Désy, Pierrett and Frédéric Castel. "Native Reserves of Eastern Canada to 1900." In Historical Atlas of Canada Volume II: The Land Transformed, 1800-1899, ed. R. Louis Gentilcore. Toronto: University of Toronto Press, 1993.

Dickason, Olive Patricia. Canada's First Nations: A History of Canada's Founding Peoples from Earliest Times. $3^{\text {rd }}$ ed. Toronto: Oxford University Press, 2002.

Dyck, Noel. What is the Indian "Problem": Tutelage and Resistance in Canadian Indian Administration. St. John's: Institute of Social and Economic Research, Memorial University, 1991.

Gibbons, Roger. "Historical Overview and Backgound: Part I." In First Nations in Canada, ed. J. Rick Ponting, 19-34. Toronto: McGraw Hill Ryerson, 1997.

Gill, Sam D. and Irene F. Sullivan. Dictionary of Native American Mythology. New York: Oxford University Press, 1992.

Goffman, Erving. Frame Analysis: An Essay on the Organization of Experience. Cambridge, MA: Harvard University Press, 1974.

Hansen, Thomas Blom and Finn Stepputat. States of Imagination: Ethnographic Explorations of the Postcolonial State. Durham: Duke University Press, 2001.

Henderson, James (Sákéj) Youngblood. "Postcolonial Ghost Dancing: Diagnosing European Colonialism." In Reclaiming Indigenous Voice and Vision, ed. Marie Battiste, 57-76. Vancouver: University of British Columbia Press, 2000.

Hickerson, Harold. The Chippewa and Their Neighbours: a Study in Ethnohistory. New York: Holt, Rinehart and Winston, Inc, 1970.

Hind, Henry Youle. Narrative of the Red River Exploring Expedition of 1857 and of the Assinniboine and Saskatchewan Exploring Expedition of 1858, 2 Vols. London: Longman, Green, Longman and Roberts, 1860; reprint New York: Greenwood Press, 1969. 
Hodgins, Bruce W., Ute Lischke and David T. McNab, eds. Blockades and Resistance: Studies in Actions of Peace and the Temagami Blockades of 1988-89. Waterloo: Wilfred Laurier University Press, 2003.

Hodgins, Bruce W., R. Peter Gillis and Jamie Benedickson. "The Ontario Experiments in Forest Reserves." In Changing Parks: The History, Future and Cultural Context of Parks and Heritage Landscapes, ed. John S. Marsh and Bruce W. Hodgins. Peterborough: Frost Centre for Canadian Heritage and Development Studies, 1998.

Killan, Gerald. Protected Places: a History of Ontario's Provincial Parks System. Dundurn Press: Toronto, 1993.

Loomba, Ania. Colonialism/Postcolonialism. London: Routledge, 1998.

McLeod, John. Beginning Postcolonialism. Manchester: Manchester University Press, 2000.

McNab, David. "Making a Circle of Time: the Treaty-Making Process and Aboriginal Land Rights in Ontario." In Co-Existence? Studies in Ontario-First Nations Relations, ed. Bruce W. Hodgins, Shawn Heard and John S. Milloy. Peterborough: Frost Centre for Canadian Heritage and Development Studies, 1992.

McNab, David. "'Principally Rocks and Burnt Lands': Crown Reserves and the Tragedy of the Sturgeon Lake First Nation in Northwestern Ontario." In Aboriginal Resource Use in Canada: Historical and Legal Aspects, Kerry Abel and Jean Friesen, 157-171. Winnipeg: University of Manitoba Press, 1991.

McNab, David. "The Administration of Treaty 3: The Location of the Boundaries of Treaty 3 Indian Reserves in Ontario, 1873-1915." In As Long as the Sun Shines and the Water Flows A Reader in Canadian Native Studies, ed. Ian A.L. Getty and Antoine S. Lussier. Vancouver: University of British Columbia Press, 1983.

Monmonier, Mark. How to Lie with Maps. Chicago: University of Chicago Press, 1991.

Morris, Alexander. The Treaties of Canada with the Indians. Toronto: Belfords, Clarke, 1880; reprint, Toronto: Prospero, Canadian Collection, 2000.

Nelles, H.V. The Politics of Development: Forests, Mines and Hydro-Electric Power in Ontario, 1849-1941. Toronto: MacMillan of Canada Ltd, 1974.

Ngugi wa Thiong'o. Decolonizing the Mind: The Politics of Language in African Literature. London: James Currey, 1986. 
Ponting, J. Rick, ed. First Nations in Canada: Perspectives on Opportunity, Empowerment, and Self-Determination. Toronto: McGraw-Hill Ryerson, 1997.

Ponting, J. Rick and Gladys L. Symons. "Environmental Geo-politics and the New World Order: Cree Empowerment, La Grande Baleine, and Hydro-Quebec." In First Nations in Canada, ed. J. Rick Ponting, 206-221. Toronto: McGraw-Hill Ryerson, 1997.

Razack, Sherene H. Race, Space and the Law: Unmapping a White Settler Society. Toronto: Between the Lines, 2002.

Schenck, Theresa M. "The Voice of the Crane Echoes Afar": The Socio-political Organization of the Lake Superior Ojibwa, 1640-1855. New York: Garland Publishing, Inc, 1997.

Scott, James C. Weapons of the Weak: Everyday Forms of Peasant Resistance. New Haven: Yale University Press, 1985.

Snow, David A., E. Burke Rochford, Jr., Steven K. Worden, and Robert D. Benford. "Frame alignment processes, micro-mobilization, and movement participation." American Sociological Review 51 (1986): 464-481.

Titley, E. Brian. A Narrow Vision: Duncan Campbell Scott and the Administration of Indian Affairs in Canada. Vancouver: University of British Columbia Press, 1986.

Waisberg, Leo G. and Tim E. Holzkamm. "'Their Country is Tolerably Rich in Furs': the Ojibwa Fur Trade in the Boundary Waters Region 1821-1871." In Actes du Vingt cinqième congrès des Algonquinistes, 493-513. Ottawa: Carleton University, 1994.

Waisberg, Leo G., Joan A. Lovisek and Tim E. Holzkamm. "Ojibwa Reservations as 'An Incubus Upon the Territory': The Indian Removal Policy of Ontario 1874-1982." In Papers of the twenty-seventh Algonquian Conference, 337-352. Winnipeg: University of Manitoba, 1997.

Weaver, Sally. "Political representivity and indigenous minorities in Canada and Australia." In Indigenous Peoples and the Nation-State, ed. Noel Dyck. St. John's: Memorial University of Newfoundland, 1986.

Warren, William W. History of the Ojibway Nation. Saint Paul, MN: Minnesota Historical Society 1885; reprint, Minneapolis: Ross \& Haines Inc, 1957.

Wolf, Eric R. "Facing power-old insights, new questions" in Anthropology of Politics: A Reader in Ethnography, Theory and Critique. Ed. Joan Vincent. Malden, Mass: Blackwell Publishers Ltd, 2002. 


\section{Manuscript Sources}

National Archives of Canada, Ottawa

RG 10: Indian and Northern Affairs

CO 42: Canada, Formerly British North America, Original Correspondence

\section{Web Documents, Printed Documents and Reports}

Canada. Bill C-7: First Nations Governance Act. $2^{\text {nd }}$ Session, $37^{\text {th }}$ Parliament, HC Canada. Accessed May $26^{\text {th }}, 2003$. Available from http://www.fnggpn.gc.ca/FNGA_act_e.html.

Canada. Indian and Northern Affairs Canada. "About First Nations Governance: FAQ's [report on-line]." Accessed April 10, 2003. Available from http://www.fnggpn.gc.ca/QAl_e.html

Christian Peacemaker Teams. Asubpeeschoseewagong Delegation Report November 2002 [report on-line]. Accessed May 21, 2003. Available from http://www.prairienet.org/cpt/can_ asub.php; Internet.

Grand Council Treaty \#3. "Jourdain concerned that Nault is sowing the seeds of conflict [press release May 8, 2003]." Accessed May 15, 2003. Available from www.treaty3.ca/pages/mediarelations.php.

Grand Council Treaty \#3. "Treaty \#3 Bimiiwinitisowin Omaa Akiing: Governance on our Land [report on-line]." Accessed July 12, 2002. Available from www.treaty3.ca/pages/gov_init.html

Grand Council Treaty \#3. "Where is Bimiiwinitisowin Omaa Akiing standing in relation to INAC's initiative? [report on-line]" Accessed July 12, 2002. Available from www.treaty3.ca/pages/gov_init.html

Grand Council Treaty \#3. "Treaty \#3 Grand Chief Supports Grassy Narrows Action [press release December 3, 2002]." Accessed February 4, 2003. Available from www.treaty3.ca/pages/mediarelations.php.

Grand Council Treaty \#3. "A brief history of trapping [report on-line]." Accessed July 12, 2002. Available from www.treaty3.ca/pages/trapping.html.

Grand Council Treaty \#3. "Grand Council writes off Bob Nault [press release December 11, 2002]." Accessed February 4, 2003. Available from www.treaty3.ca/pages/mediarelations.php. 
Grand Council Treaty \#3. "Infrastructures[report on-line]." Accessed July 12, 2002. Available from http://www.treaty3.ca/pages/infrastructures.html.

Internet Archive. The Quetico Foundation Website, February 17, 2001 [archival file online]. Accessed November 20, 2002. Available from

http://web.archive.org/web/20010418165017/www.queticofoundation.org/pictogr aphs.html

Internet Archive. The Quetico Foundation Website, February 2, 2001 [archival file online]. Accessed November 20, 2002. Available from

http://web.archive.org/web/20001213204100/www.queticofoundation.org/pictogr aphs.html

Jourdain, Leon. Natural Resources Revenue for Aboriginal Peoples: An Alternative to Genocide, speech to the $9^{\text {th }}$ National Forest Congress [May 1-2, 2003]. Accessed May 15, 2003. Available from http://www.turtleisland.org/front/_front.htm

Nault, Robert. "First Nations Governance Act: Message from the Minister [document online]." Accessed April 10, 2003. Available from http://gpn-fng.aincinac.gc.ca/FNGA_e.asp\#msg.

Ontario. "Indian Claims, North West Angle Treaty no. 3." In Sessional Papers Number 61, May 9, 1905. Ottawa: Canadian Library Association, microfilm.

Ontario. Legislative Assembly. Debates. 35th Parliament, 1st session, May 14-June 17, 1991.

Ontario. Ministry of Natural Resources. Quetico Provincial Park Master Plan. Toronto: Ministry of Natural Resources, 1977.

Ontario. Provincial Parks Council, Quetico Provincial Park Master Plan Review. Toronto: Ministry of Natural Resources, 1982.

Public Hearings by and Briefs to the Quetico Provincial Park Advisory Committee, 4 vols. By S.G. Hancock, Chairman. 1972.

Quetico Foundation. "Native Pictographs [document on-line]." In The Quetico Foundation Website. Accessed April 4, 2002. Available from http://www.queticofoundation.org/pictographs.html.

Report of the Quetico Provincial Park Advisory Committee. By S.G. Hancock, Chairman. 1972 
Treaty and Aboriginal Rights Research. "We Have Kept Our Part of the Treaty": The Anishinaabe Understanding of Treaty \#3 [report on-line]. 1998, accessed June 4, 2002. Available from www.landclaimsdocs.com/conferences/Quebecpdf/

GrandCouncilTreatyNo.3final.pdf.

Waisberg, Leo G. and Tim E. Holzkamm. "We have One Mind and One Mouth. It is the Decision of All of Us": Traditional Anishinaabe Governance of Treaty \#3 [report on-line]. 2001, accessed June 4, 2002. Available from www.treaty3.ca/pages/TARR.html.

\section{Media}

Globe and Mail, Toronto.

Kenora Daily Miner and News, Kenora.

Manitoban, Winnipeg.

Toronto Star. 